دور إدارة الممرفة فى تصسين خدمات التدريب

والتمهويل والتسويق فى ضوء هفهوم

\title{
ريادة الأعمىال
}

دراسة تطبيقية على جهاز تنهية المشروعات بمحافظة كفرالشيخ

$$
\begin{aligned}
& \text { د كـتـو ر } \\
& \text { هـــال صبحى البلاقاسى } \\
& \text { مدرس نظم المعلومات بالمعهر العالي للإدارة } \\
& \text { وتكنولوجيا المعلومات بكفرالشيخ لطيخ }
\end{aligned}
$$


يهذف البحث الى إيضاح الدور الذي تقوم به تقنية إدارة المعرفة من خـلال برنـامج

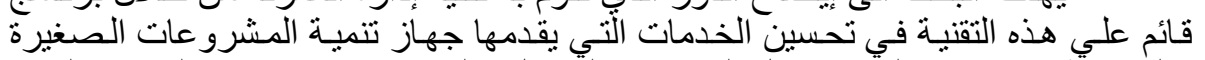

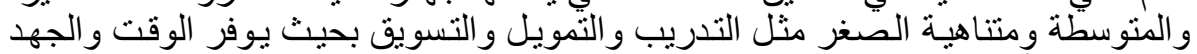

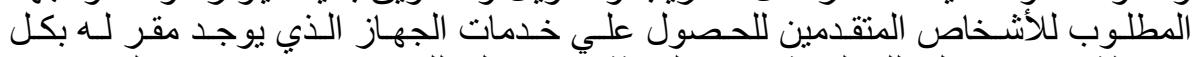

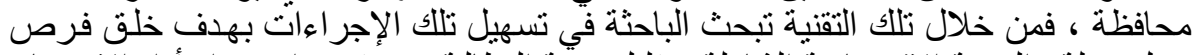

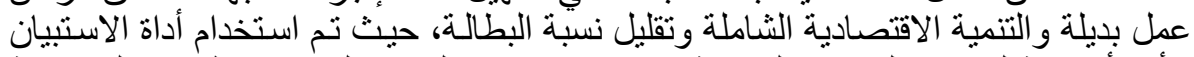

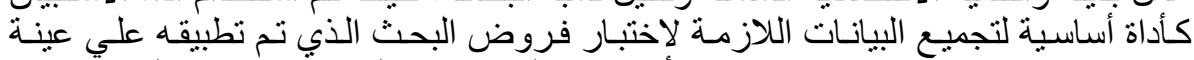

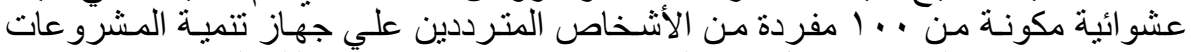

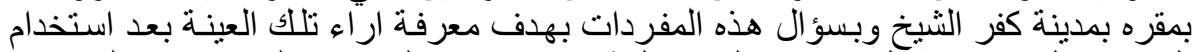

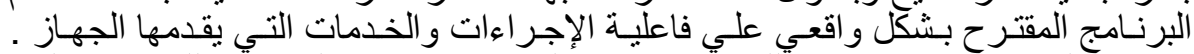

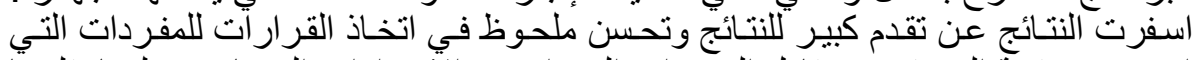

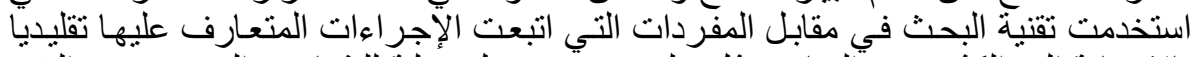

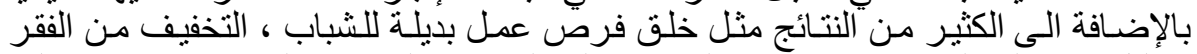

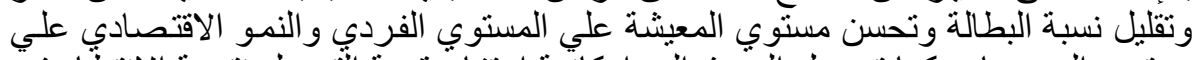

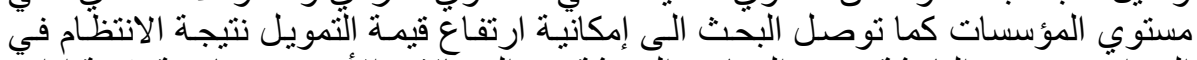

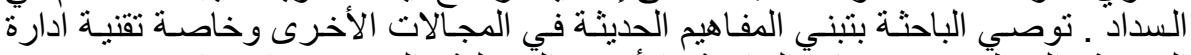

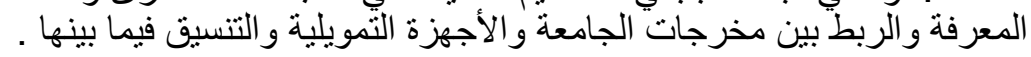

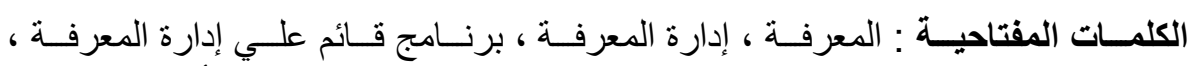
المشروعات الصغيرة ومتناهية الصغر ، جهاز تنمية المشروعات الثرة ، ريادة الأعمال .

\section{Abstract:}

The aim of the study is to study the effectiveness of knowledge management technology to improve the services provided by SME, such as training, finance and marketing, so as to save the time and effort required for people applying for the services of the device which is headquartered in each governorate. Actions to create alternative employment opportunities and overall economic development and reduce the unemployment rate. The researcher used to test the hypotheses of a questionnaire that was applied to a random sample of 100 individuals and institutions who are interested in the development of projects in its headquarters in Kafr El-Sheikh city and asked these words to know the views of this sample after using the knowledge management technology in a realistic manner to the effectiveness of the procedures and services provided by the device, The results resulted in significant progress in the results of the vocabulary used in the research technique compared to the vocabulary that followed traditional procedures in addition to many results such as creating alternative employment opportunities for youth, alleviating poverty And reduce the unemployment rate and improve the standard of living at the individual level and economic growth at the level of institutions and research has the potential to increase the value of funding due to regular payment, the researcher recommends adopting modern concepts in other areas .

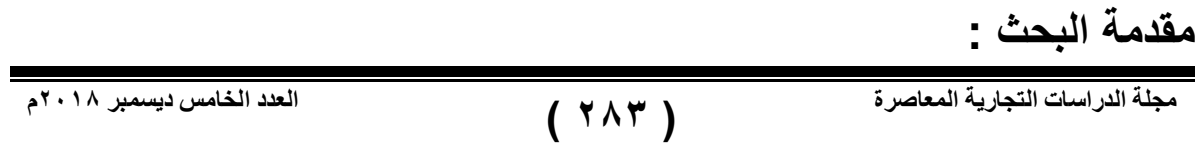




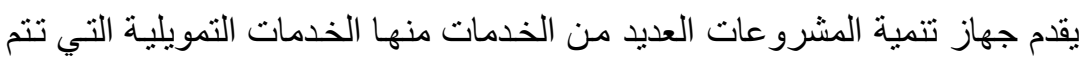

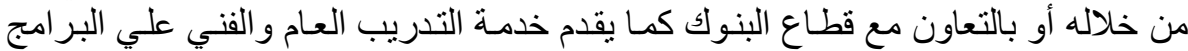

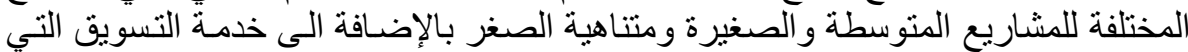

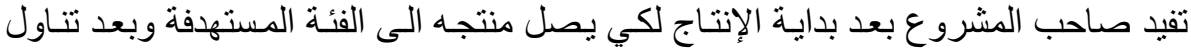

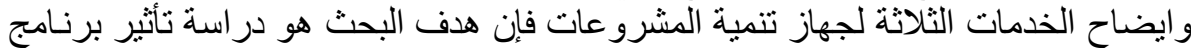

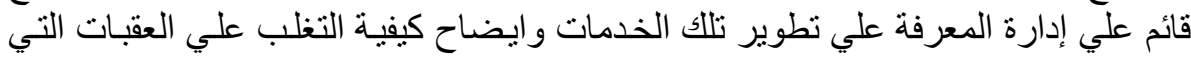

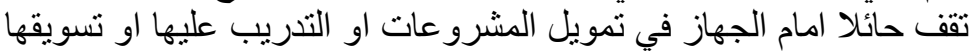

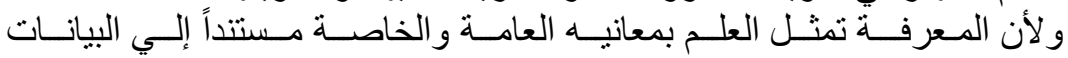

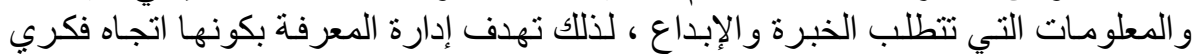

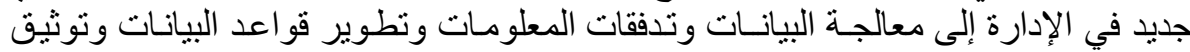

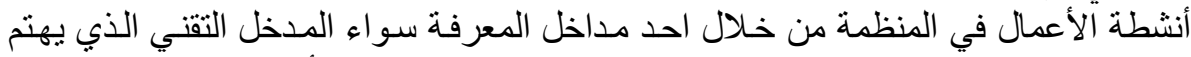

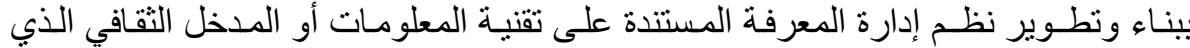

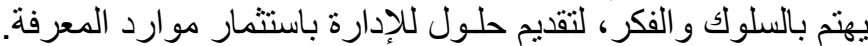

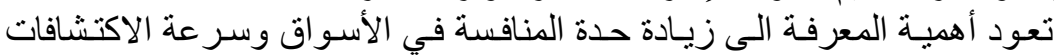

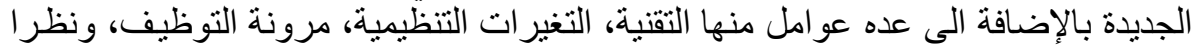

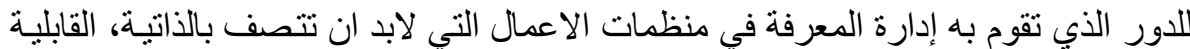

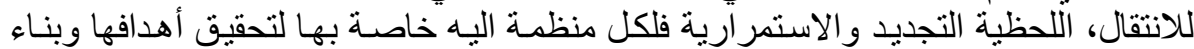

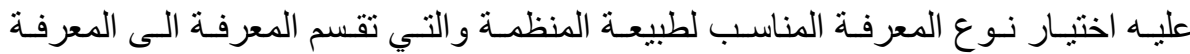

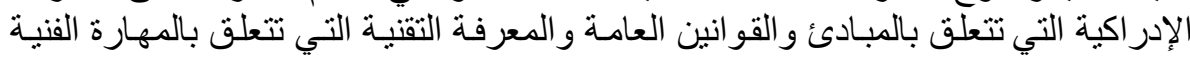

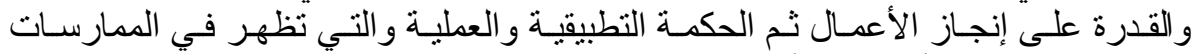

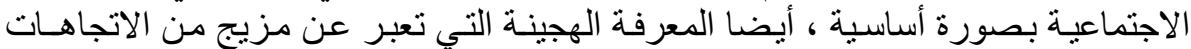

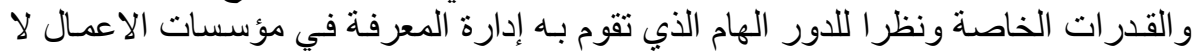

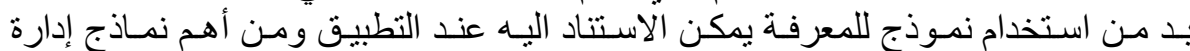

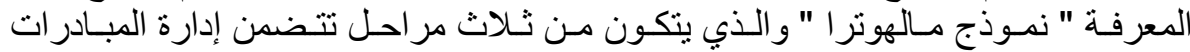

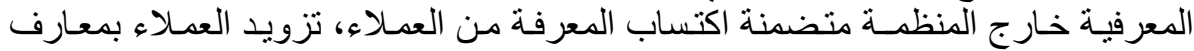

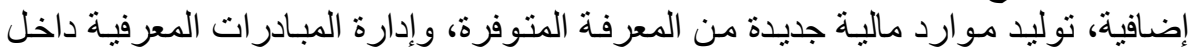

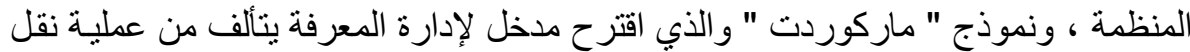

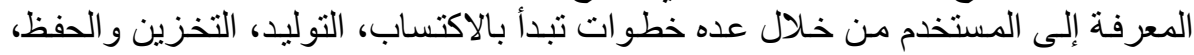

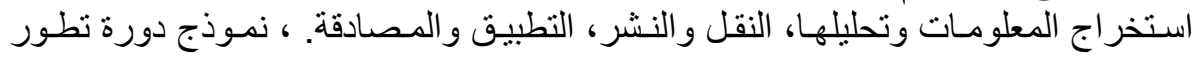

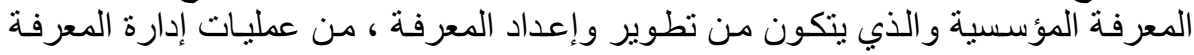

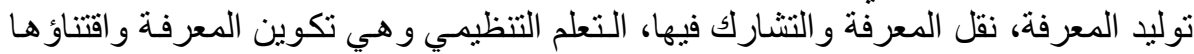

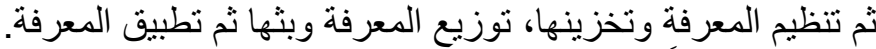

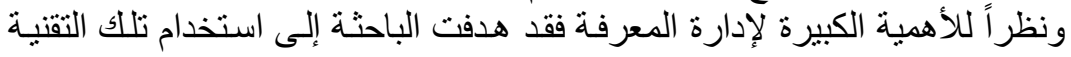

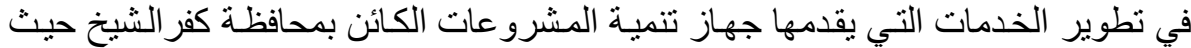

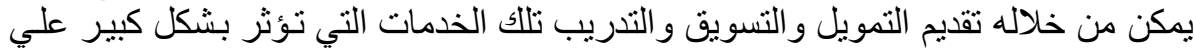

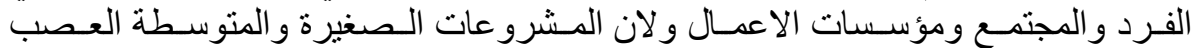

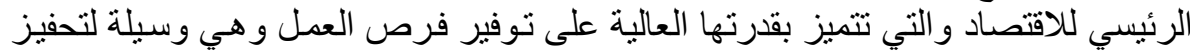

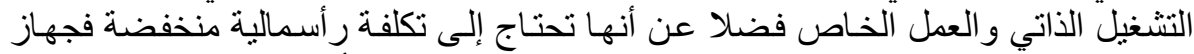

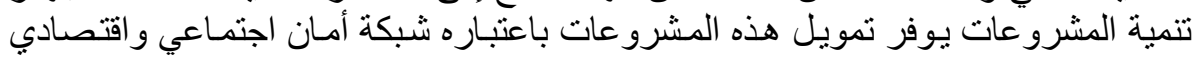

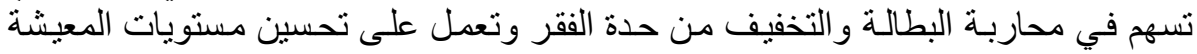

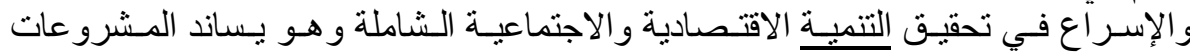

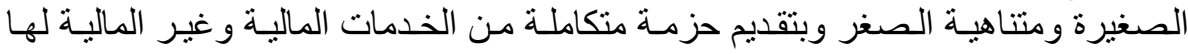


وبالتنسيق مـع كل الأطر يمكن لجهاز تتمية المشرو عات معالجـة الآثار الجانبيـة لبرنـامج

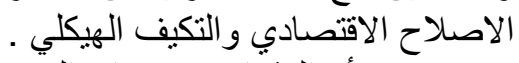

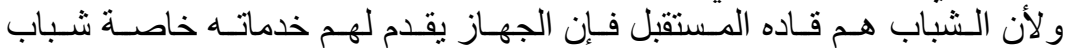

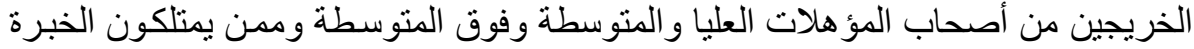

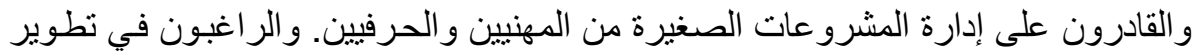

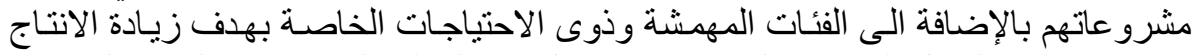

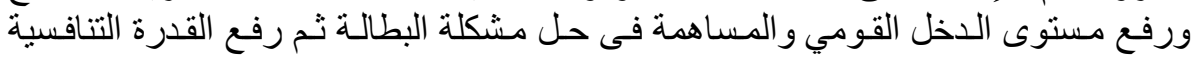

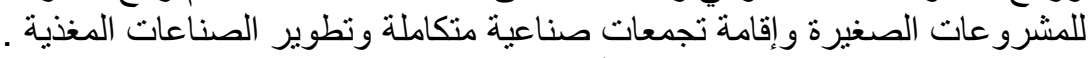

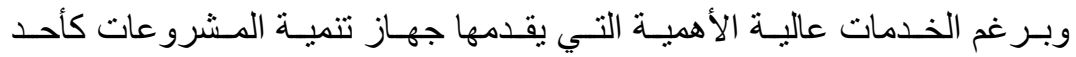

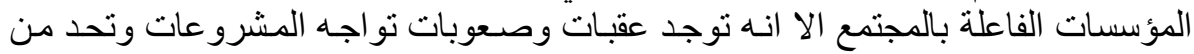

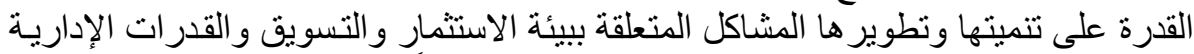

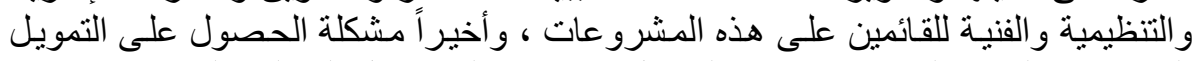

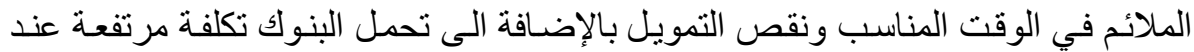

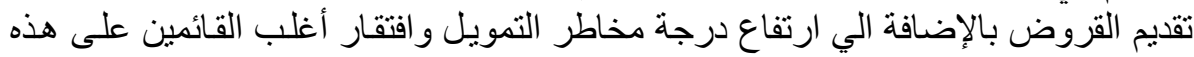

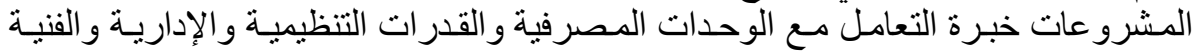

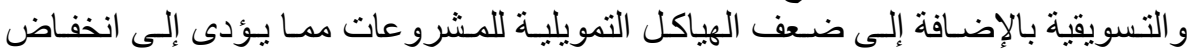

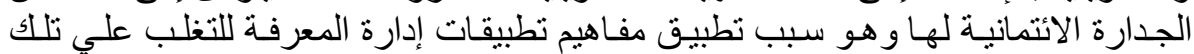

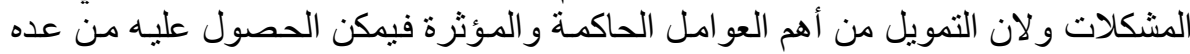

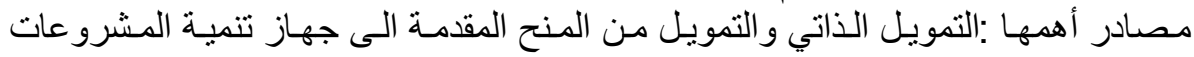

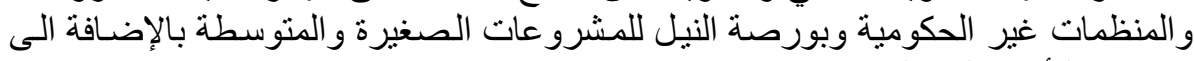

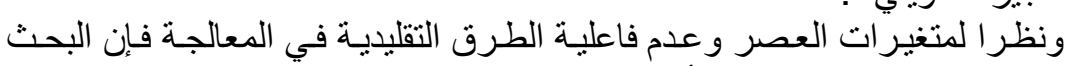

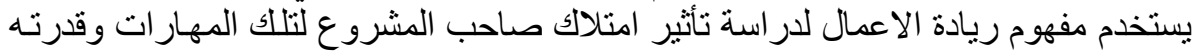

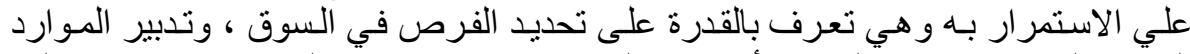

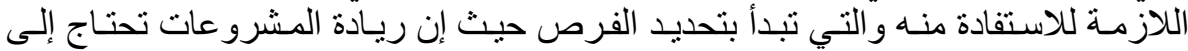

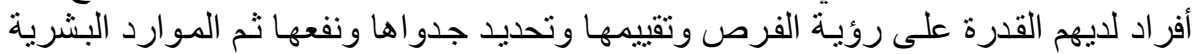

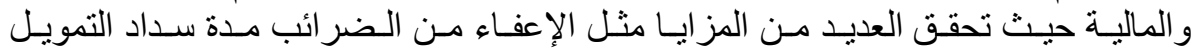

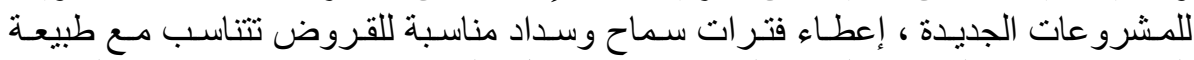

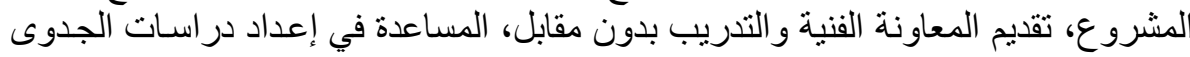

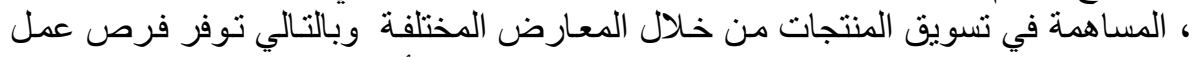
جديدة وتخفف العبء الملقي علي كاهل الدولة في ممارسة الأنشطة الاقتصادية .

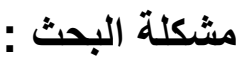
يمكن صياغة مشكلة البحث في السؤال التالي :

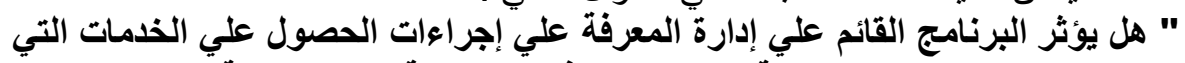

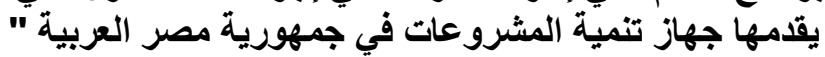

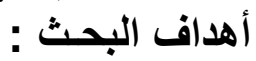

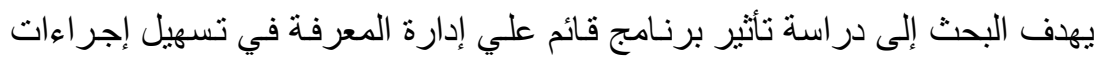

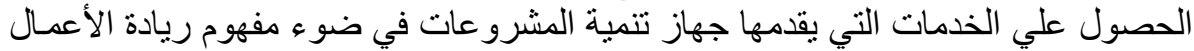

أهمية البحث ودوافعه :

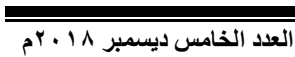

$(r \wedge \bullet)$

مجلة الاراسات التجارية المعاصرة 


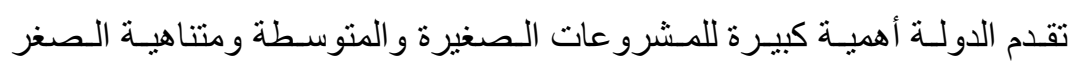

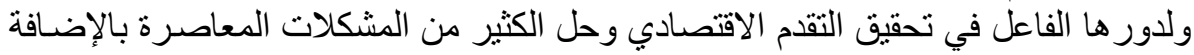

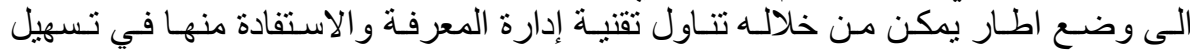

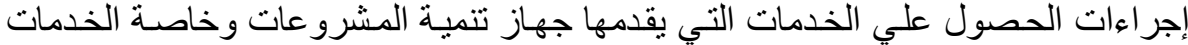
التمويلية والتسويقية .

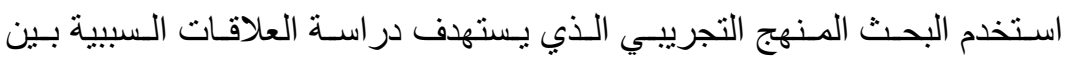

\section{منهج البحث :}

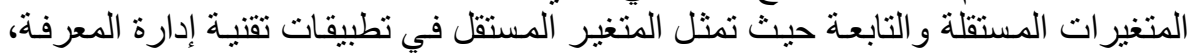

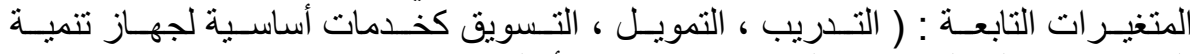

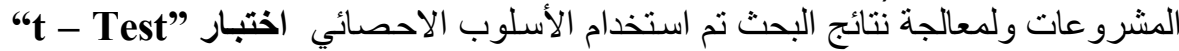
نسب الكسب المعدلة لـ "بليك" "Blacked Modified Gain Ratio" لكونهما الأكثر

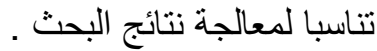

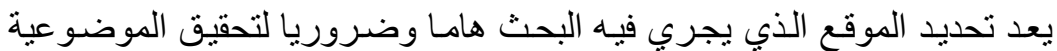

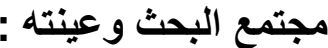

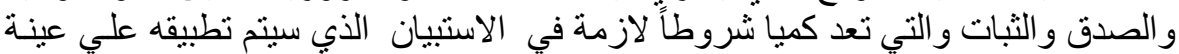

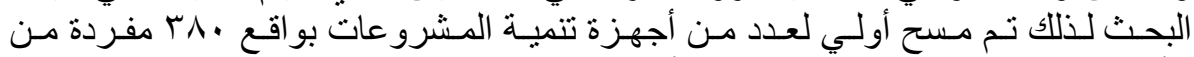

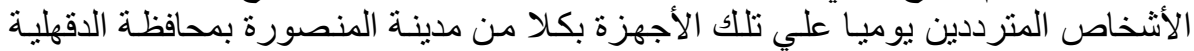

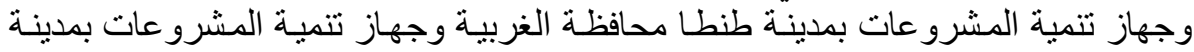

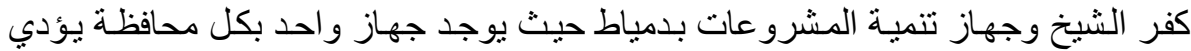

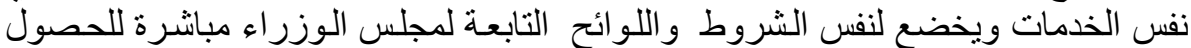

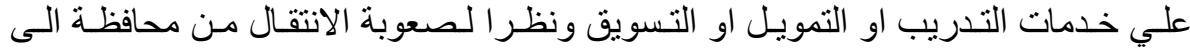

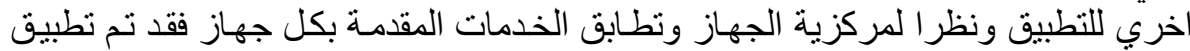

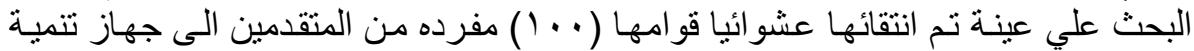

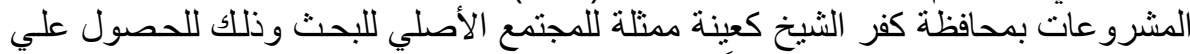

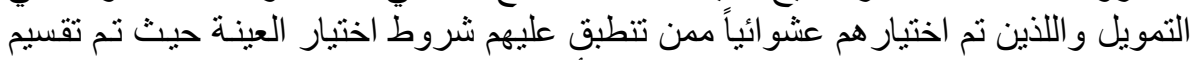

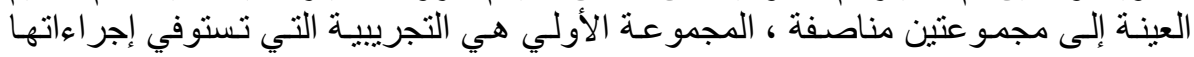

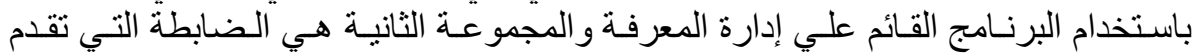

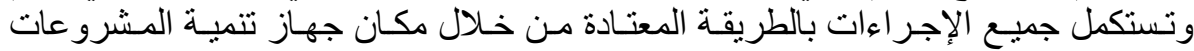

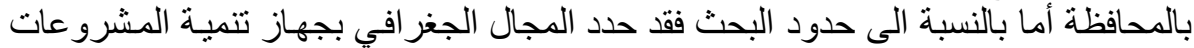

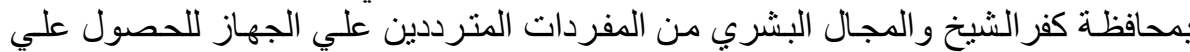

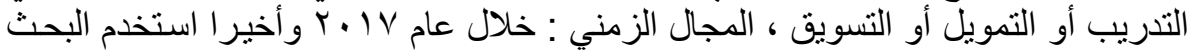

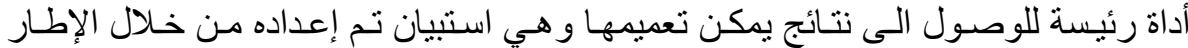
النظري للبحث ومتطلباته .

\section{الاراسات السابقة التى تناولت موضوع البحث :}

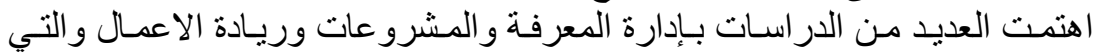

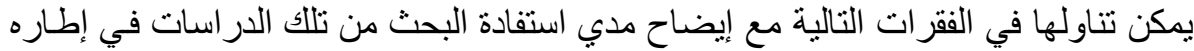

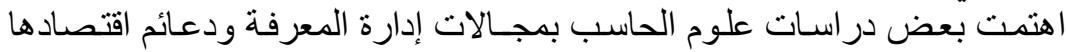

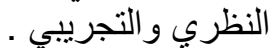

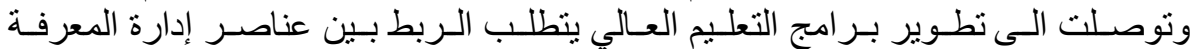

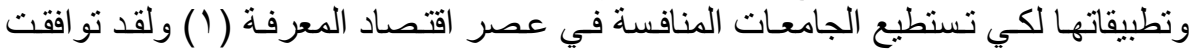




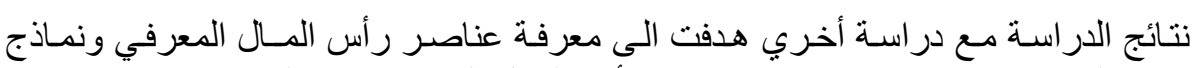

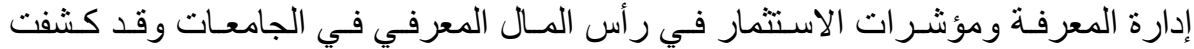

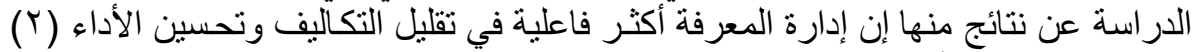

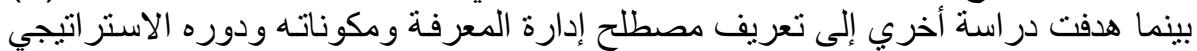

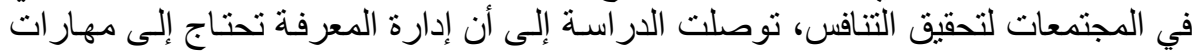

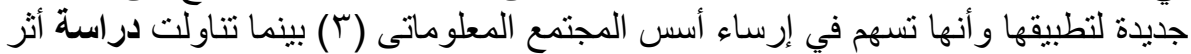

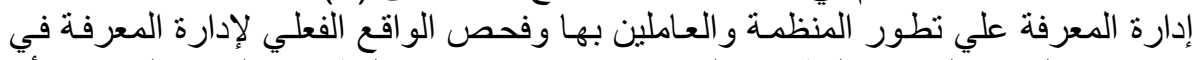

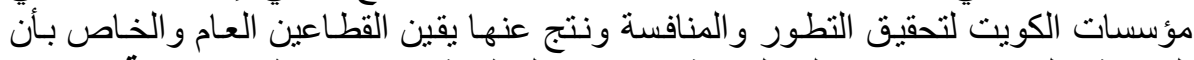

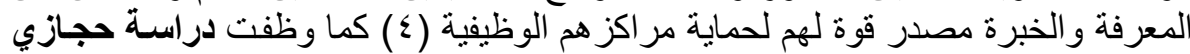

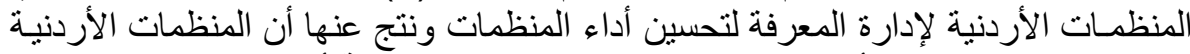

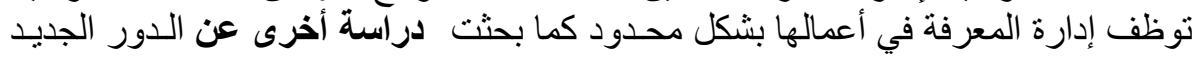

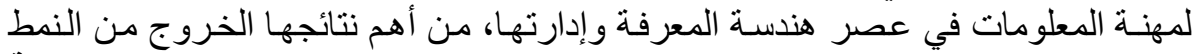

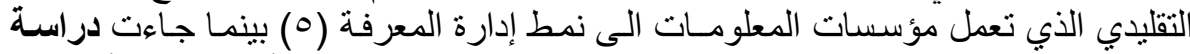

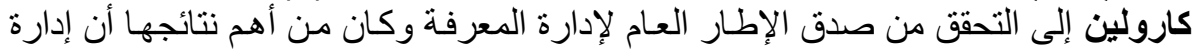

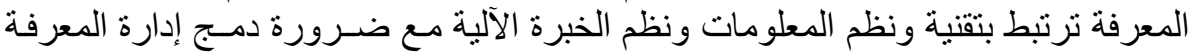
في التخصصات الأكاديمية في الجامعات الترات

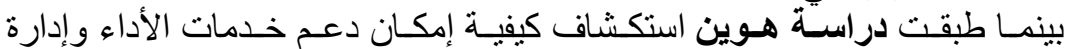

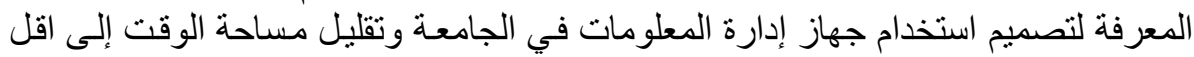

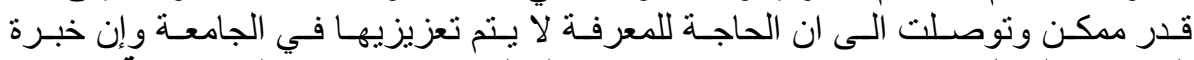

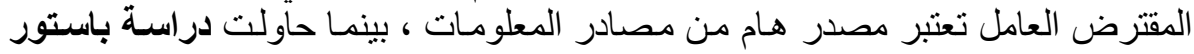

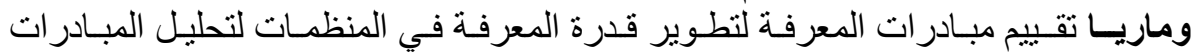

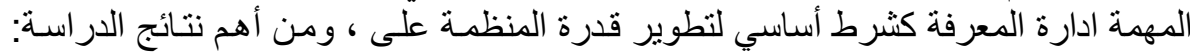

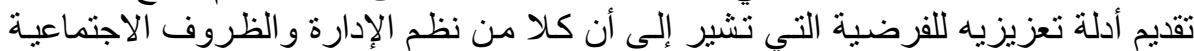

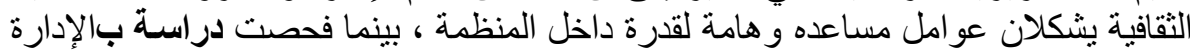

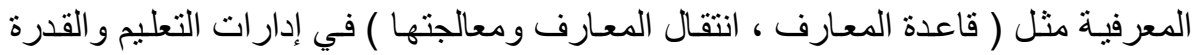

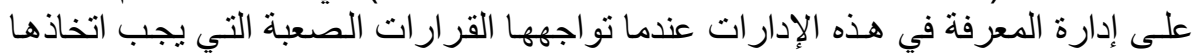

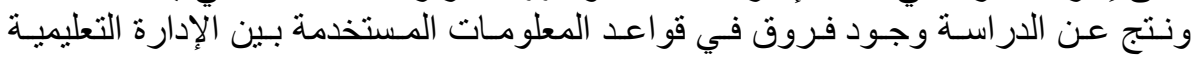

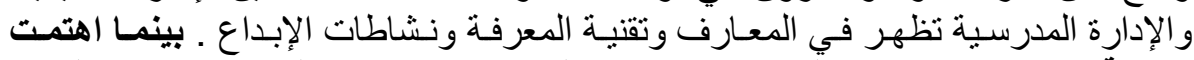

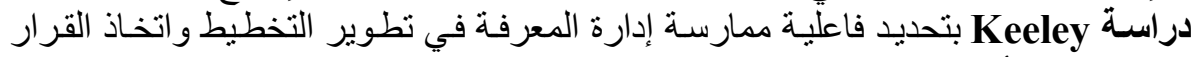

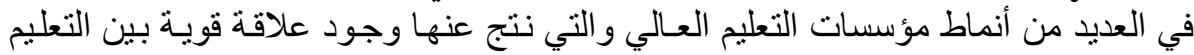

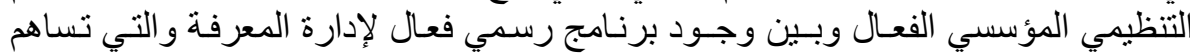

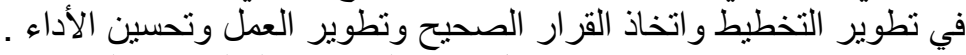

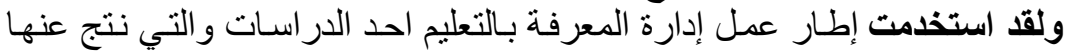

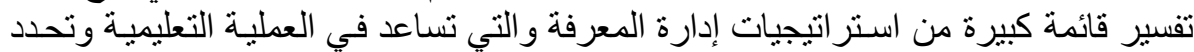

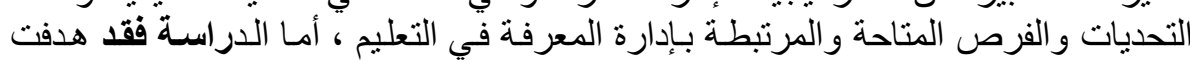

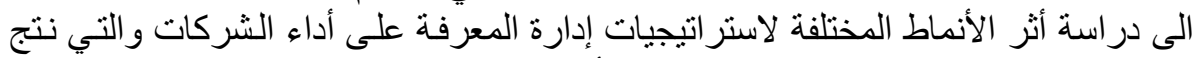

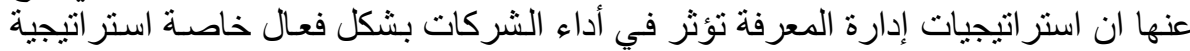

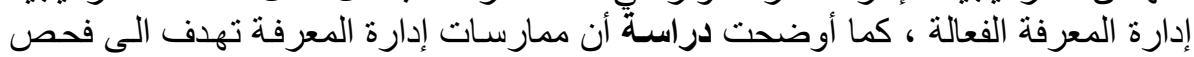

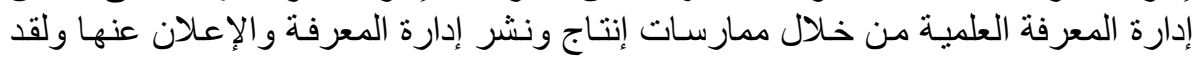

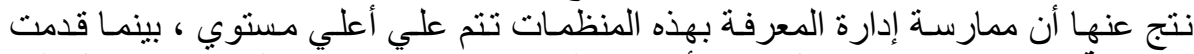

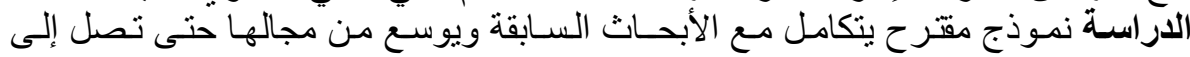

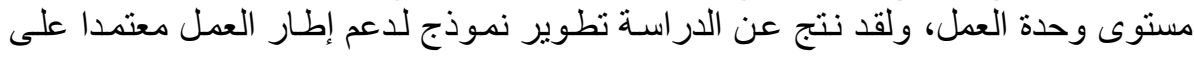




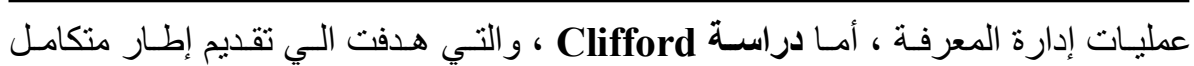

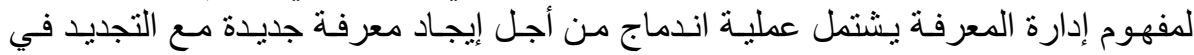

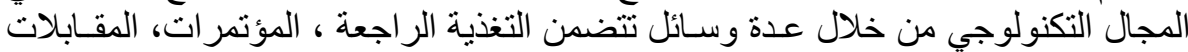

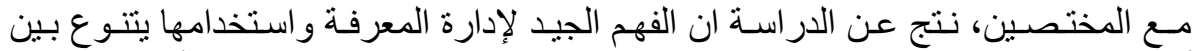

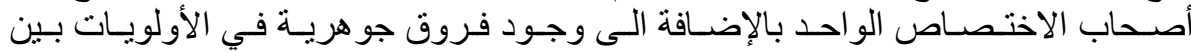

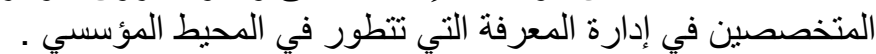

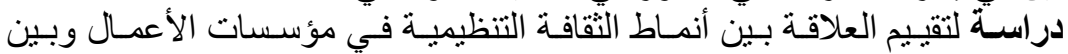

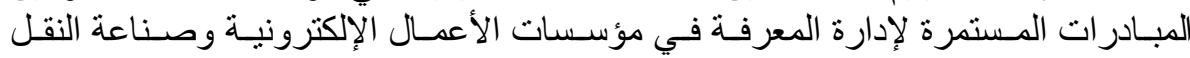

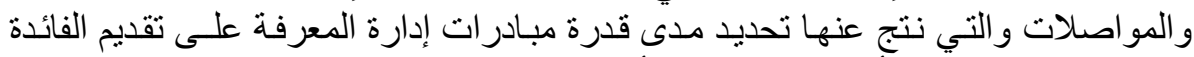

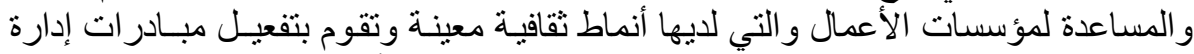

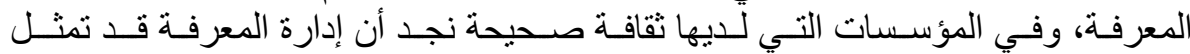

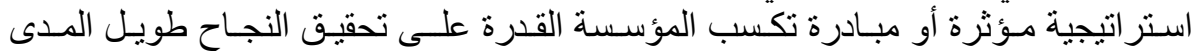

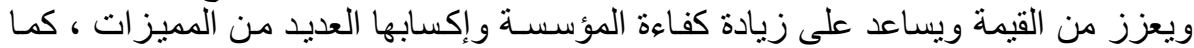

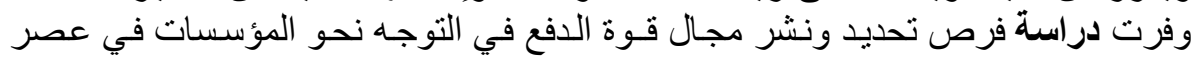

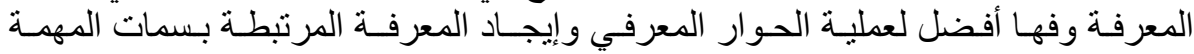

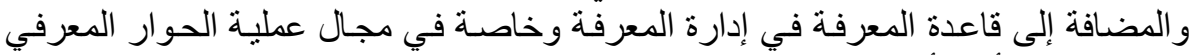

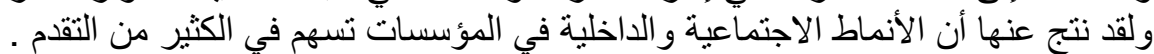

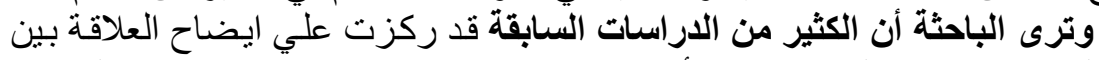

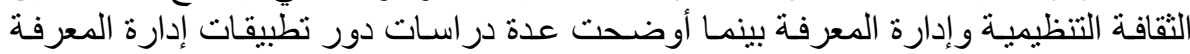

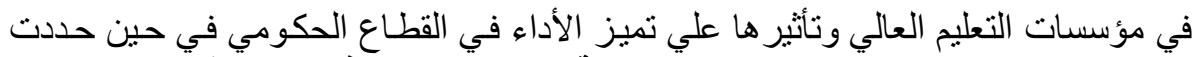

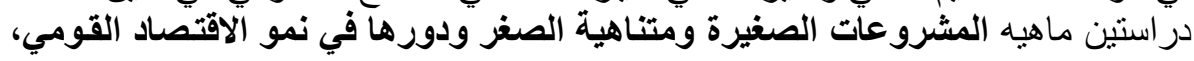

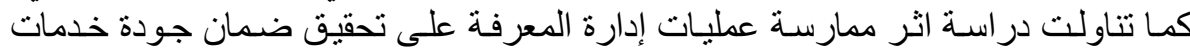

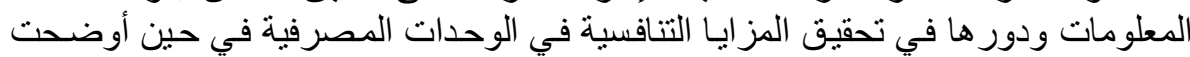

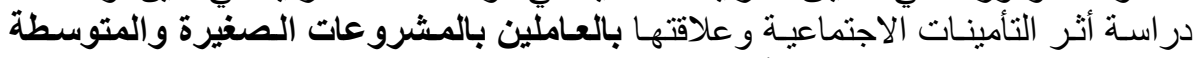

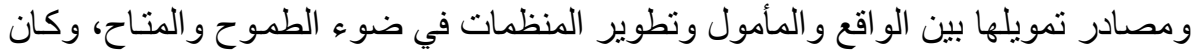

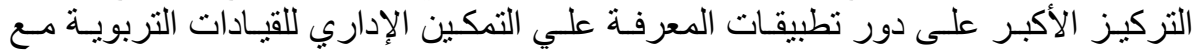

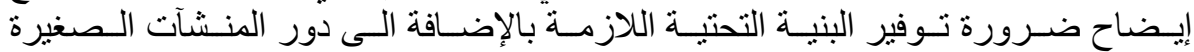

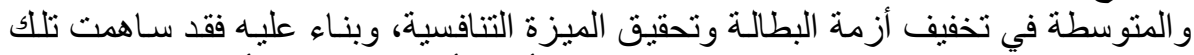

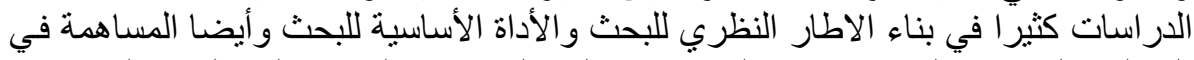

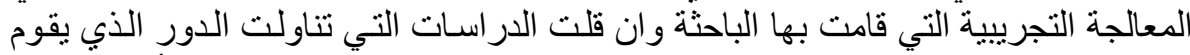

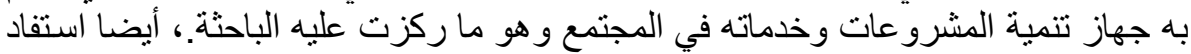

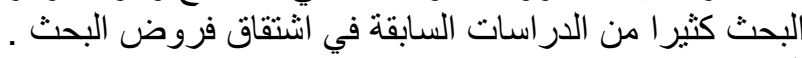

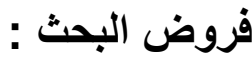

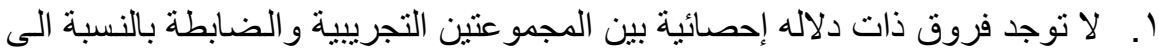

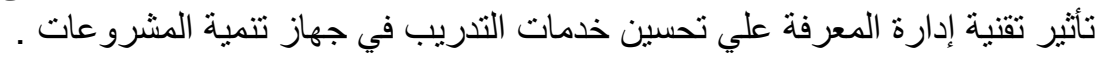

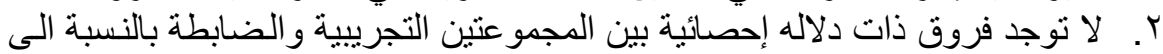

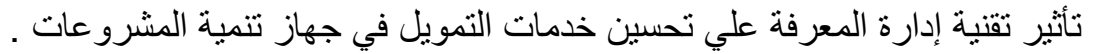

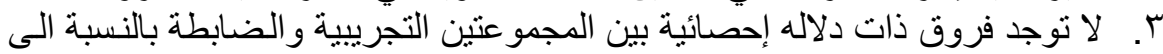

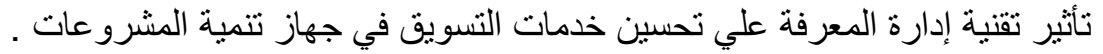

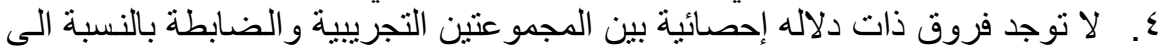

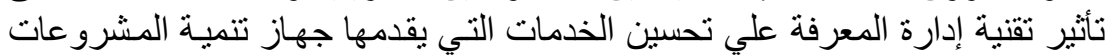




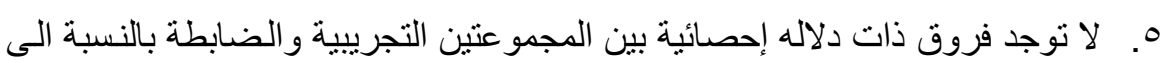
تأثثير ريادة الأعمال علي تحسين خدمات جهاز تنمية المشرو عات التينة .

\section{الإطار النظرى للبحث :}

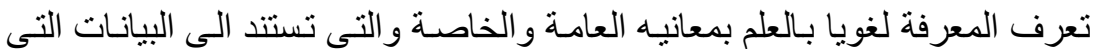

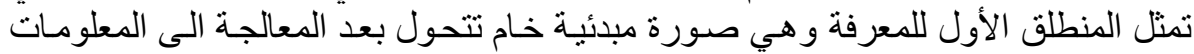

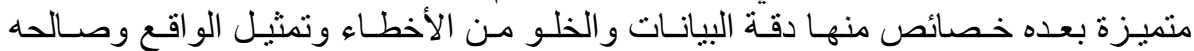

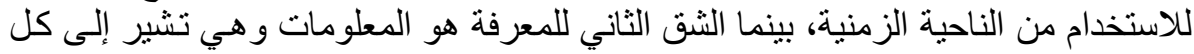

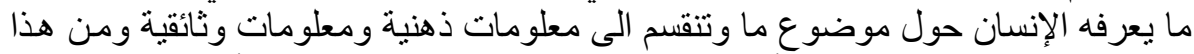

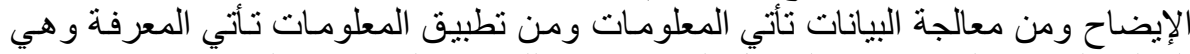

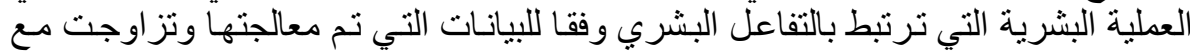

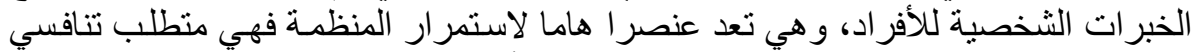

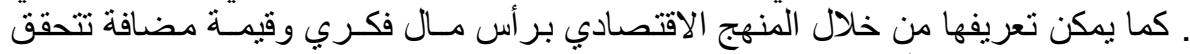

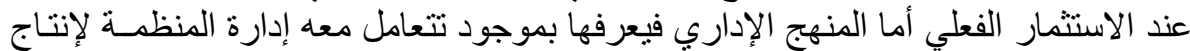

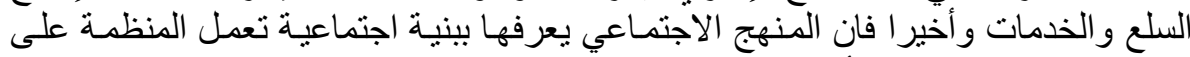

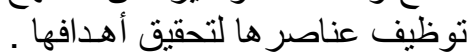

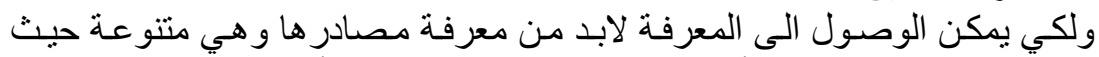

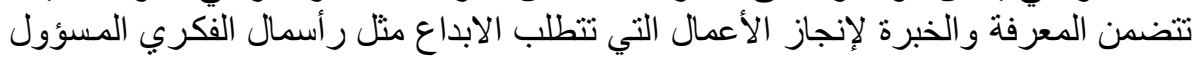

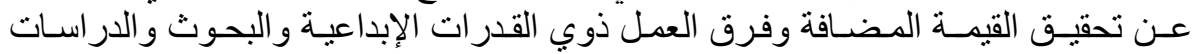

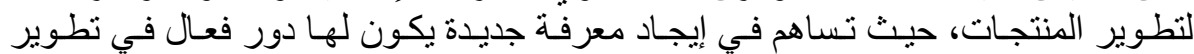

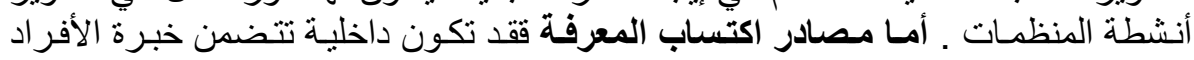

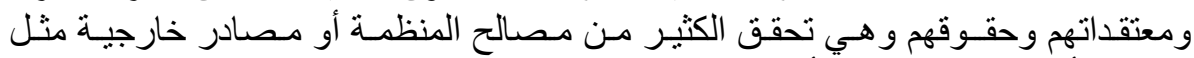

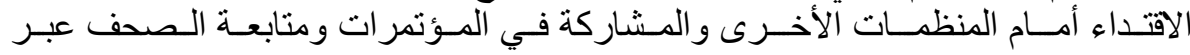

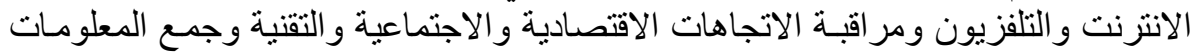

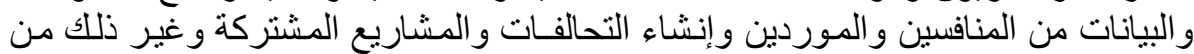

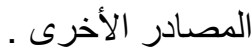

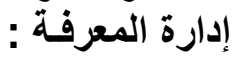

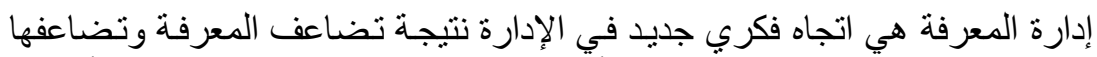

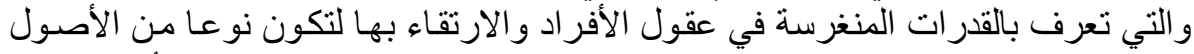

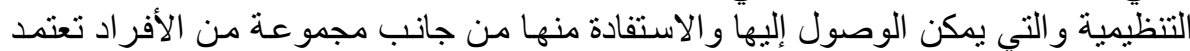

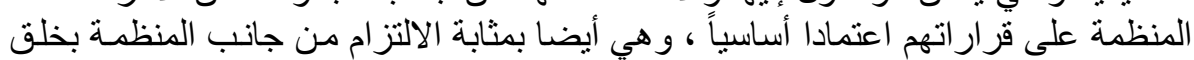

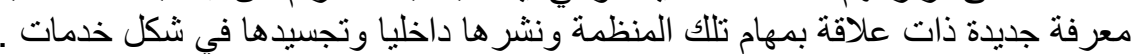

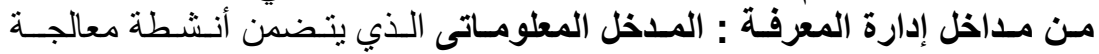

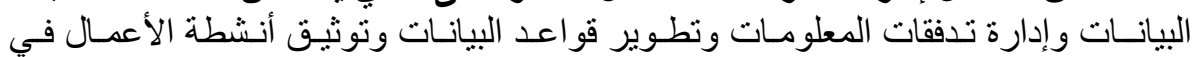

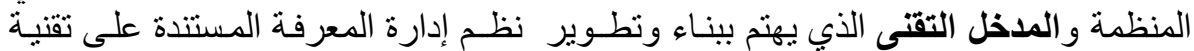

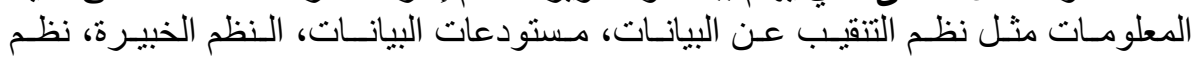

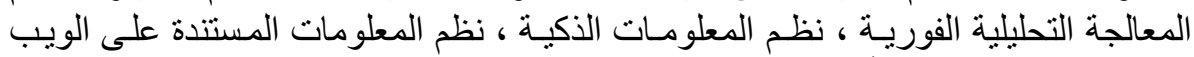

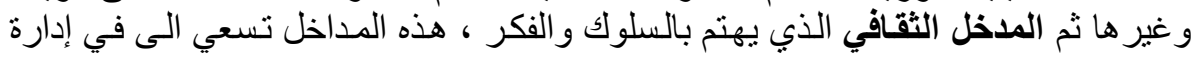

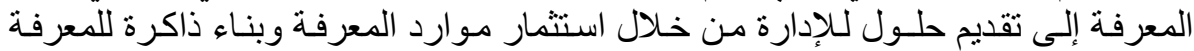

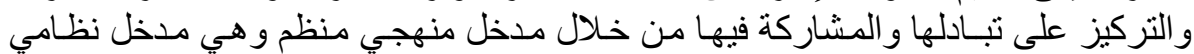

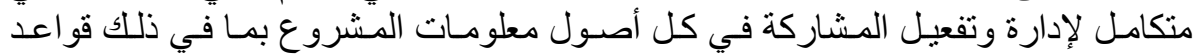

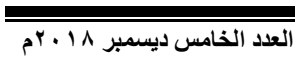


البيانـات، الوثنائق، السياسات والإجـر اءات بالإضـافة إلى تجـارب وخبر ات سـابقة يحملهـا

تعود أهميـة المعرفة الى زيـادة حدة المنافسة في الأسـواق وسـر عة الاكتشافات

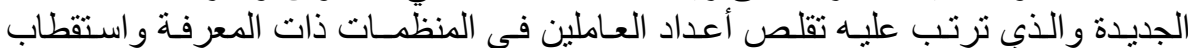

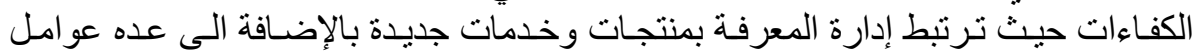

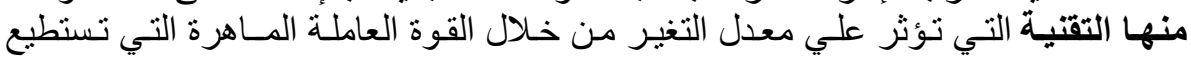

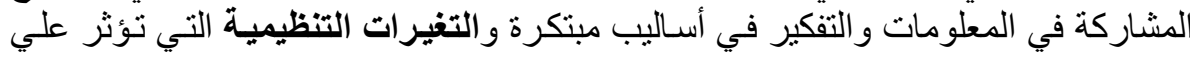

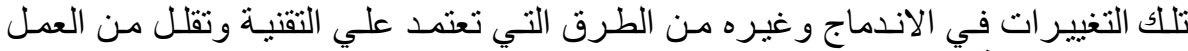

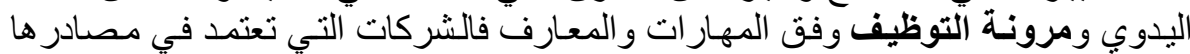

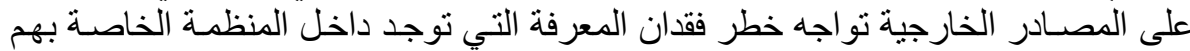

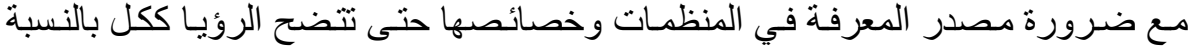

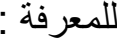

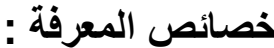

تمتلك تقنية المعرفة عددا من الخصائص التي تمثل أساسا لتطوير مؤسسات الأعمال

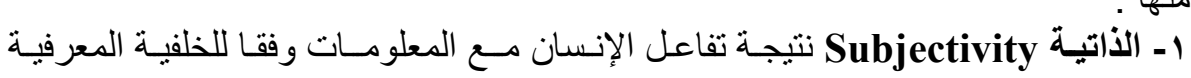

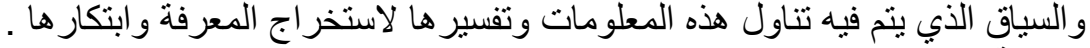

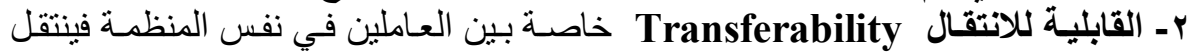

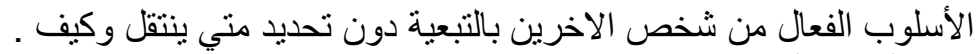

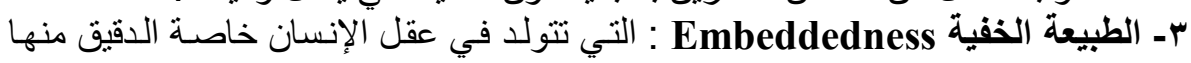

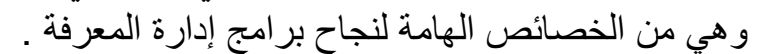

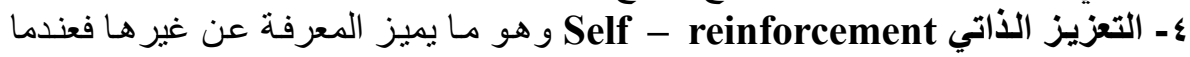

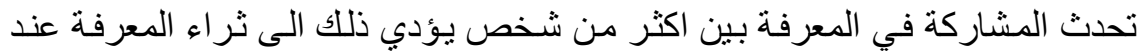

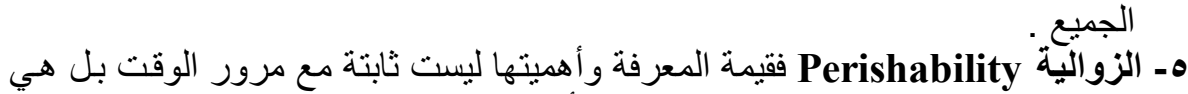

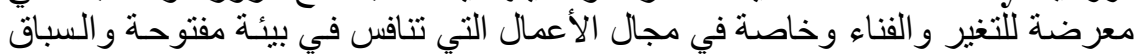

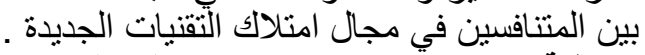

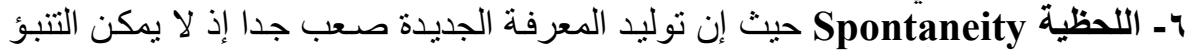

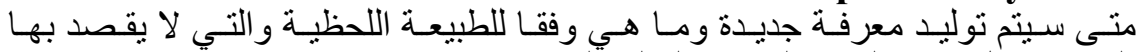

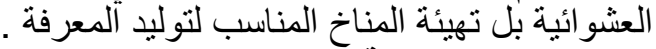

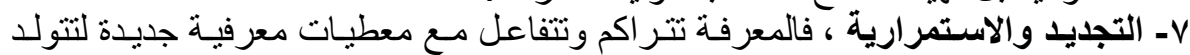

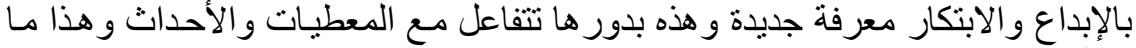
يعطية خاصية الاستمر ارية الإنية

^- ضمنية Tacit : حيث لا تعلن جميع المعارف التي تحتفظ بها عقولهم، بل يحتفظون

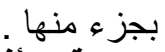
9- موجهة بالأفعال Action-Oriented من خلال الطريقة التي تتولد بها معرفة جديدة

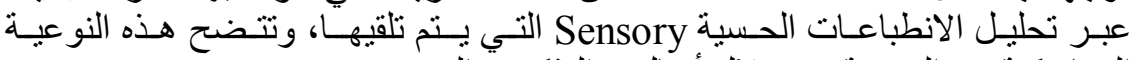
الديناميكية من المعرفة من خلال أفعال، و التذكر ، و الفهح.

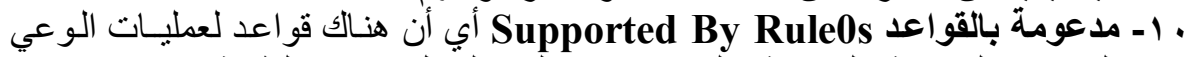

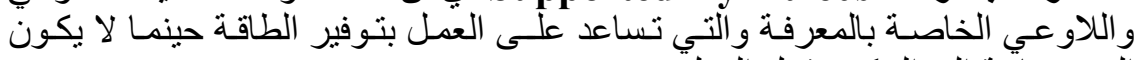
الفرد بحاجّة إلى التفكير قبـل العمل. 
1 ا - متفيرة باستمرار Constantly Changing أب أنها متغيـرة بشكل مستمر وهي

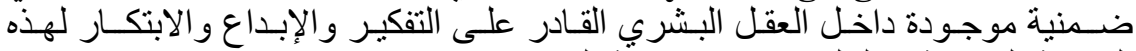

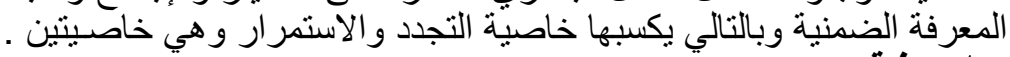

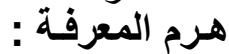

مثل باقي العلوم أيضا المعرفة تبدأ بمرحلة وتنتهي بمرحلة اكثر دقة ولة واكثر تحديا

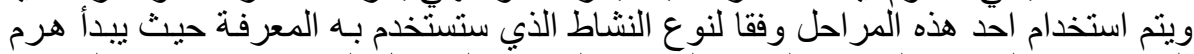

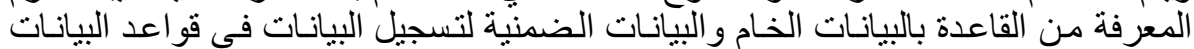

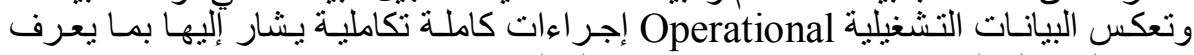

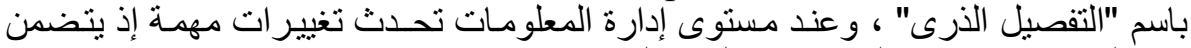

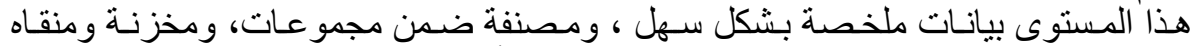

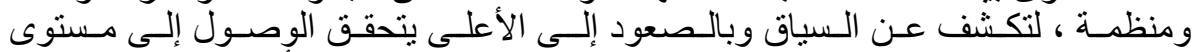

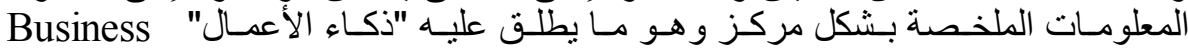

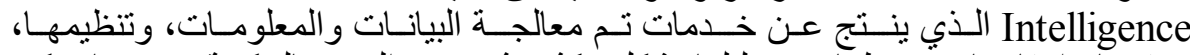
وتتقبتها و انتقاؤها ، وربطها ، وتحليلها بشكل مكثف ثم ينتهي الهرم بالحكمة و هو مـا يمكن

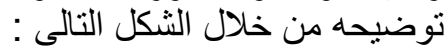

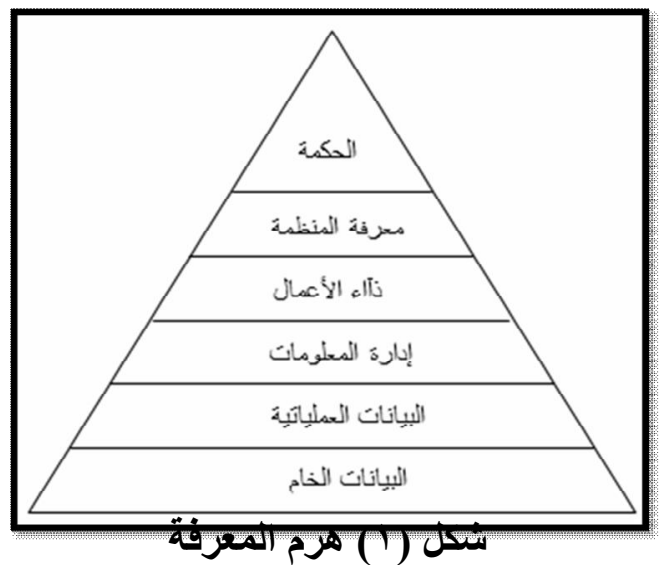

لكل منظمة آلية خاصة بها لتحقيق أهدافها وبناء عليه اختيار نوع المعرفة المناسب

$$
\text { أنواع المعرفـة : الكمل }
$$

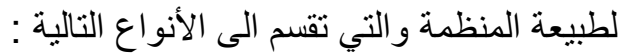
() المعرفة الإدر اكية : تتعلق بالمبادئ والقو انين والأسس و القو القو العد الأساسية للعلوم النظريـة و التطبيقية .

r) المعرفـة الفنيـة (التقنيـة) : تتعلق بالمهارة الفنيـة والقدرة على إنجـاز الأعمـال وامتلاك

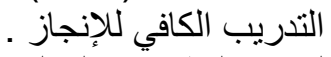

r) الحكمة التطبيقية والعملية والتي التئية تظهر في الممارسات الاجتماعية بصورة أساسية .

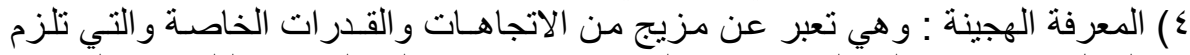

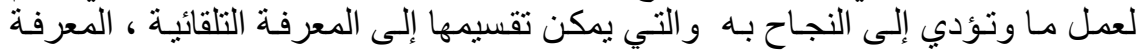

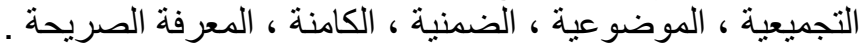

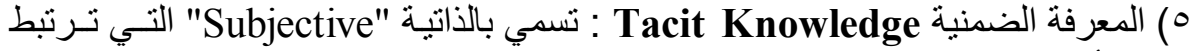

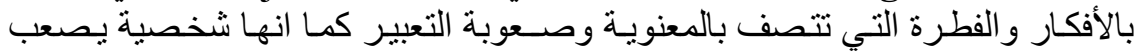
تشكيلها كما انها معقدة.

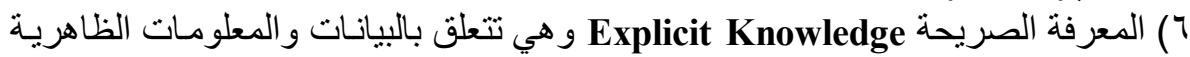

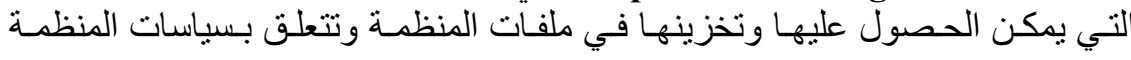




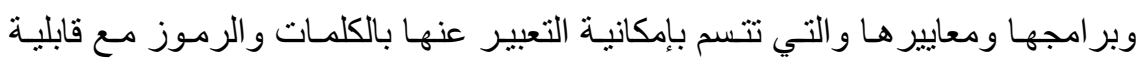

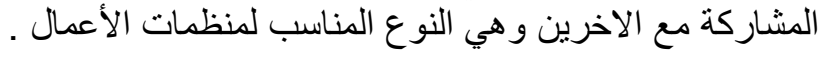

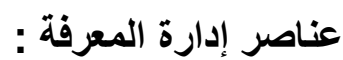

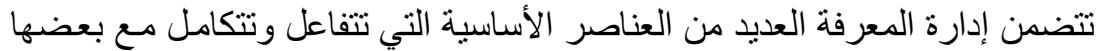

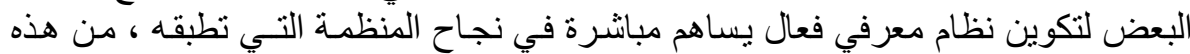

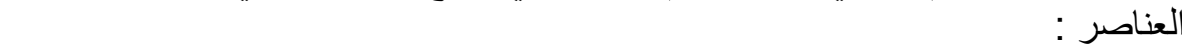
1 ـ أساسية : Essential : إحدى أساسيات الموجودات غير الملموسة في عمليـات المنظمـة،

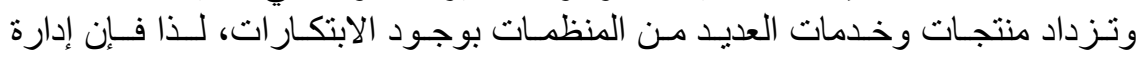

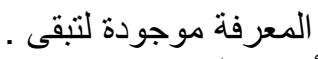

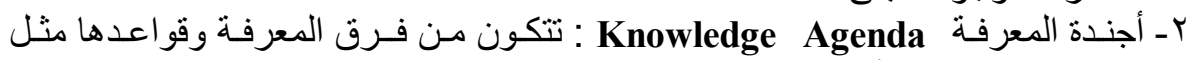

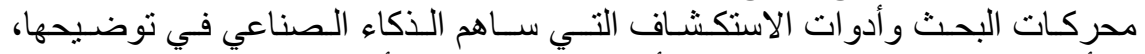

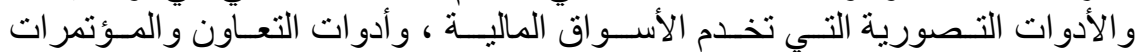

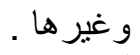

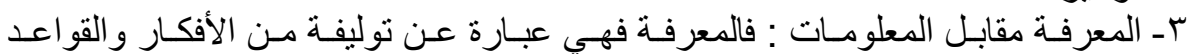

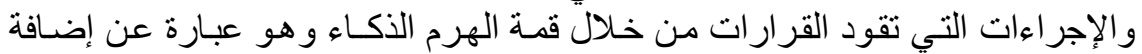

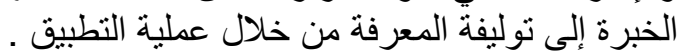

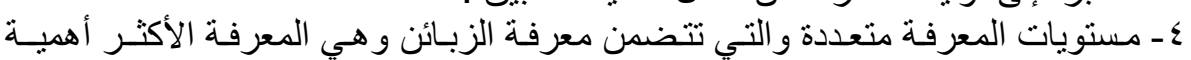

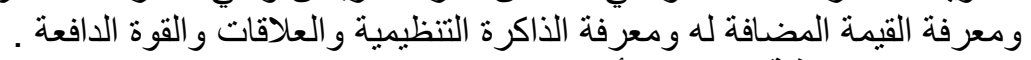

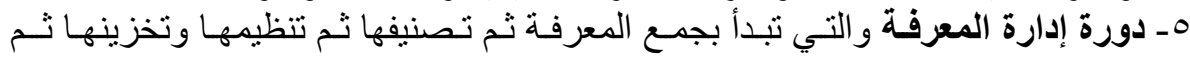

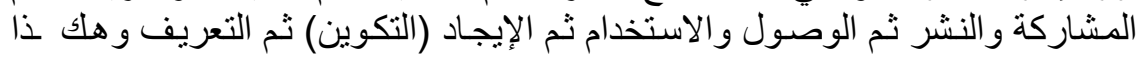

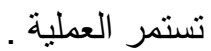

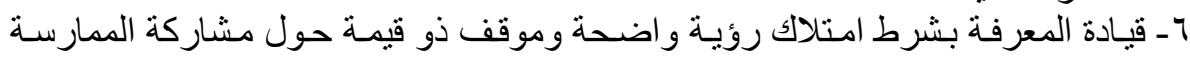

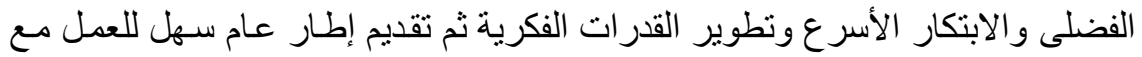

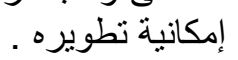

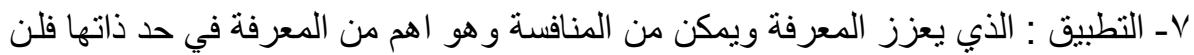

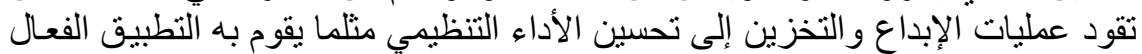

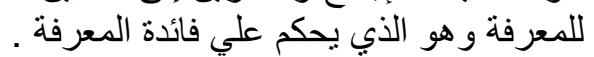

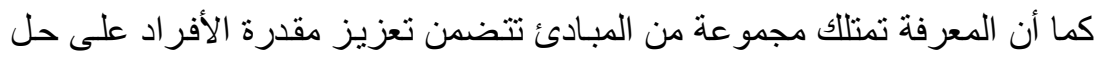

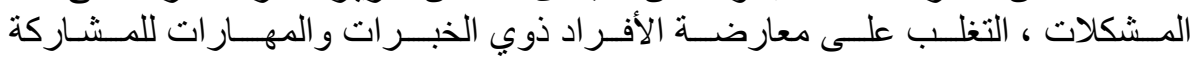

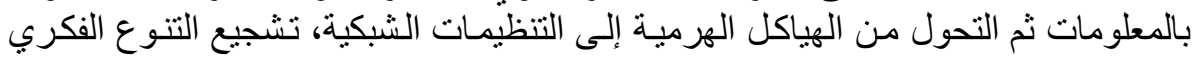

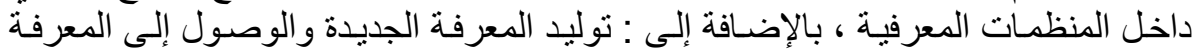

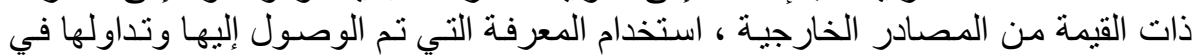

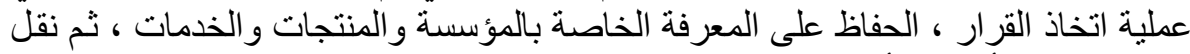

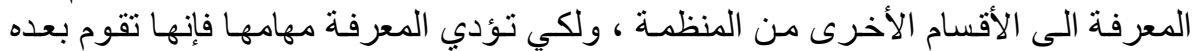

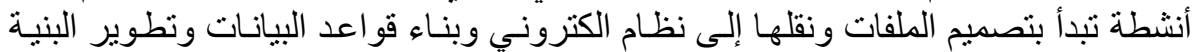
الأساسية لمعالجة المعلومات التي تسهم في تطوير المعرفة ثم تسويق هذه المعرفة للآخرين

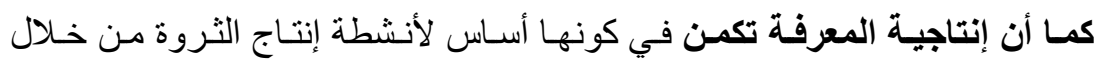

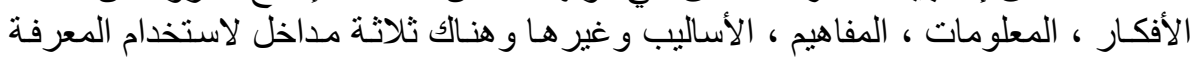

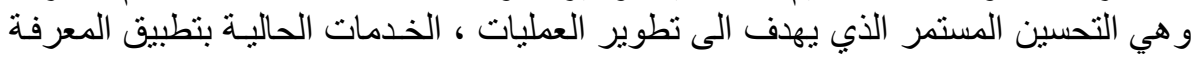

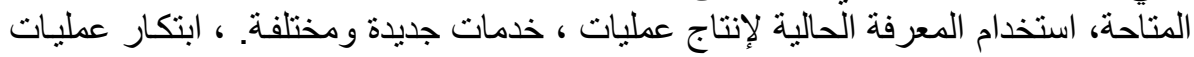




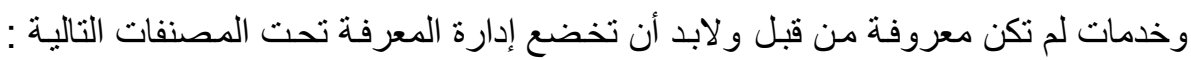

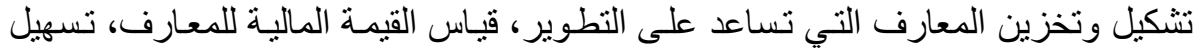

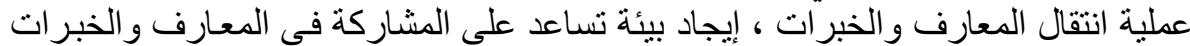

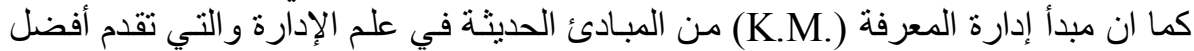

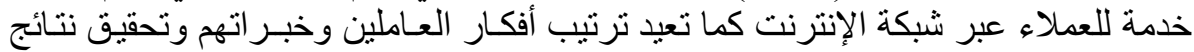

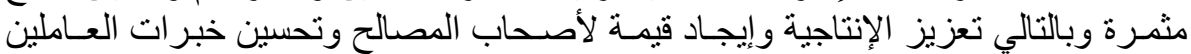

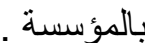

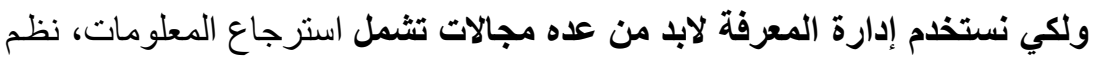

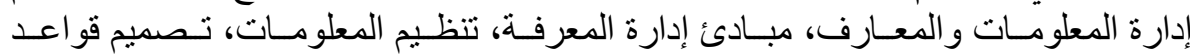

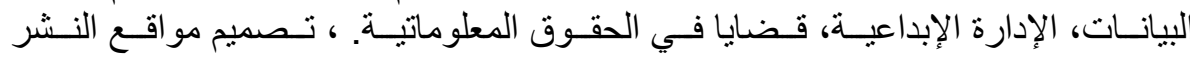

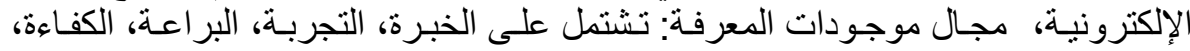

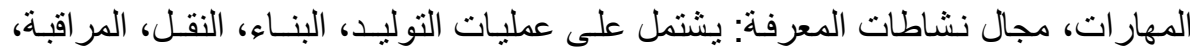

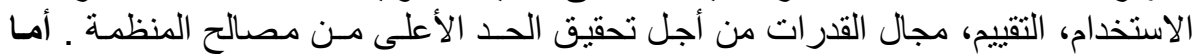

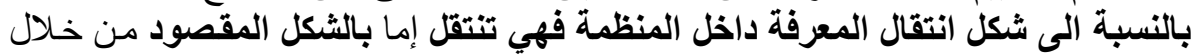

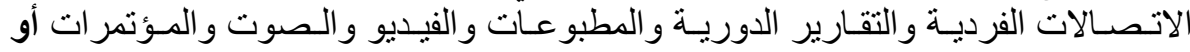

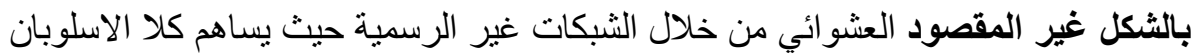

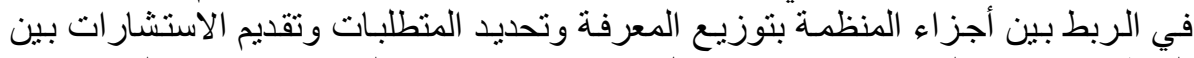

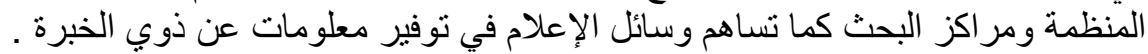

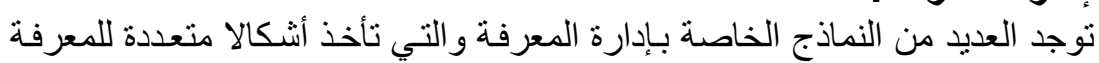

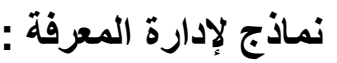

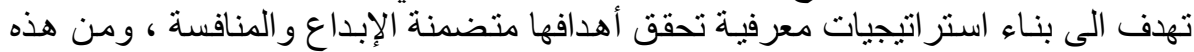
النماذج :

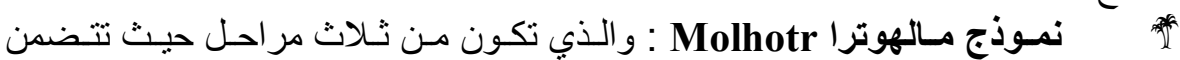

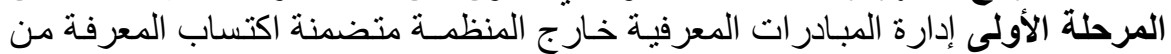

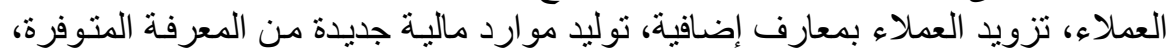

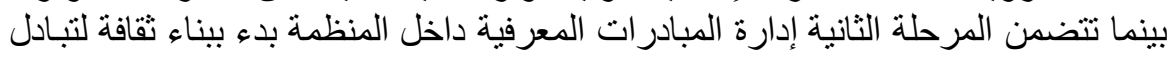

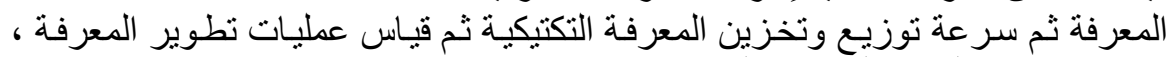

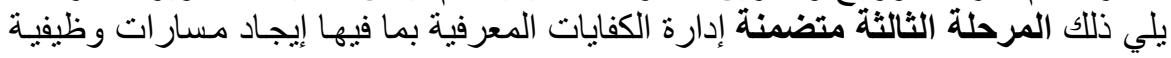

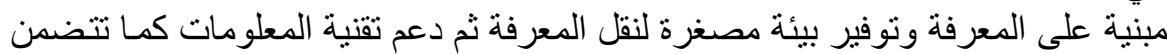

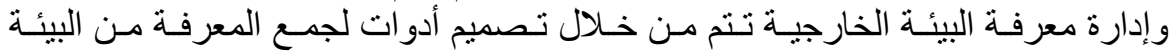

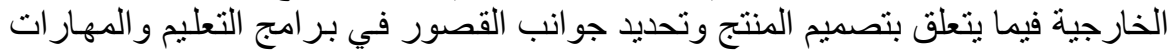

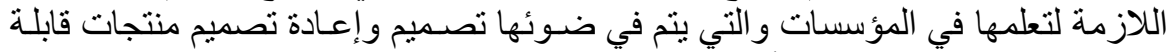

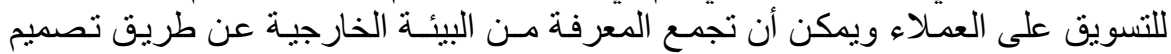

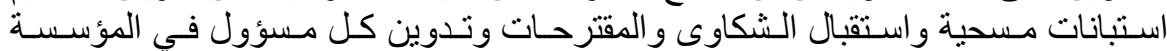
لملاحظاتـه حول موقف العمـلاء الخارجين

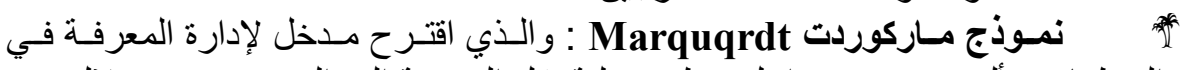

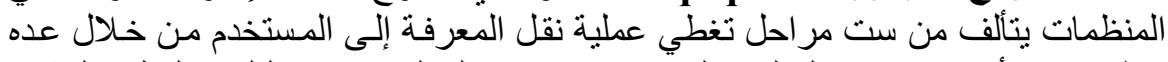

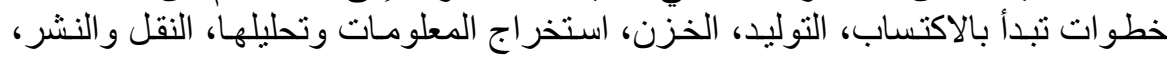

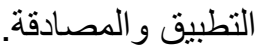

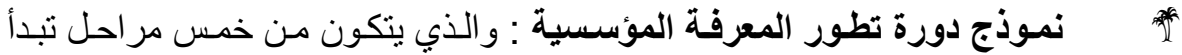

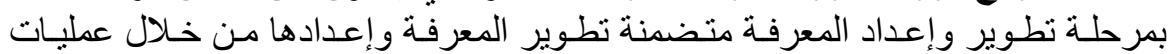




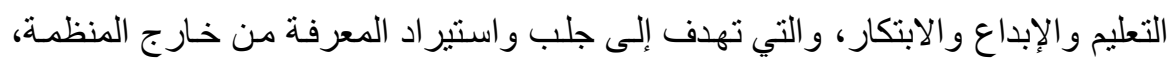

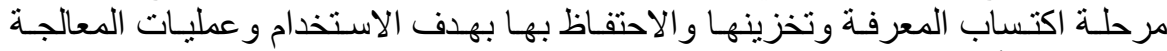

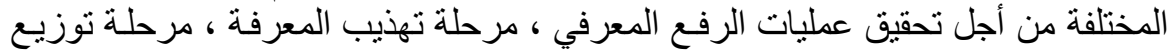

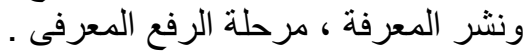

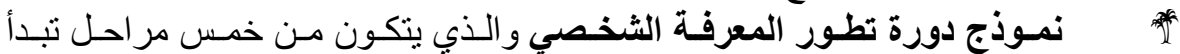

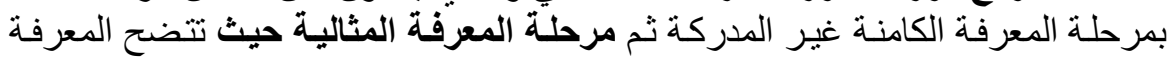

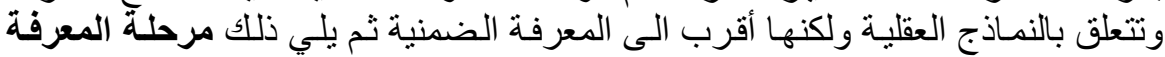

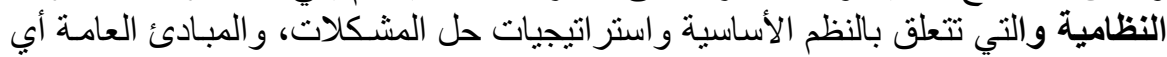

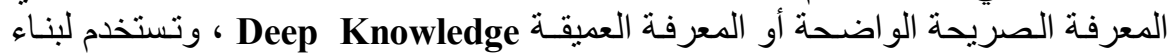

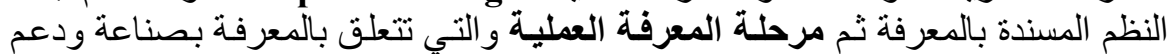

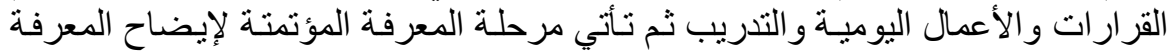

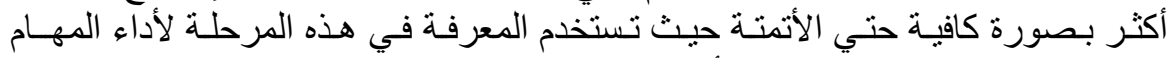

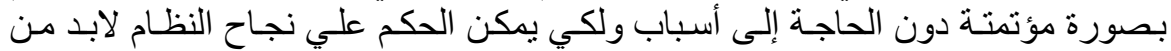

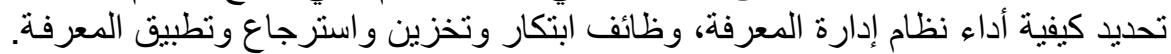

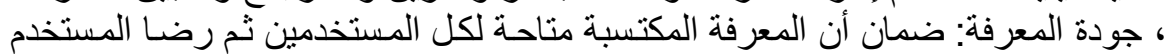

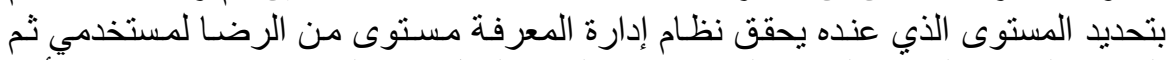

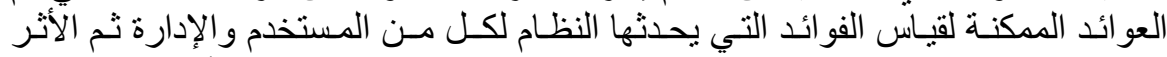

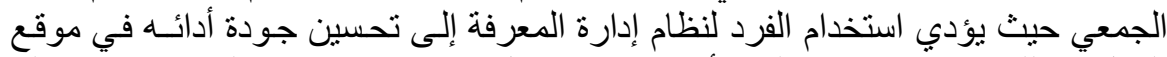

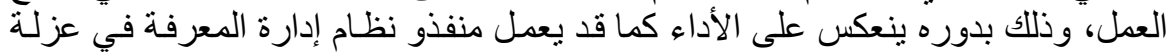

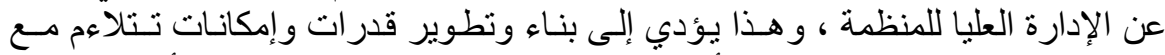
معتقداتهم الثخصية وقناعاتهم بالأنشطة والمئية المارسات التشغيلية و الوظيفية الأفضل .

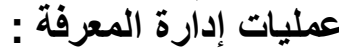

و هنا تمر المعرفة بثلاثة عمليات وهي توليد المعرفة، نقل المعرفة والتشارك فيها

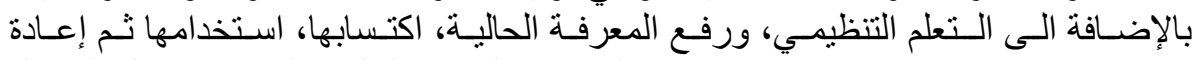

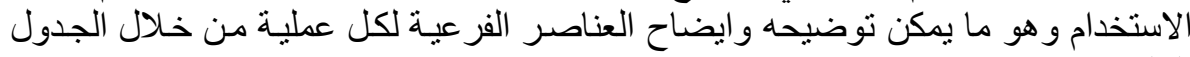

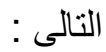

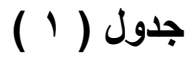 \\ عمليات إدارة المعرفة}

\begin{tabular}{|c|c|}
\hline \multicolumn{2}{|l|}{ عمليات إدارة المعرفة والأنشطة الفرعية التابعة } \\
\hline وإكتشاف المعرفة ، الإمساك بها ، التزويد ، تطوير هـا وتتميتها ، تحديثها & المعرينة \\
\hline تفيانتها والمعرفــة ، تصنيفافها وتوحيـدها ، تجميعهـا وتبوبيهـا ، تقييمهـا ، & تلنظيمة \\
\hline وجزئ سارية المفعول . ومايتها وتحقيق سبل الوصول إليها و إقرارهـا رسميا ، & 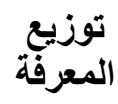 \\
\hline 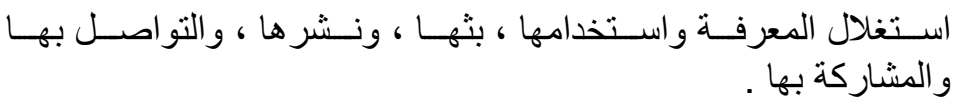 & تلطبيقي \\
\hline
\end{tabular}

المصدر : نموذج إدارة المعرفة عذد Duffy ، 1. أ. م. 


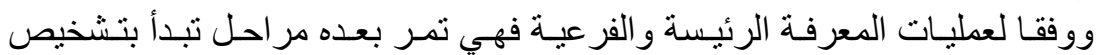

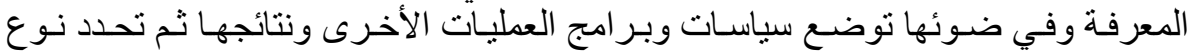

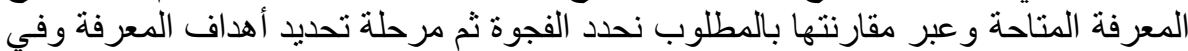

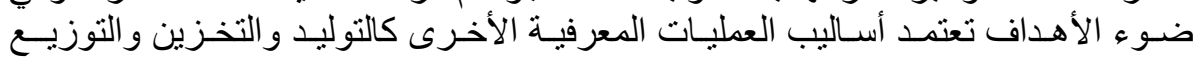
و التطبيق وهو ما يمكن تناوله من خلال النالي النقاط التالية : ـ قيام المنظمة بتطوير هياكل و عمليـات متكاملـة لاكتسـاب المعرفة من داخل أو خـارج المنظمة المنام

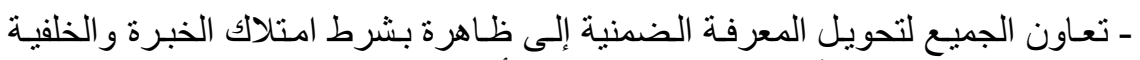

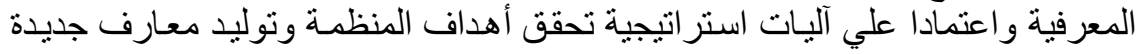

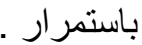

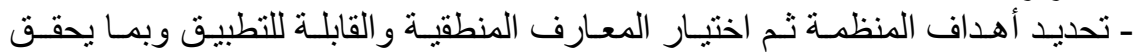

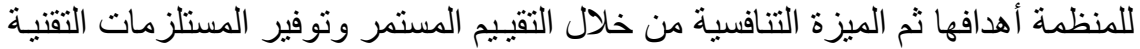

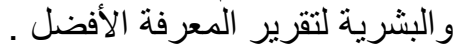

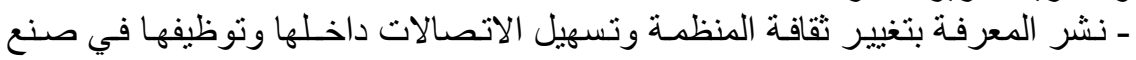

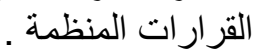

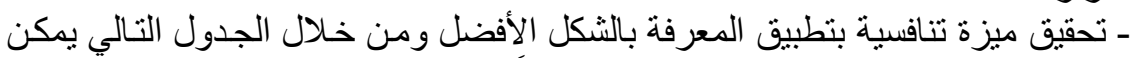

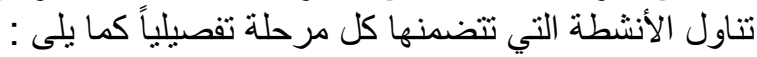

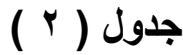 \\ مراحل إدارة المعرفة ( مانة}

\begin{tabular}{|c|c|}
\hline \multicolumn{2}{|l|}{ مراحل إدارة المعرفة والأنشطة التي تتضمنها كل مرحلة } \\
\hline 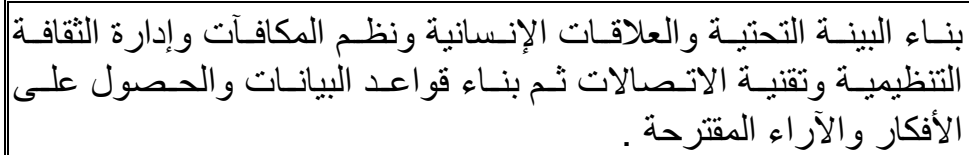 & المبادرة \\
\hline 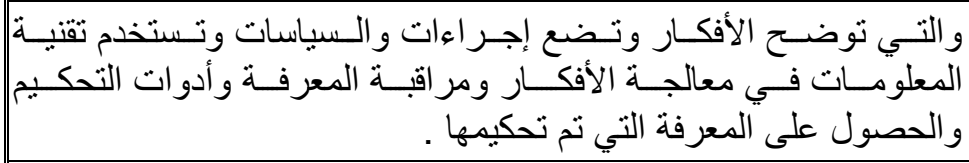 & النشر \\
\hline 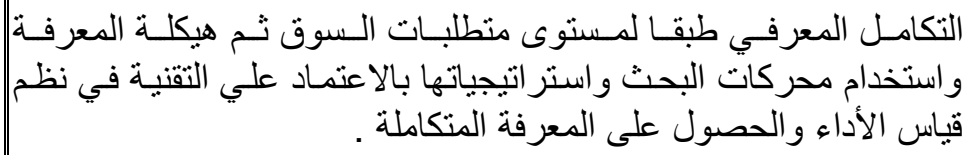 & الداخلي \\
\hline 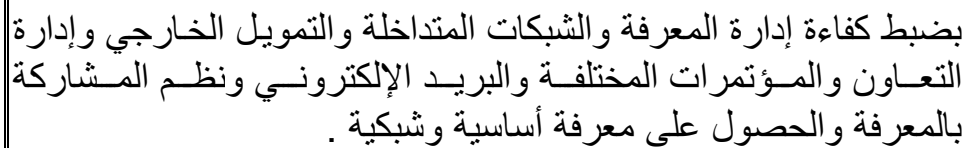 & الخارجي \\
\hline
\end{tabular}

المصدر : نموذج إدارة المعرفة عند Marquardt, 2002

كما تمر إدارة المعرفة بعمليات أساسية تتضمن أنشطة فر عيـة يمكن توضيحها من

جدول (r)

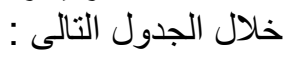

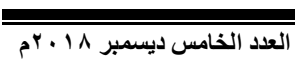




\begin{tabular}{|c|c|}
\hline 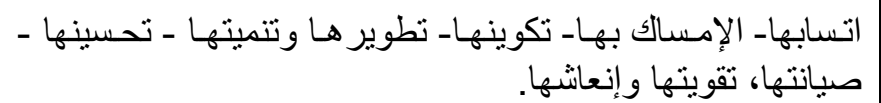 & 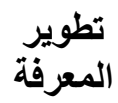 \\
\hline 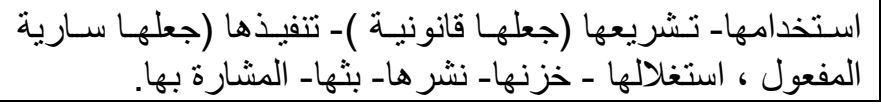 & ت المعرفيقة \\
\hline 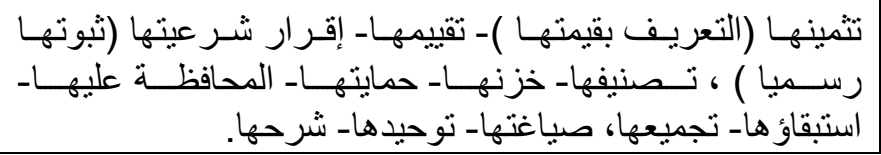 & المعرفيمة \\
\hline
\end{tabular}

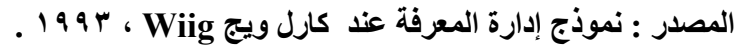

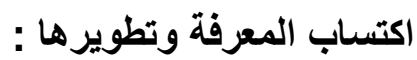

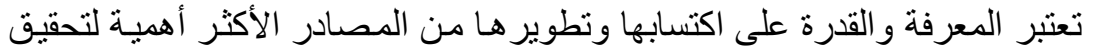

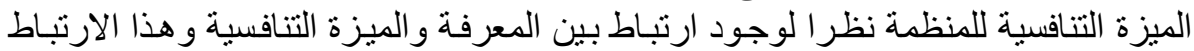

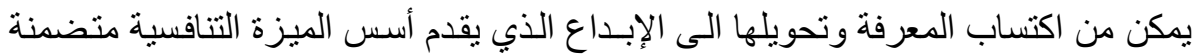

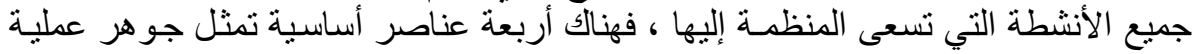

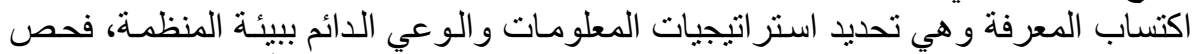

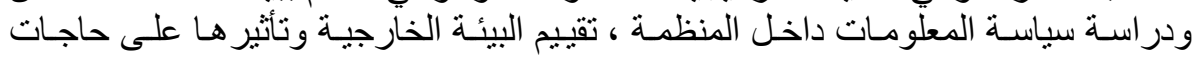

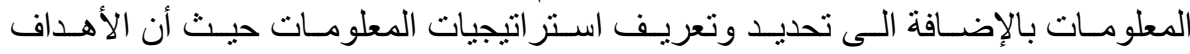

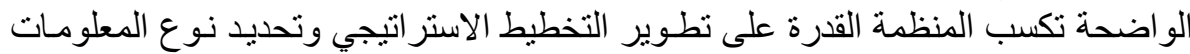

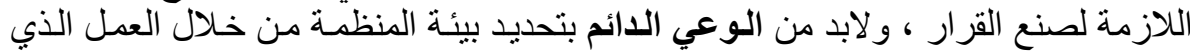

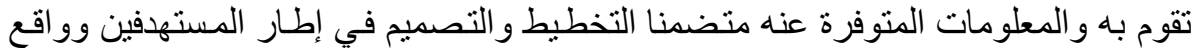

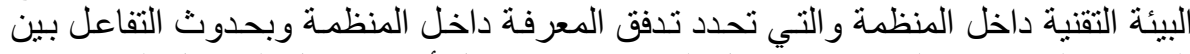

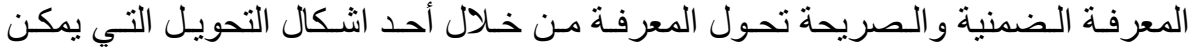

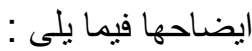

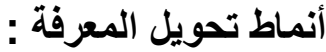

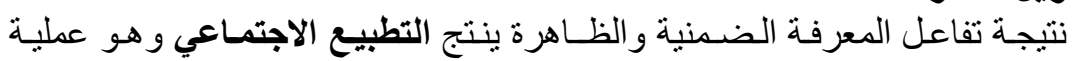

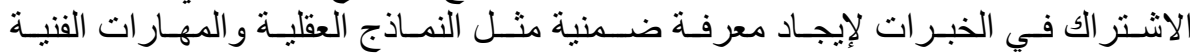

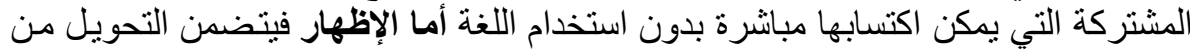

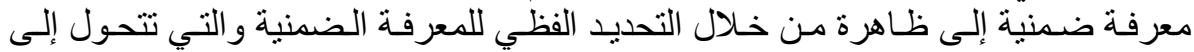

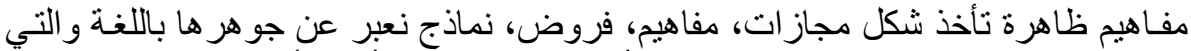

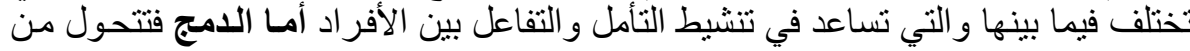

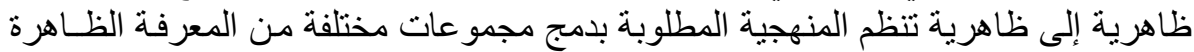

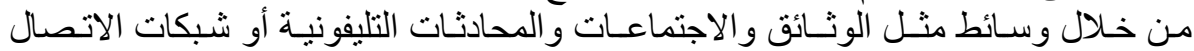

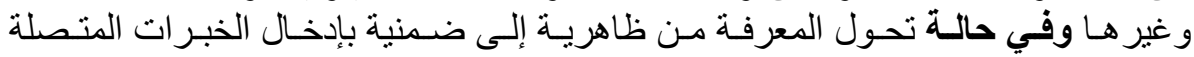

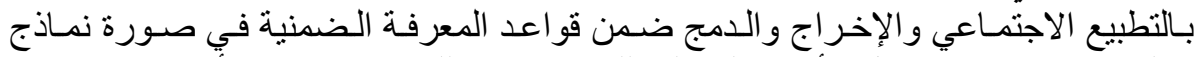

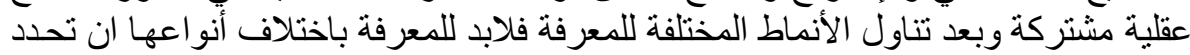

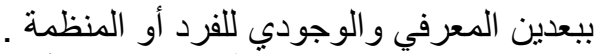

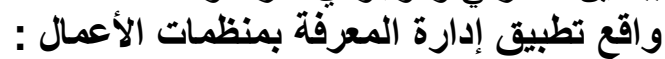

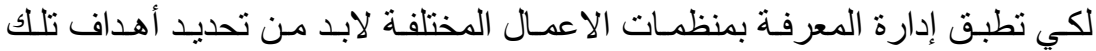

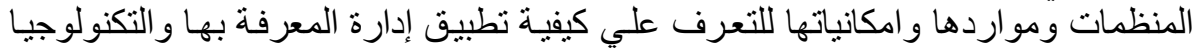

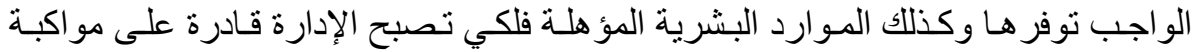

مجلة اللراسات التجارية المعاصرة




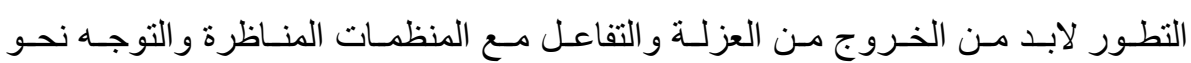

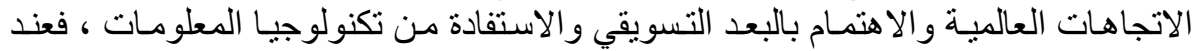

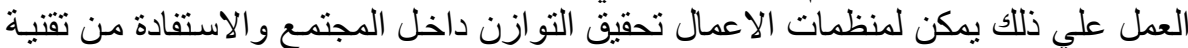

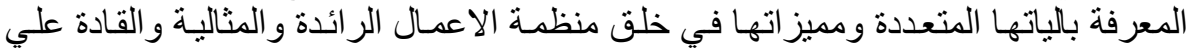

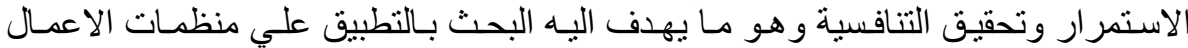

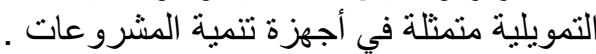

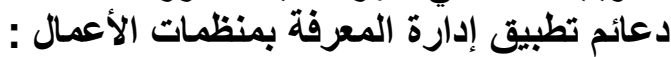

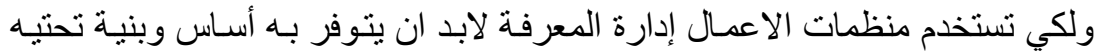

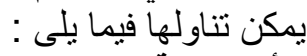

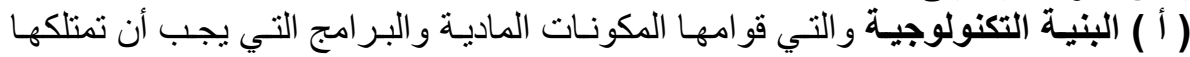

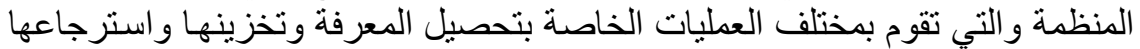

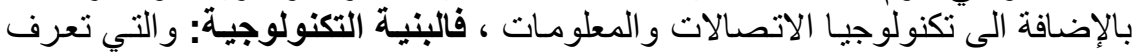

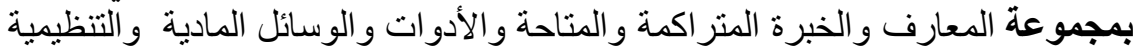

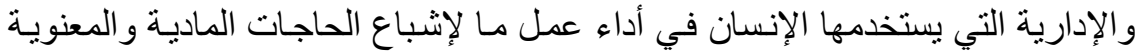

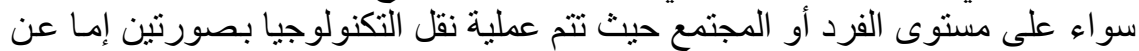

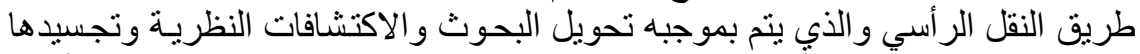

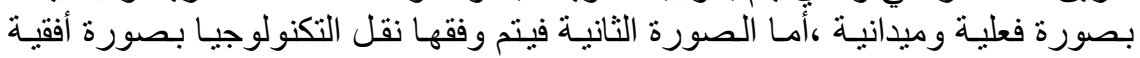

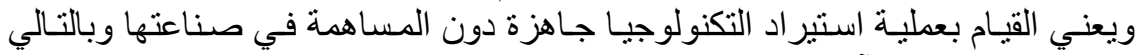

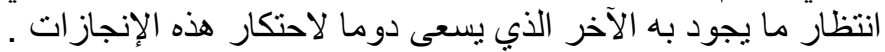

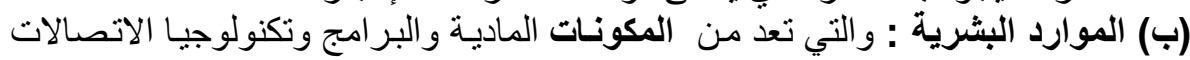

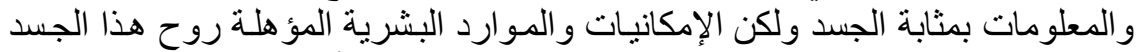

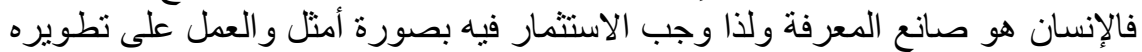

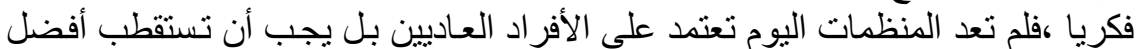

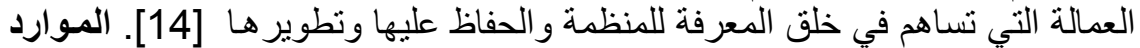

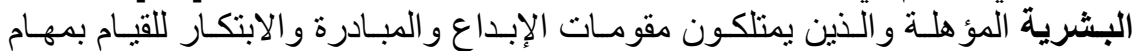

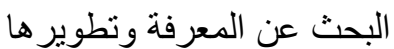

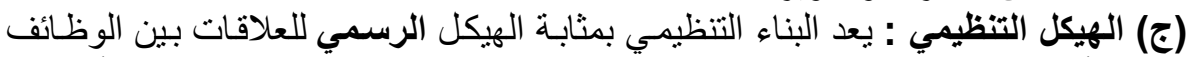

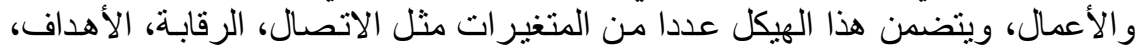

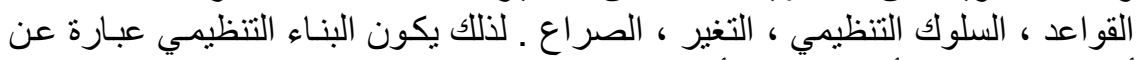

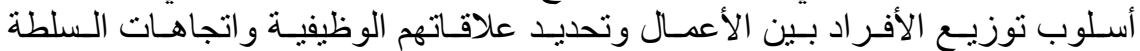

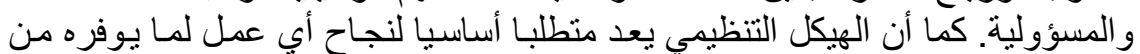

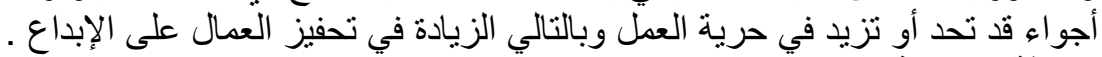

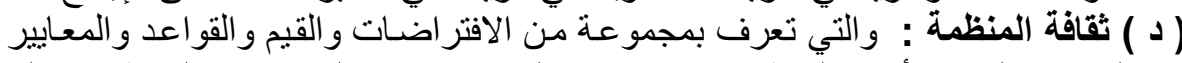

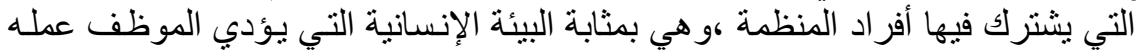

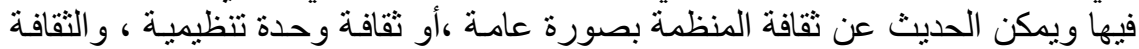

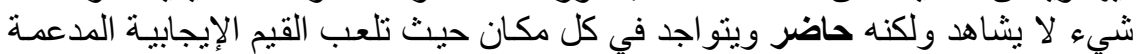

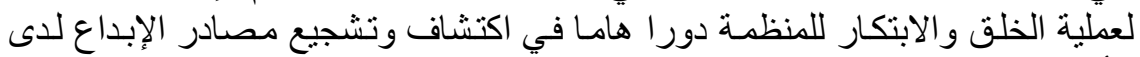

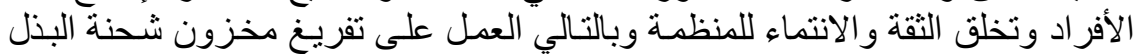

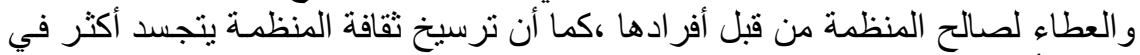

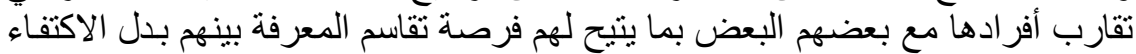
بتخزينها فقط. المشروعات الصغيرة وجهاز تنمية المشروعات : 


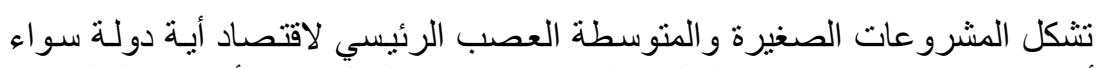

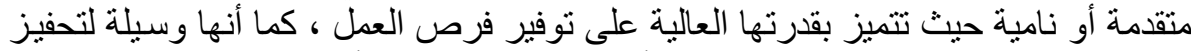

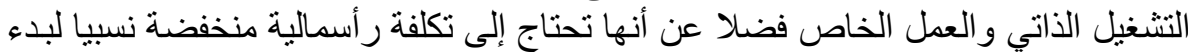

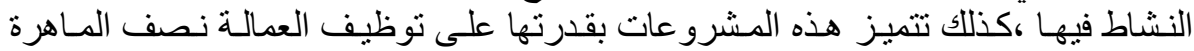

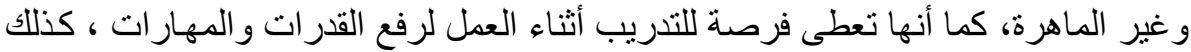

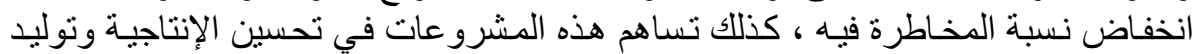

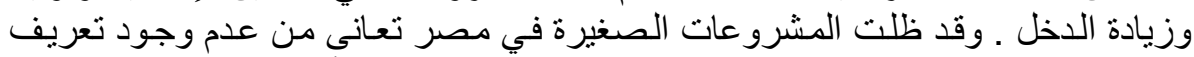

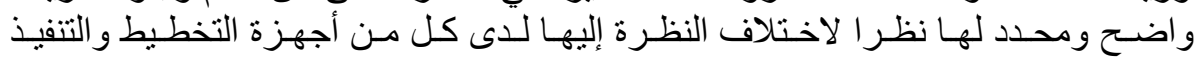

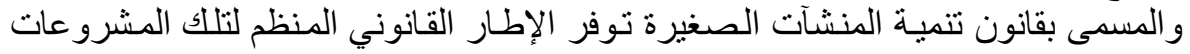

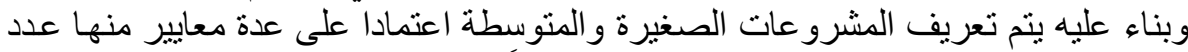
العمال ، حجم رأس المال أو خليط بين المعيارين معاً .

لذلك يعد جهاز تنمية المشروعات شبكة أمان اجتماعي و اقتصادي تسهم في محاربة

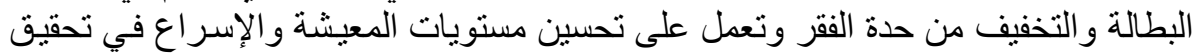

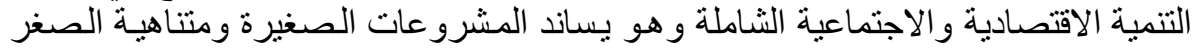

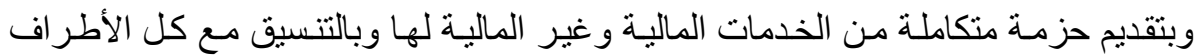

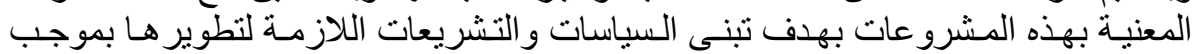

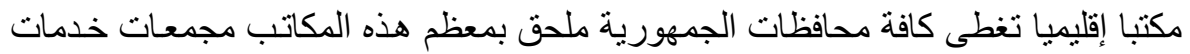

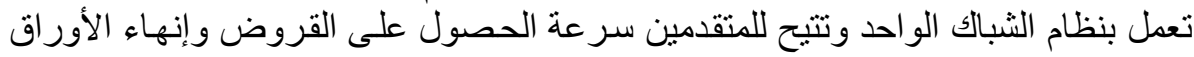
المطلوبة و الحصول على خدمات استخر اج التراخيص والسجل التجاري و البطاقة الضريبية التران

يهدف الصندوق الاجتماعي للتنمية الي التعامل مع الآثار الجانبية لبرنـامج الاصدلاح

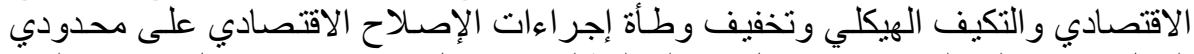

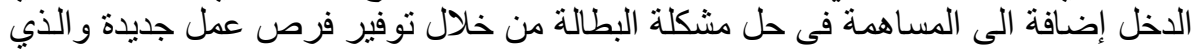

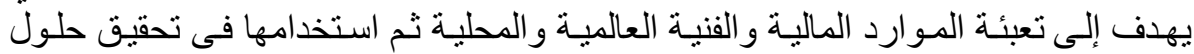

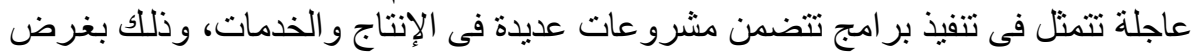

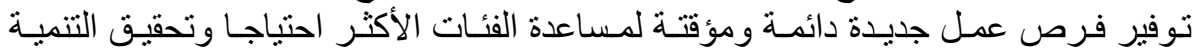

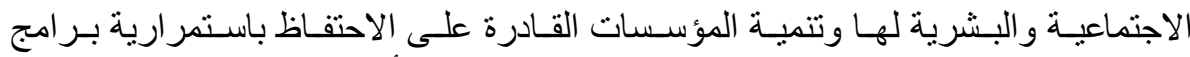

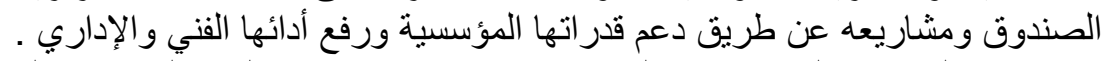

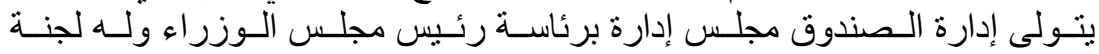

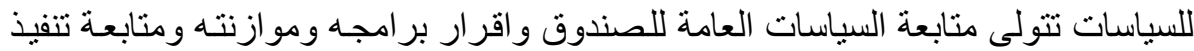

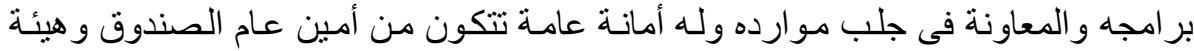

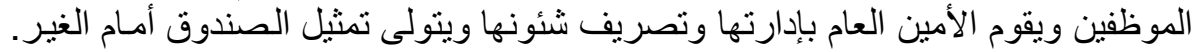

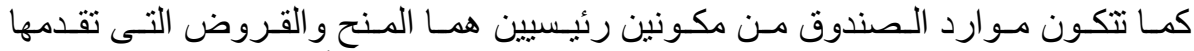

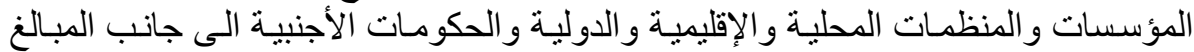

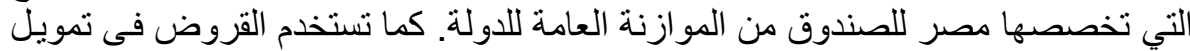

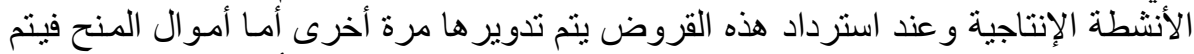

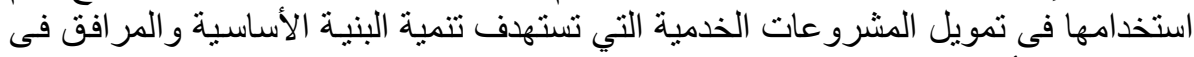

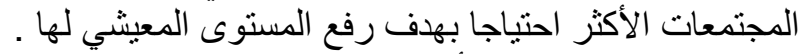

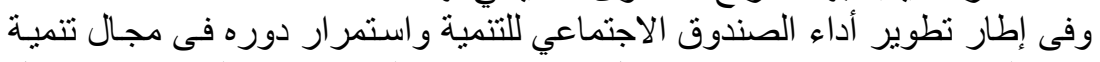

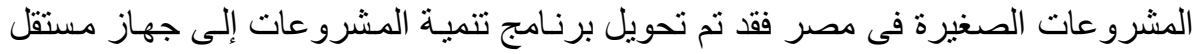




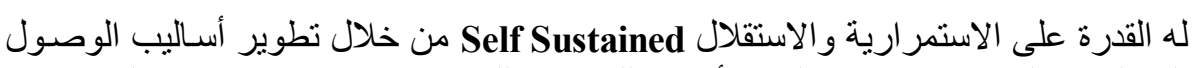

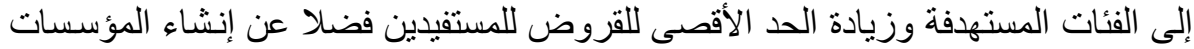

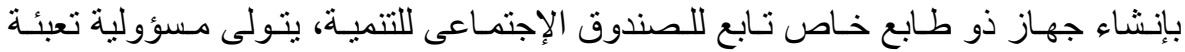

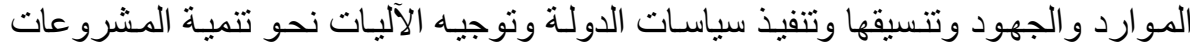

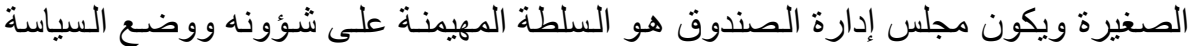

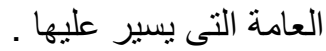

\section{التطور التاريخى لجهاز تنمية المشروعات :}

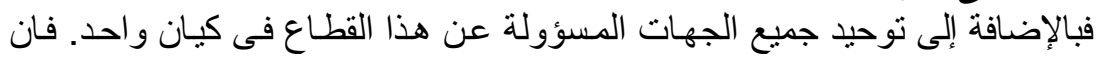

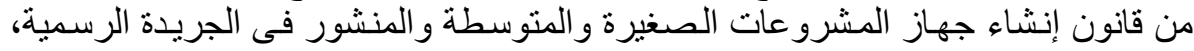

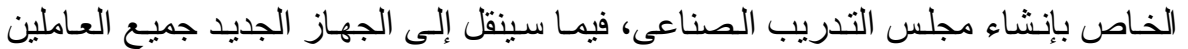

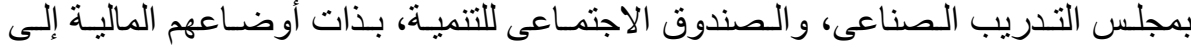
جانب جميع الأصول و الأموال ومقار المجلسين

\section{مجالات عمل جهاز تنمية المشروعات :}

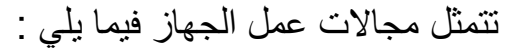

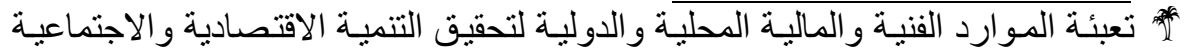

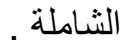

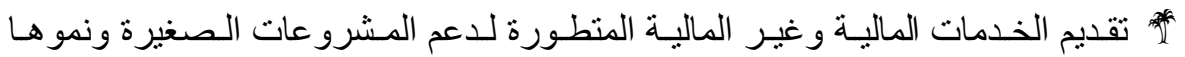
وتطور ها.

" تمويل المشروعات التي تتيح فرص العمل وتحسن البنية الأساسية و المجتمعية .

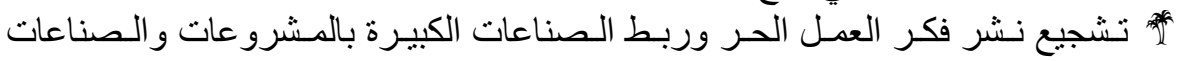

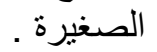

أهداف جهاز تنمية المشروعات :

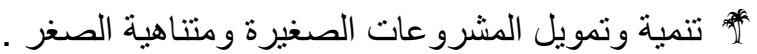

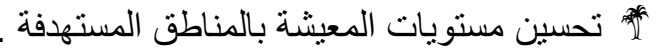
مار المساهمة في إيجاد فرص عمل للحد من مشكلة البطالة خاصة بين الثباب و المر أة .

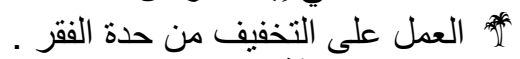
الفئات المستهدفة للحصول علي جهاز تنمية المشروعات :

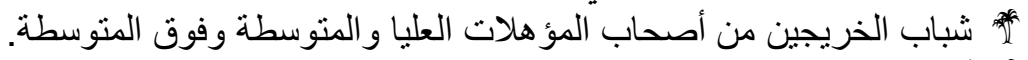

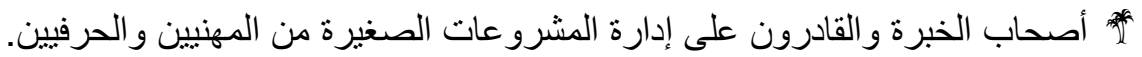

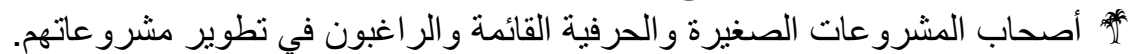

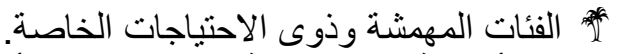
برامج وأنشطة جهاز تثمية المشروعات المات الأساسية :

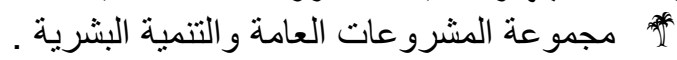

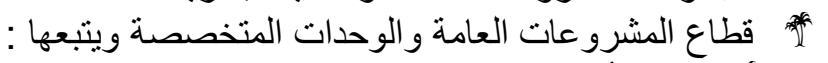

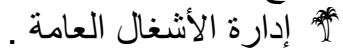

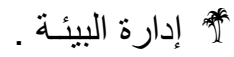




$$
\begin{aligned}
& \text { (إدارة السكان . }
\end{aligned}
$$

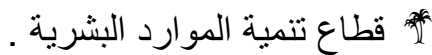

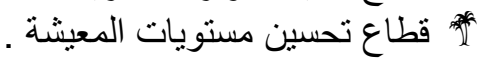

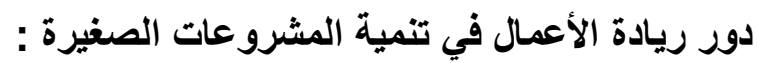

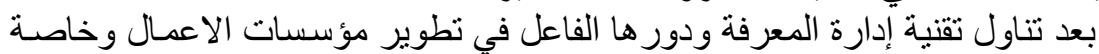

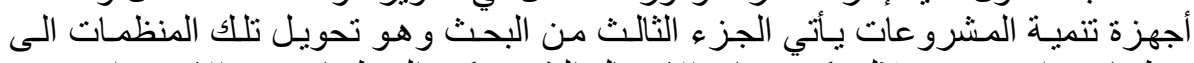

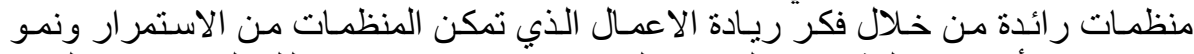

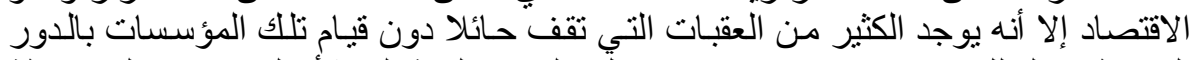

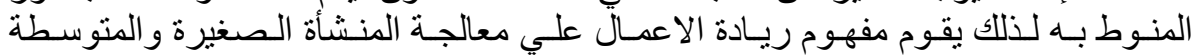

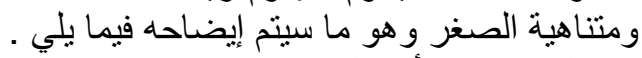
تعريف ريادة الأعمال : مئن

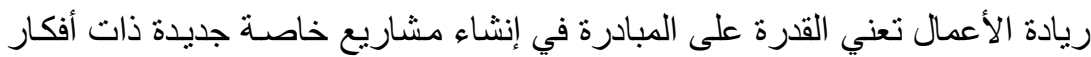

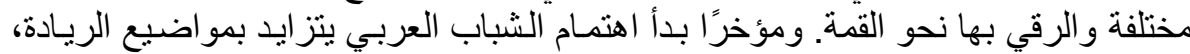

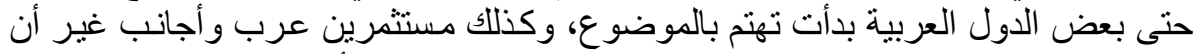

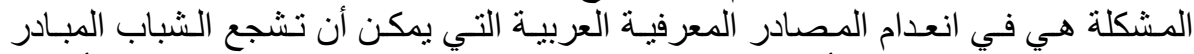

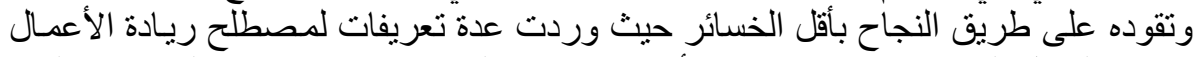

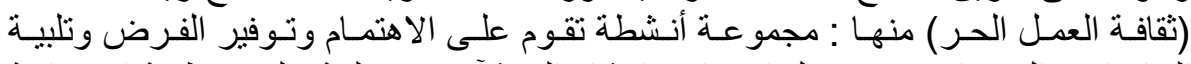

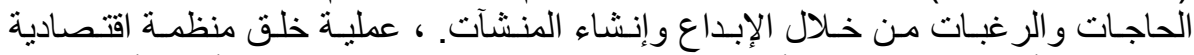

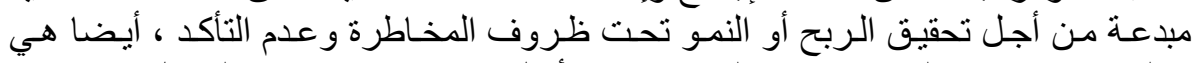

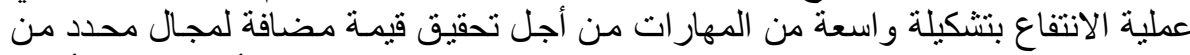

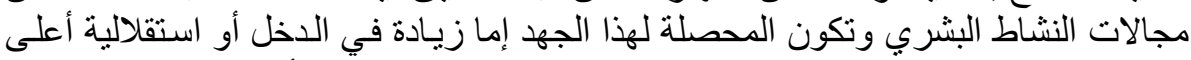

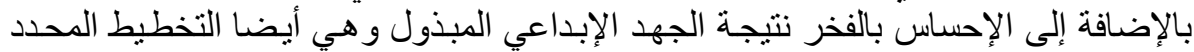

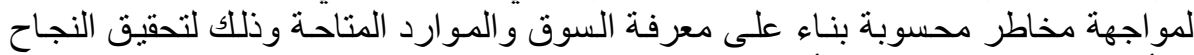

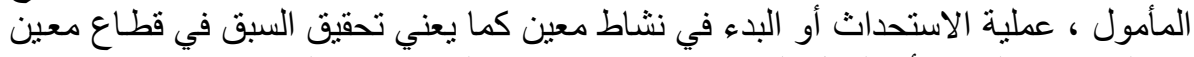

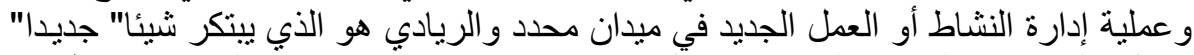

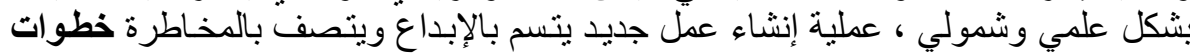

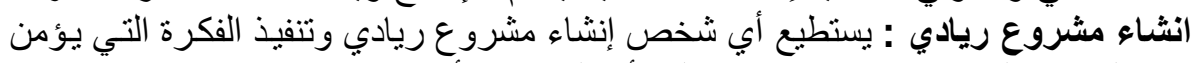

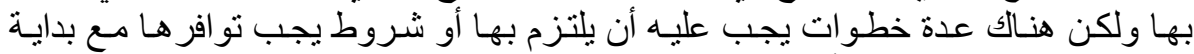

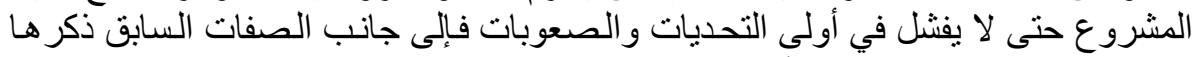

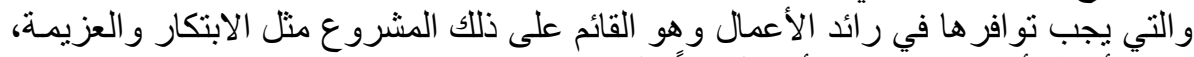

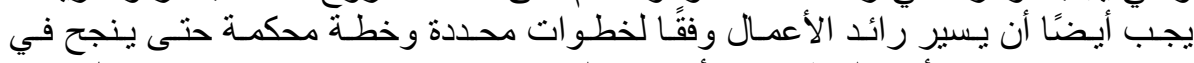

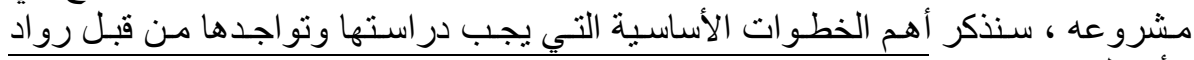

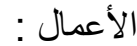

اــــــة : الفكرة هـي العمود الأساسـي للمشروع الريـادي والتي يجب أن تكون مبتكرة

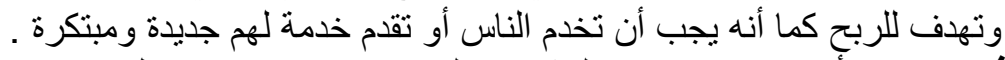

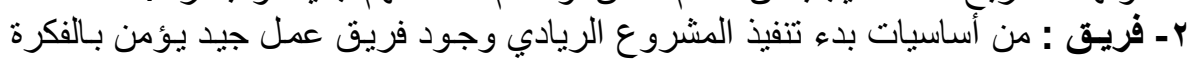

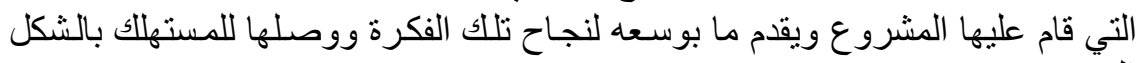

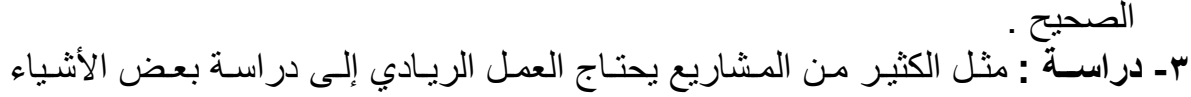

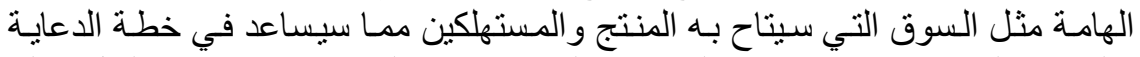

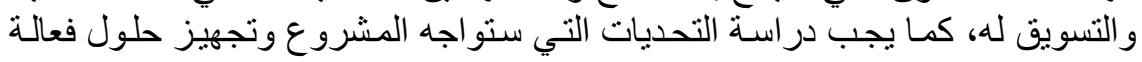

مجلة اللراسات التجارية المعاصرة"




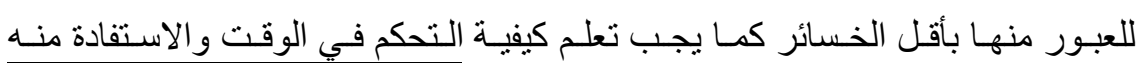

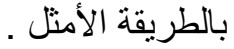

ع - خطة : الخطة التي يسير عليها المشروع هي الخريطة التي يجب أن يلتزم لها القائمين

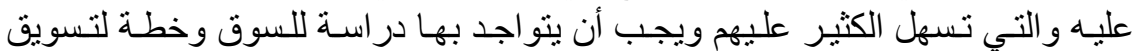

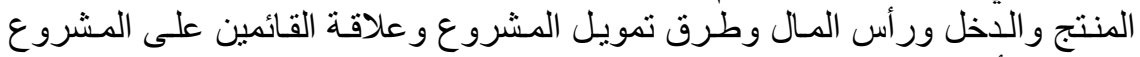

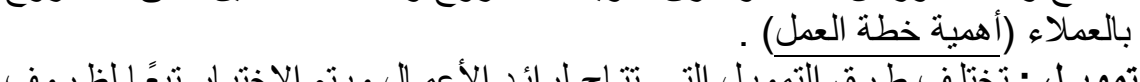

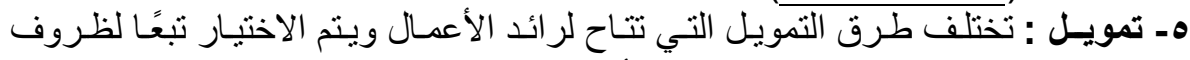

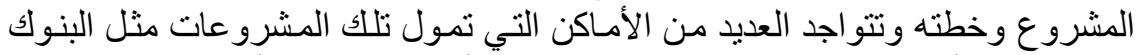

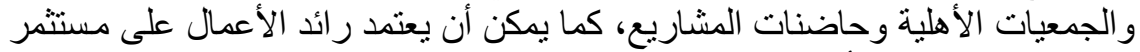

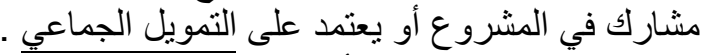

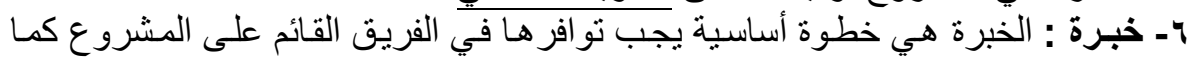

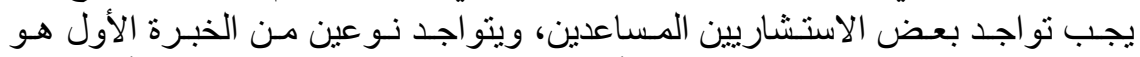

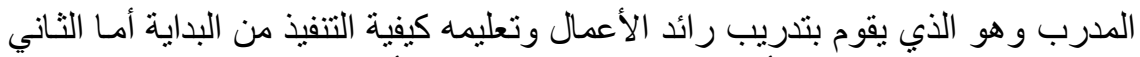

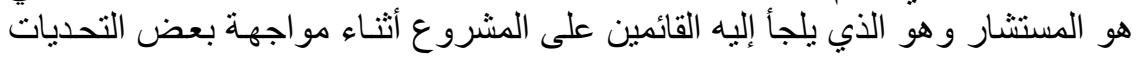

V- تنفيذ : الخطوة الأولى والأخيرة حيث أن التنفيذ هو الخطوة الأخيرة في خطة إنشاء

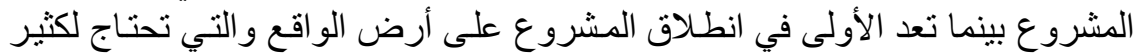

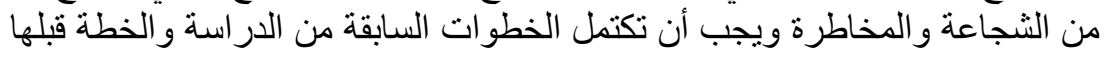

رائد المشروعات الصغيرة Entrepreneur

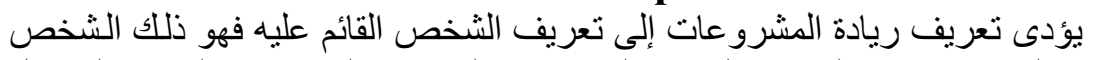

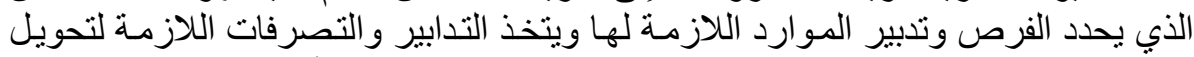

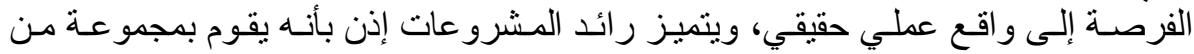

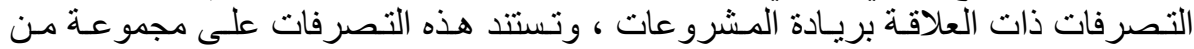

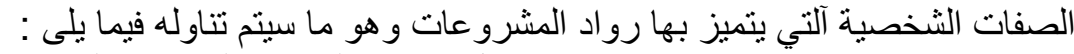

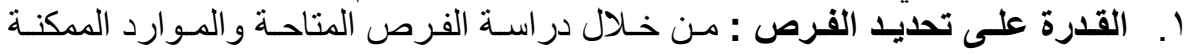

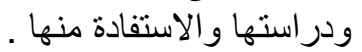
r. القدرة على تدبير الموارد : من خلال امتلاك القدرة العالية في البحث عن المباد الموارد

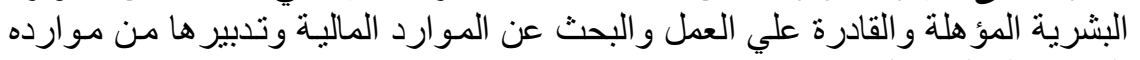

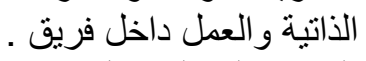

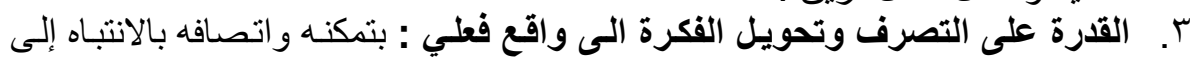

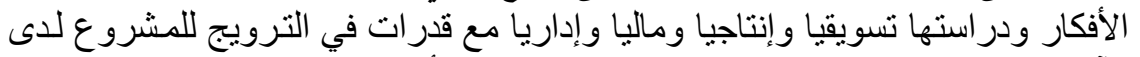

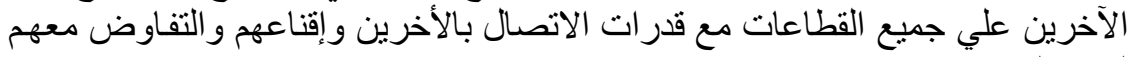

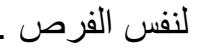

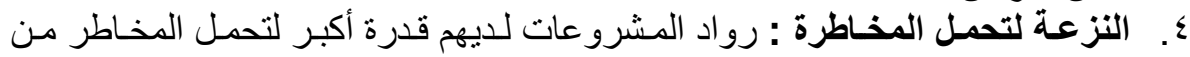

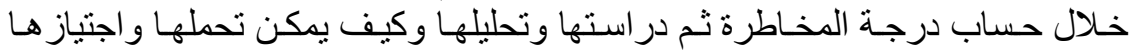

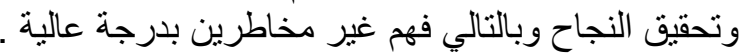

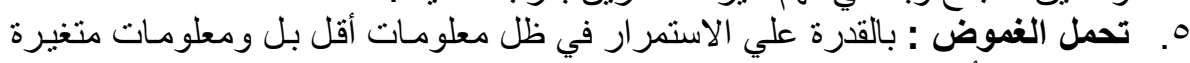

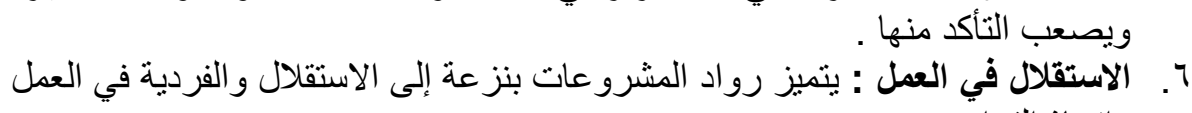
و واتخاذ القرار. 
V. الرغبة في الإنجاز : و التي نتشير الى حب إتمام العمل بنجاح كما يتميزون بقدرة عاليـة

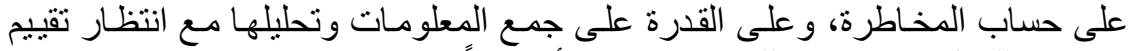
الاخرين للعمل سواء كان ذللك تقدير معنويا أو مأو مادياً .

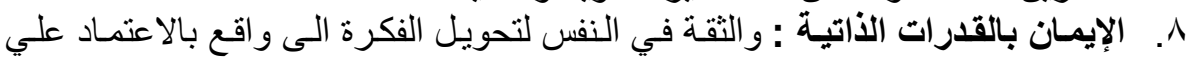

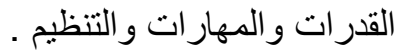

\section{الاراسة التجريبية للبحث :}

حيث تم اختيار عينة البحث من المتقدمين الى جهاز تنمية المشروعات بمحافظة كفر الثيخ

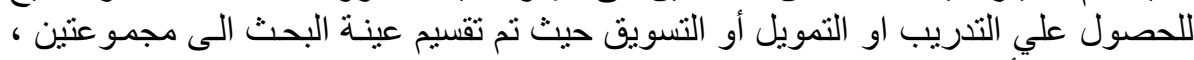

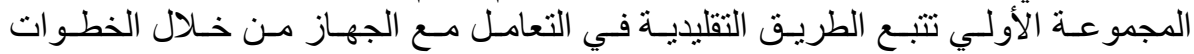

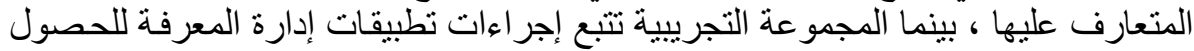

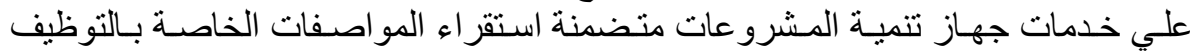

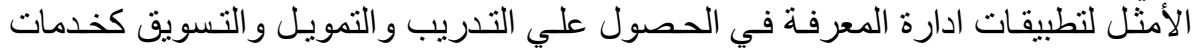

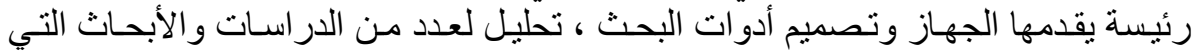

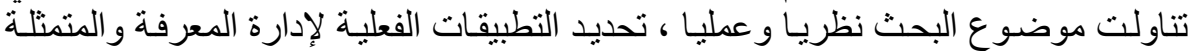

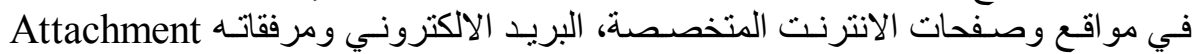

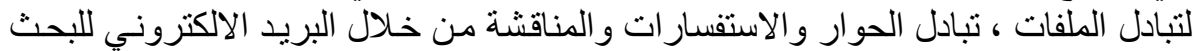

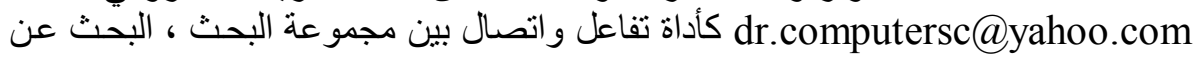

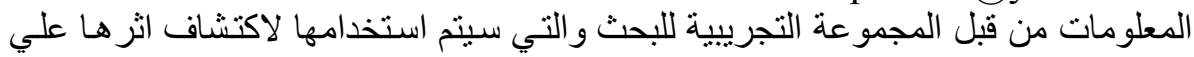

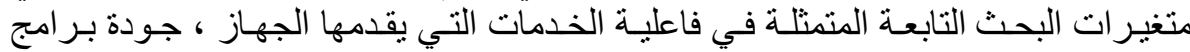
التدريب ، سهولة الحصول علي التمويل وتعدد مصادر عليه وسـهوله إجراءات التهات الحصول علي الخدمات المقدمة . ت النة

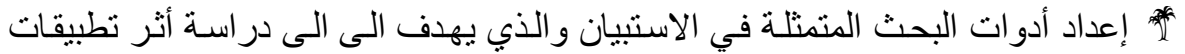

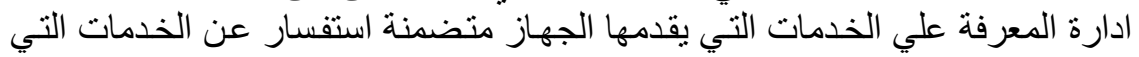

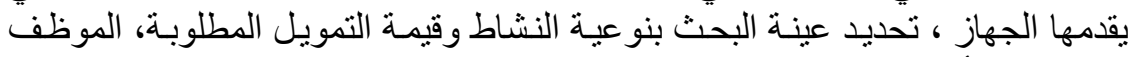

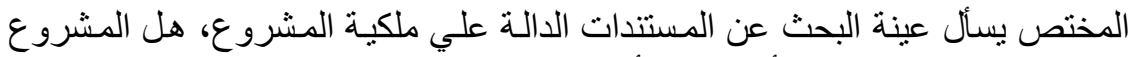

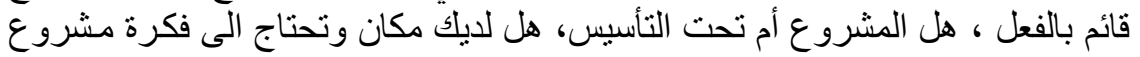

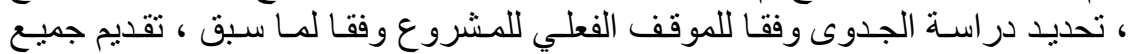

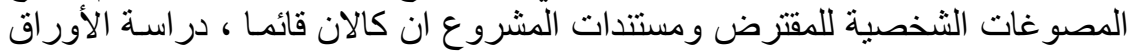

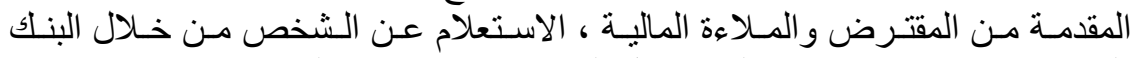

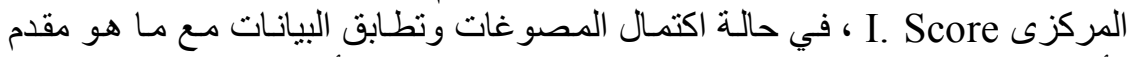

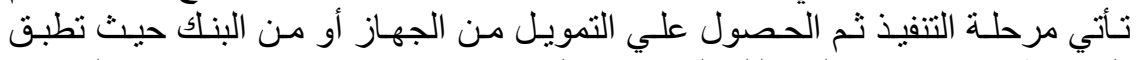

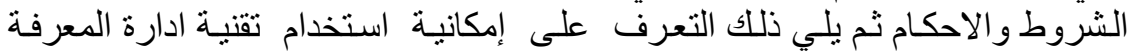

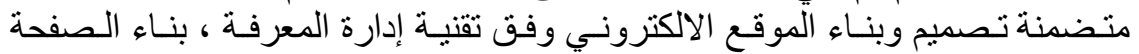

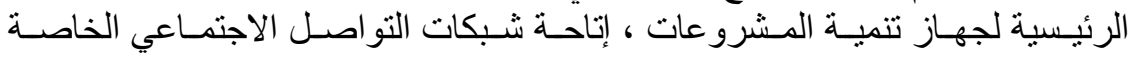

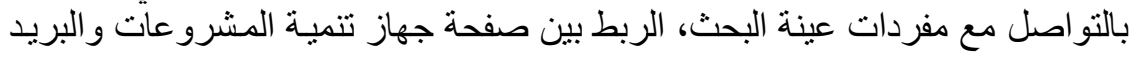

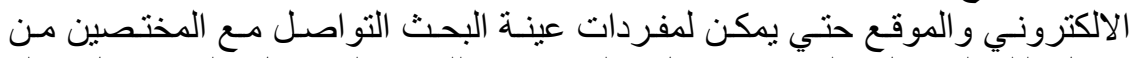

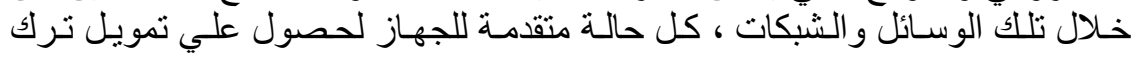

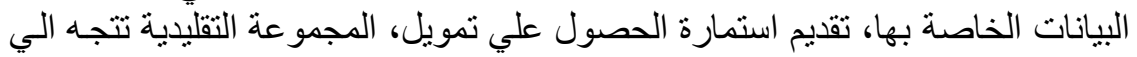

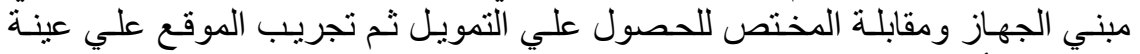
تجريية للتأكد من فاعلية الموقع . 


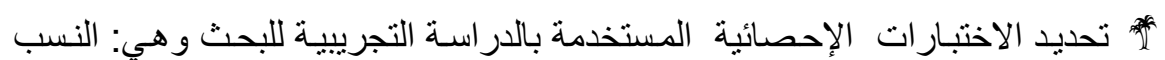

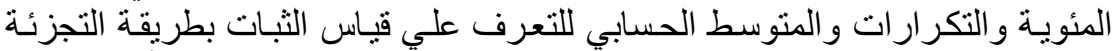

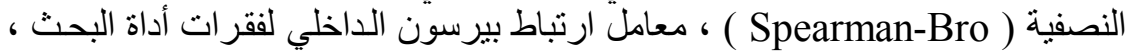

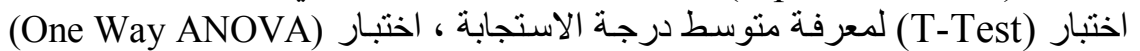

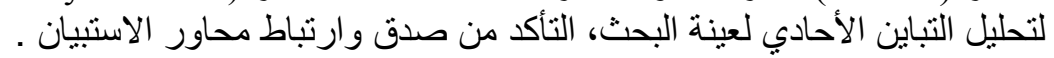

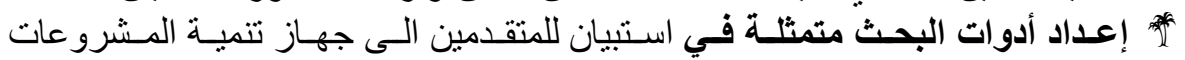

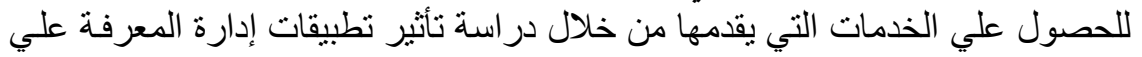

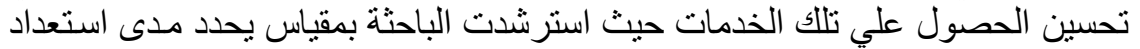

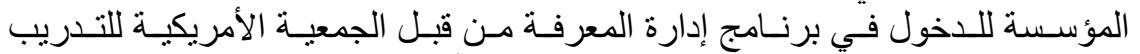

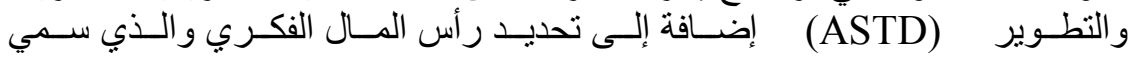

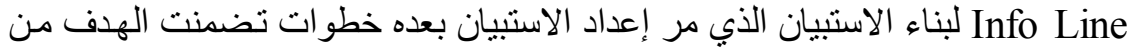

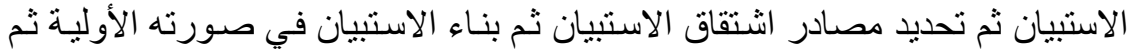

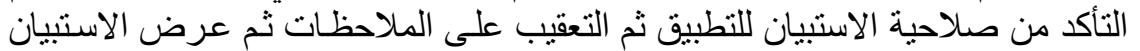

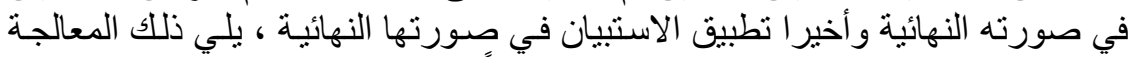

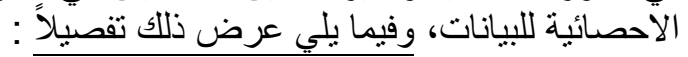

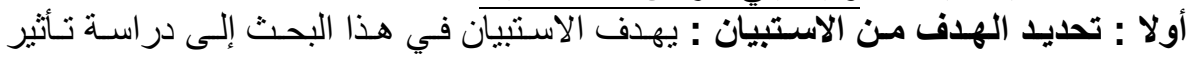

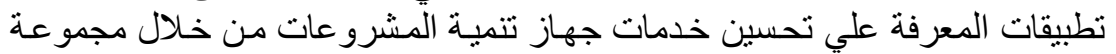

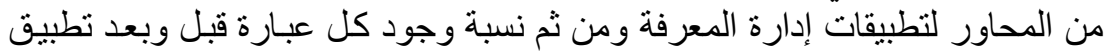

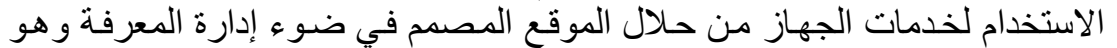

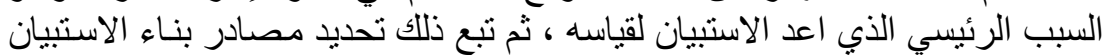

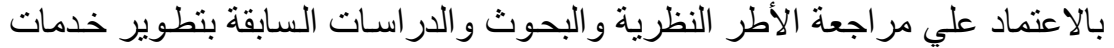

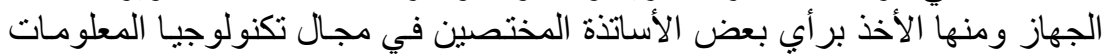

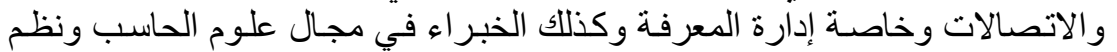

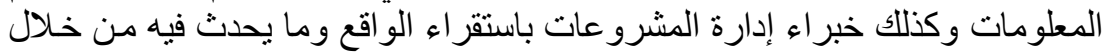

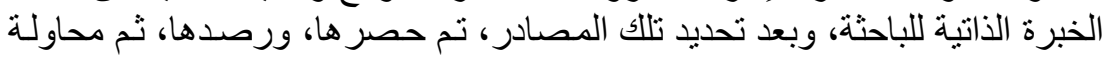

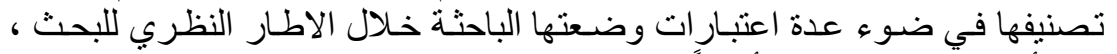

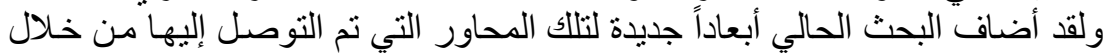

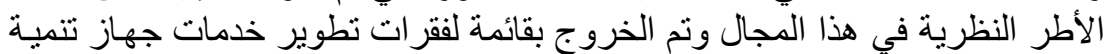

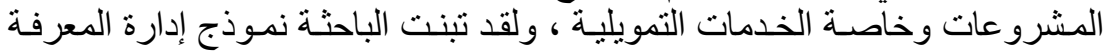
للاستعانة به عند تطبيق البحث وهو ما يوضحه الثنكل التالي :

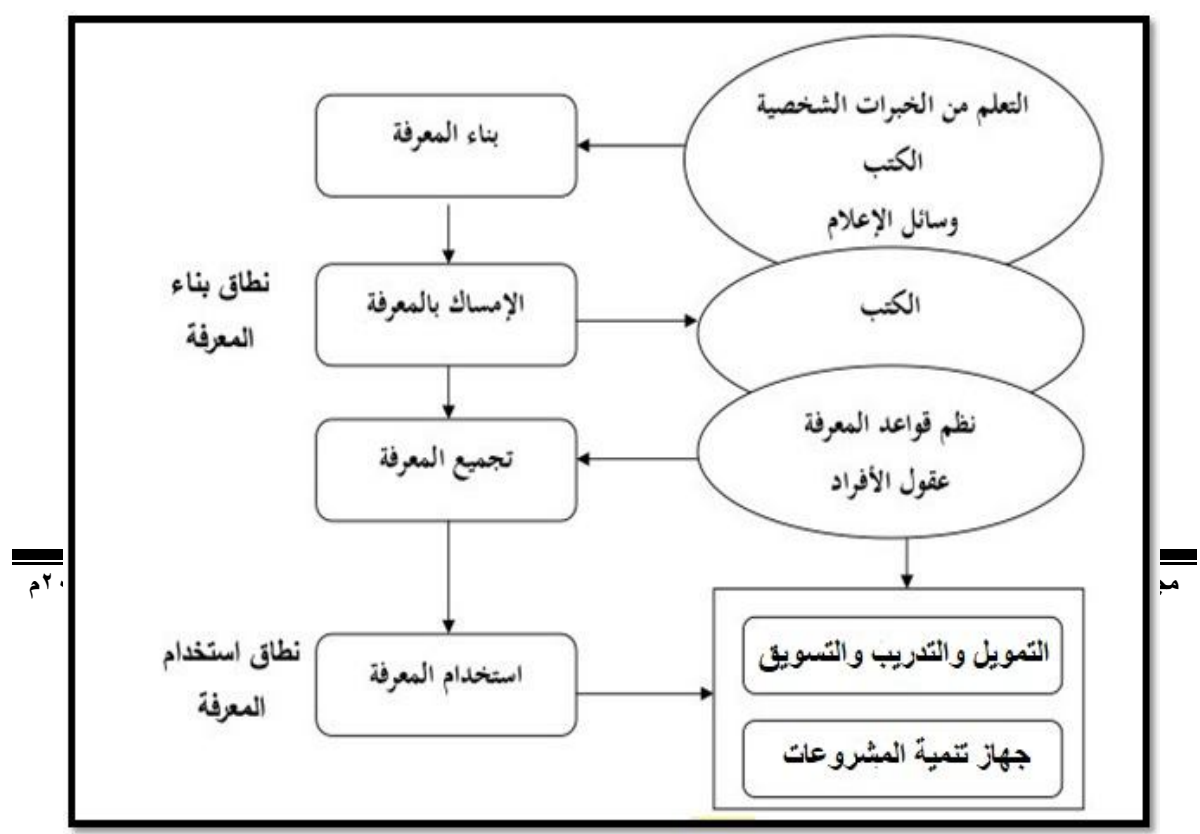




\section{شكل (r) نموذج إدارة المعرفة عند Wiig بن حمودة ، 10 ب بrم}

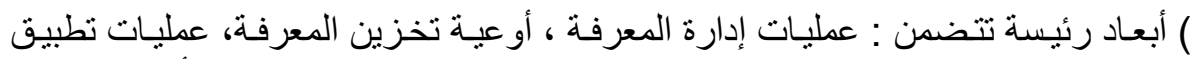

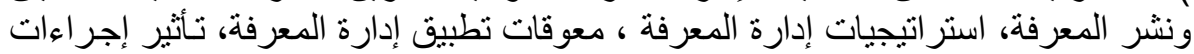

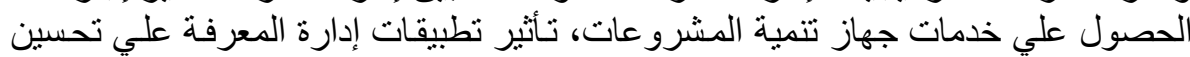

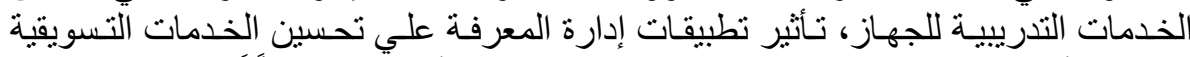

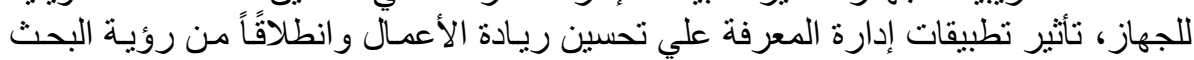

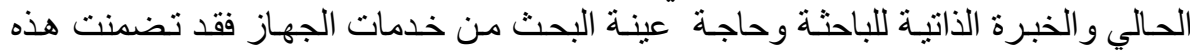

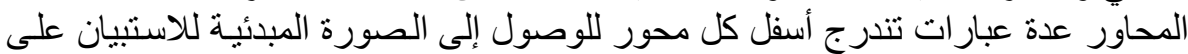

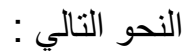

\begin{tabular}{|c|c|c|}
\hline عدد العبارات & المحاور الرئيسية & م \\
\hline 19 & تالأول : عمليـات إدارة المعرفـة : تشخيصها ، اكتسابها، & 1 \\
\hline$T \varepsilon$ & الثاني : أو عية تخزين المعرفة ، المتابعة و الرقابة & $r$ \\
\hline TA & الثعرفة : عمليـات تطبيق ونشر وتقاسم وتوزيع وتحديث & $r$ \\
\hline$\pi$ & الرابع : استر اتيجيات تطبيق إدارة المعرفة و التخطبط لها & $\varepsilon$ \\
\hline 0 & الشـــامس : معوقـات تطبيـق إدارة المعرفـة بجهـاز تنميـة & 0 \\
\hline 11 & 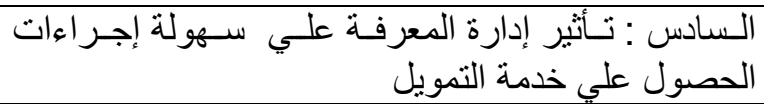 & 7 \\
\hline$\Lambda$ & 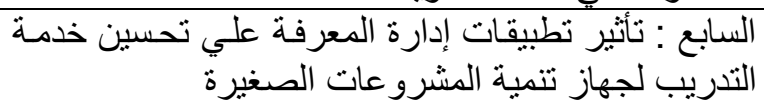 & V \\
\hline 1. & 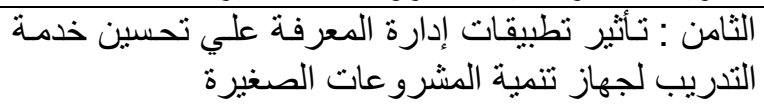 & $\Lambda$ \\
\hline 1. & جهاز تنمية المشرو مفات التئرو الصغيرة الاعمال علي تحسين خدمات & 9 \\
\hline & ITV & 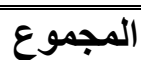 \\
\hline
\end{tabular}




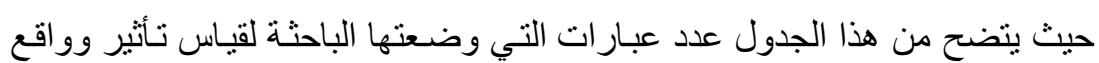

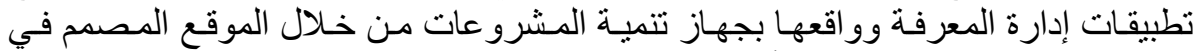

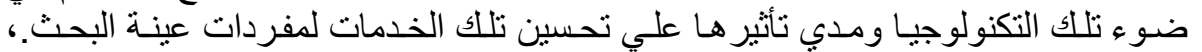

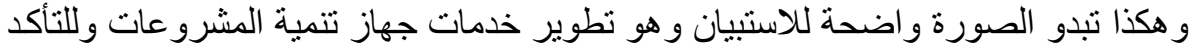

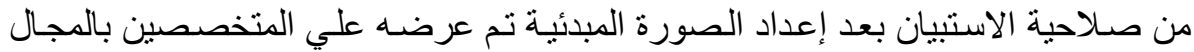

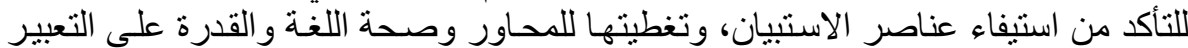

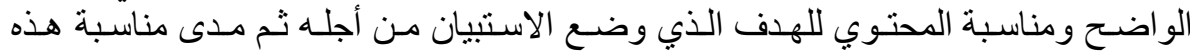

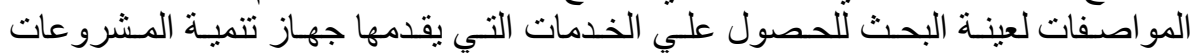
ومدى أهمية هذه نطوير تللك الخدمات ( مهمة - منوسطة الأهمية - غير مهمة ) وذللك علي

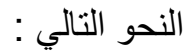

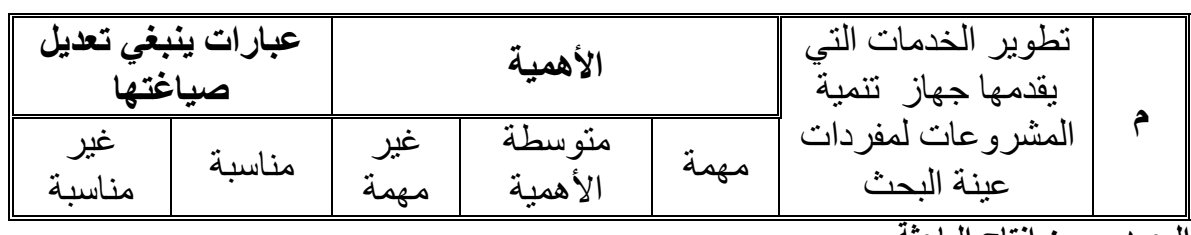

المصدر : من إنتاج الباحثة

نظام التصحيح وتقدير الارجات : حيث تم وضع معيار للتقويم ووضع الدرجات طبقا للأداء

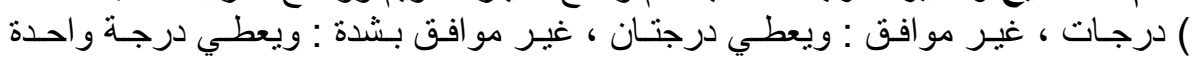
ويتلخص نظام التصحيح في الجدول التالي :

\begin{tabular}{|c|c|c|c|}
\hline 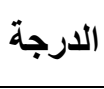 & 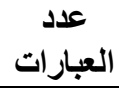 & المحاور الرئيسية & r \\
\hline & & الأول : عمليات إدارة المعرفة : تشخيصها ، اكتسابها ، توليدها & \\
\hline & & الثاني : أوعية تخزين المعرفة ، المتابعة و الرقابة & \\
\hline & & الثالث: عمليات تطبيق ونشر وتقاسم وتوزيع وتحديث المعرفة & \\
\hline & & الر ابع : استر اتيجيات تطبيق إدارة المعرفة والتخطبط لها & \\
\hline & & المشروعـات : معوقــات تطبيــق إدارة المعرفـــة بجهــاز تتميــة & \\
\hline & & السادس : تأثنير إدارة المعرفة علي سـولة إجر اءات الحصول & \\
\hline & & 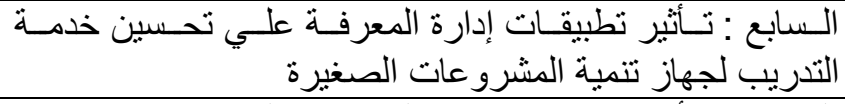 & \\
\hline & & 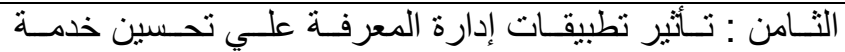 & \\
\hline
\end{tabular}




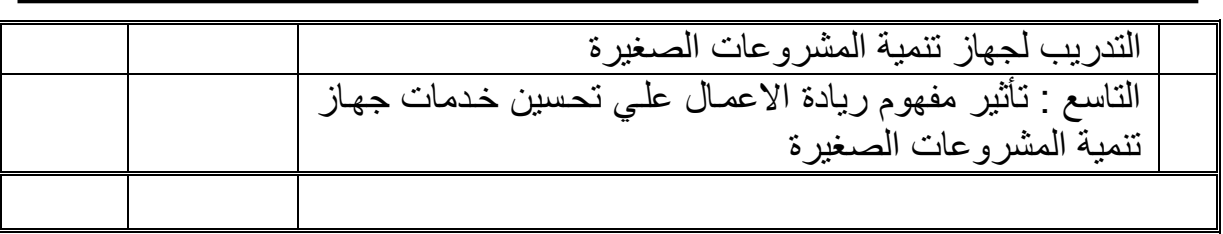

المصدر : من إنتاج الباحثة

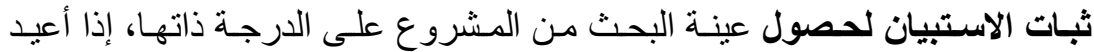

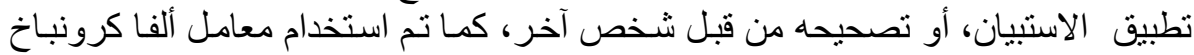

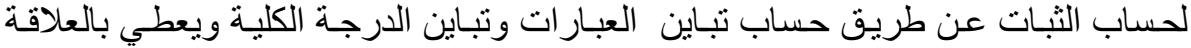

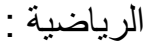

$$
\frac{k}{k \cdot 1} \cdot 1 \cdot \frac{\bullet s_{i}^{2} \cdot}{s_{i}^{2}}
$$

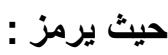

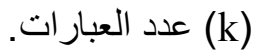

ت • • $\left.s^{2}{ }_{i}\right)$

\begin{tabular}{|c|c|c|c|c|c|}
\hline الثبات معل & التباينة & العبارات & عدد العبارات & البيــان & المحور \\
\hline$\cdot, 91$ & r,00 & $1, r \pi$ & 19 & 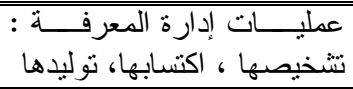 & الأول \\
\hline$\cdot, 97$ & $r, \wedge \Lambda$ & 1,10 & $T \varepsilon$ & 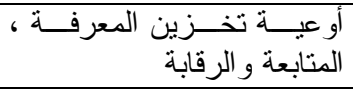 & الثاني \\
\hline$\cdot, \wedge \wedge$ & $r, v V$ & Y,YY & YA & 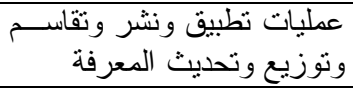 & الثالث \\
\hline$\cdot, 91$ & $r, r)$ & 1,11 & 14 & 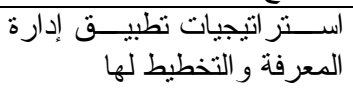 & الرابع \\
\hline$\cdot, \wedge \Gamma$ & $\mid 0, Y)$ & $r, 00$ & 0 & مجهوقات تتمية المشيق إدوارة المعرفة & الخامس \\
\hline$\cdot, 90$ & $r, \mathrm{VV}$ & 1,00 & 11 & 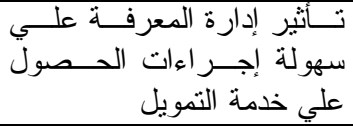 & السادس \\
\hline - 94 & $|0, r|$ & $\{, 11$ & $\Lambda$ & 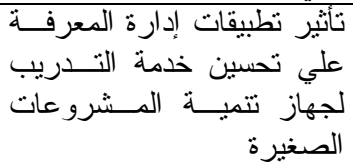 & السابع \\
\hline$\cdot, \wedge \wedge$ & 10,11 & $\varepsilon, \wedge \Lambda$ & 1. & 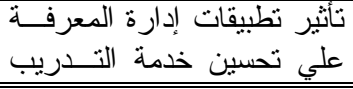 & الثامن \\
\hline
\end{tabular}

$$
\text { (التباين الكلي لمجموع عبار ات الاستبيان. }
$$




\begin{tabular}{|c|c|c|c|c|c|}
\hline & & & & الصغيرة تتميــة المـشروعات & \\
\hline$\cdot, 94$ & $9, r T$ & T, $\leqslant \varepsilon$ & IT & 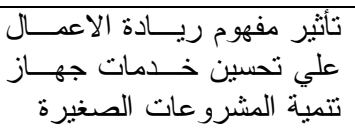 & التاسع \\
\hline$\cdot, 9$. & 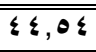 & $11, \varepsilon Y$ & $1 T V$ & الارجةُ الكلية & \\
\hline
\end{tabular}

المصدر : من إنتاج الباحثة

) و هذا يدل أن الاستيان تتمتع بدرجة مناسبة من الثبات تصلح لقياس تطوير خدمات لتبات لجهاز

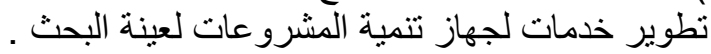

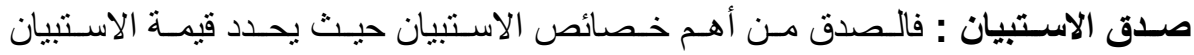

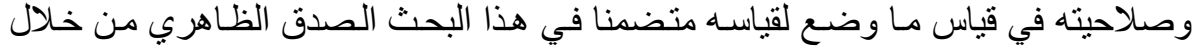

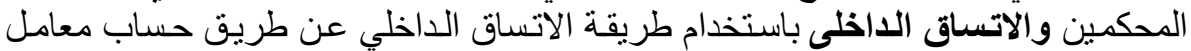

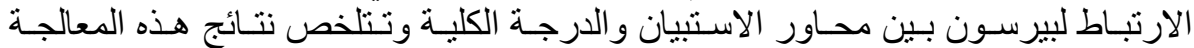

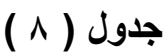

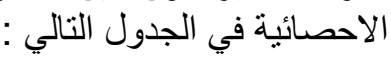

معامل الارتباط بين محاور الاستبيان والارجة الكلية له

\begin{tabular}{|c|c|c|c|}
\hline الدلالة الإحصائية & الالارتباطة & & 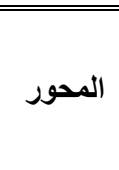 \\
\hline دالـــــة عنـــــ & & توليدهات إدارة المعرفــة : تشخيـصـها ، اكتـــابها، & الأول \\
\hline دالــــة عنــــد & & أو عية تخزين المعرفة ، المتابعة والرقابة & الثاني \\
\hline دالـــــة عنـــــ & & المعرفة عليـات تطبيـق ونـشر وتقاســم وتوزيـع وتحـديث & 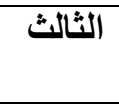 \\
\hline دالـــــة عنــــد & & استر اتيجيات تطبيق إدارة المعرفة والتخطيط لها & 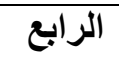 \\
\hline دالـــــة عنــــد & & المعشروقـات تطبيــق إدارة المعرفــة بجهــاز تتميــة & 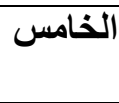 \\
\hline 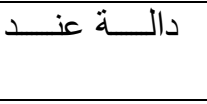 & & 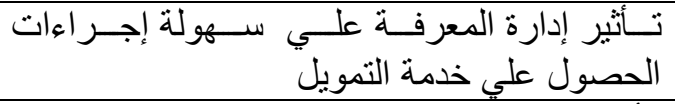 & 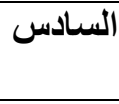 \\
\hline دالــــة عنــــــ & & 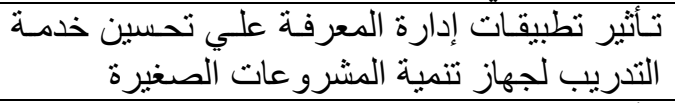 & السابع \\
\hline 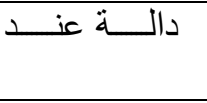 & & 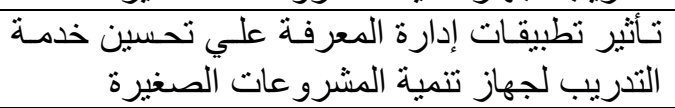 & 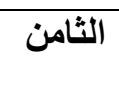 \\
\hline دالــــة عنــــــ & & 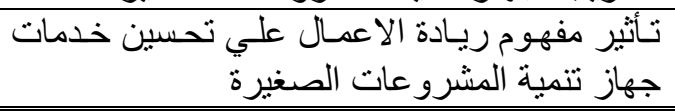 & التاسع \\
\hline
\end{tabular}

المصدر : من إنتاج الباحثة 


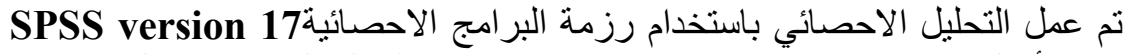

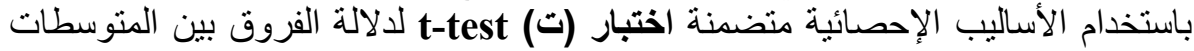

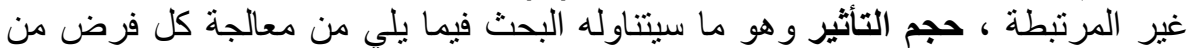
فروض البحث بتحليل استجابات مفردات عينة البحث من المجمو عتين التجريبية و الضابطة فئة

معالجة الفرض الأول للبحث : " لا توجد فروق ذات دلاله إحصائية بين المجموعتين

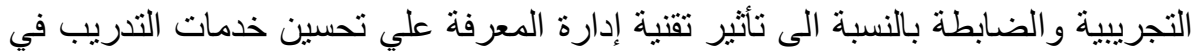

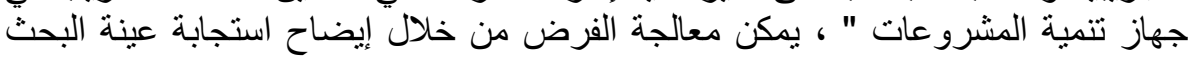
تجاه فقرات الاستبيان الخاصة بالمحور السابع وهو ما بمكن اليضاحه من خلال الجدول

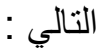

" تأثير تطيقات إدارة المعرفة علي تحسين خدمة التدريب لجهاز تنمية المشروعات الصغيرة "

\begin{tabular}{|c|c|c|c|c|c|c|c|c|c|}
\hline 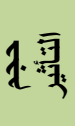 & $\cong$ & $\frac{3}{3} \overline{3}$ & 姜哥 & 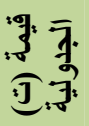 & 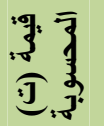 & 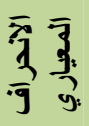 & $\begin{array}{l}\overline{3} \overline{3} \\
3 \\
3\end{array}$ & $\overline{7}$ & 京 \\
\hline \multirow{2}{*}{ كبير } & \multirow{2}{*}{$\cdot v v$} & \multirow{2}{*}{91} & \multirow{2}{*}{$\because 0$} & \multirow{2}{*}{ זד. ז } & \multirow{2}{*}{17.0.} & $Y . Y$ & 10. & 0. & ضابطة \\
\hline & & & & & & $\Lambda . \wedge$ & r.. & 0. & تجريبية \\
\hline
\end{tabular}

المصدر : من إنتاج الباحثة.

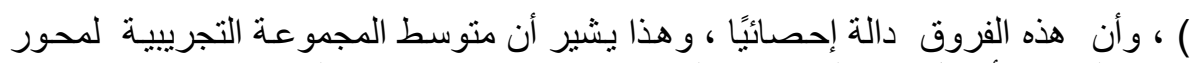

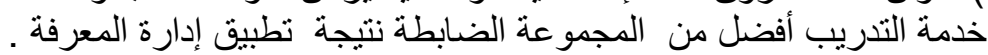

معالجة الفرض الثاني للبحث : " لا توجد فروق ذات دلاله إحصائية بين المجموعتين

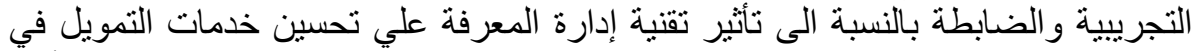

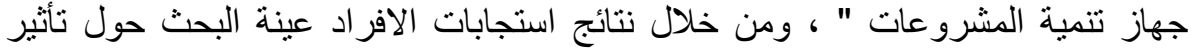

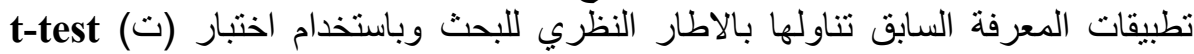

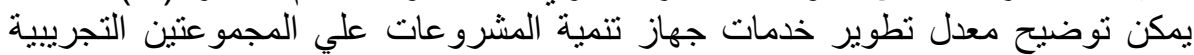

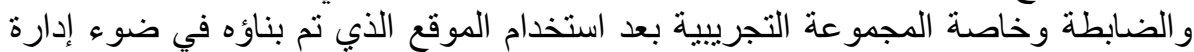

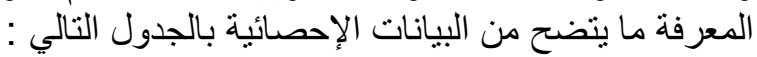

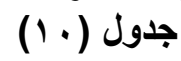

دلالة الفروق بين درجات المجموعتين التجريبية والضابطة في المحور السادس " تأثثير إدارة المعرفة علي سهولة إجراعات الحين الحصول علي خدمة التمويل "

\begin{tabular}{|c|c|c|c|c|c|c|c|c|c|}
\hline 章 & 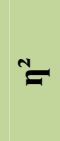 & 交文哥 & 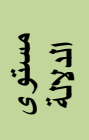 & 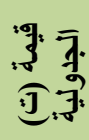 & 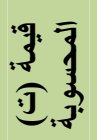 & $\begin{array}{l}\bar{y} \\
\bar{y} \\
\bar{y} \\
\bar{y}\end{array}$ & $\begin{array}{l}\overline{9} \overline{7} \\
3 \\
3\end{array}$ & รุㄱำ & 3. \\
\hline \multirow{2}{*}{ كبير } & \multirow{2}{*}{.99} & \multirow{2}{*}{$9 \wedge$} & \multirow{2}{*}{$\because 0$} & \multirow{2}{*}{ r. } & \multirow{2}{*}{1.0.} & 0.7 & TY.. & 0. & ضابطة \\
\hline & & & & & & $1 \leq .0$ & VY.. & 0. & تجريبية \\
\hline
\end{tabular}

المصدر : من إنتاج الباحثّة. 


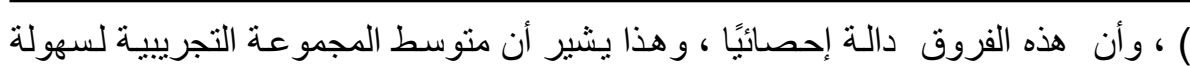

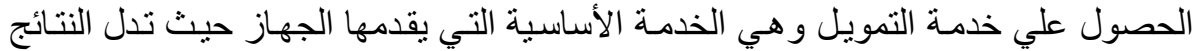
علي تفوق المجموعة التجرييية في الحصول علي خدمة التمويل في وقت التل التيل ومجهود اقل نتيجة استخدام البرنامج القائم علي إدارة المعرفة في العي

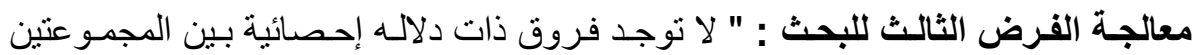

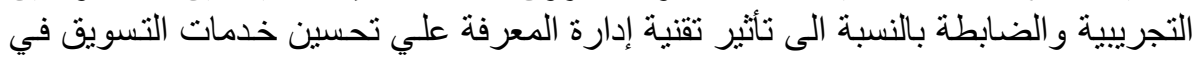

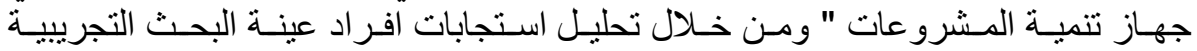

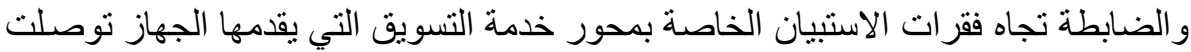

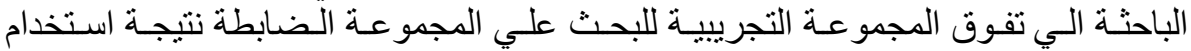
تطبيقات ادارة المعرفة وهو ما يمكن ايضاحه من خلال الجدول التالي :

دلالة الفروق بين متوسطي المجموعتين التجريبية والضابطة في المحور الثامن تأثير تطيقات إدارة المعرفة علي تحسين الخدمات التسويقية لجهاز تنمية المشروعات الفيطية الصغيرة

\begin{tabular}{|c|c|c|c|c|c|c|c|c|c|}
\hline 主 & $=$ & 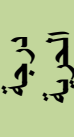 & 青示 & 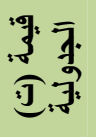 & 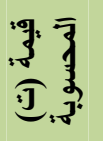 & $\begin{array}{l}\overline{\mathrm{g}} \overline{3} \\
\overline{9} \\
\overline{9}\end{array}$ & 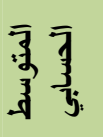 & $\overline{7}$ & $\underset{3}{9}$ \\
\hline \multirow{2}{*}{ كبير } & \multirow{2}{*}{$\because v_{0}$} & \multirow{2}{*}{91} & \multirow{2}{*}{$\because 0$} & \multirow{2}{*}{ r. r } & \multirow{2}{*}{10.10} & $r . \xi$ & 19.0 & 0. & ضابطة \\
\hline & & & & & & $11 . \varepsilon$ & $\varepsilon \cdot 0$ & 0. & تجرييية \\
\hline
\end{tabular}

المصدر : من إنتاج الباحثة.

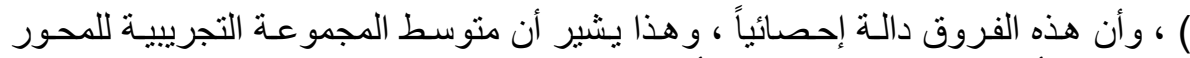

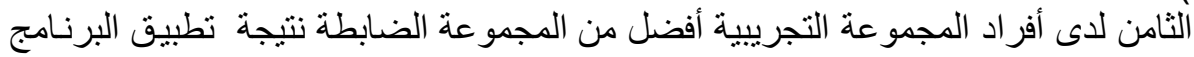

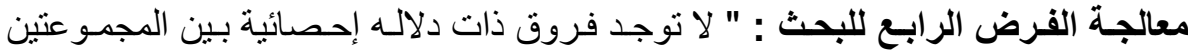

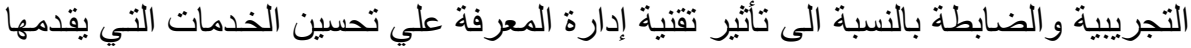
جهاز تنمية المشرو عات " .

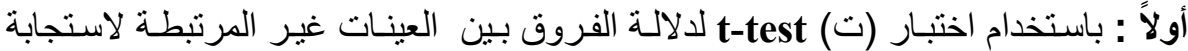

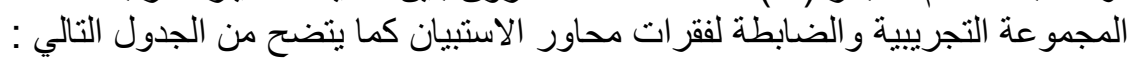

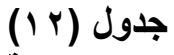
دلالة الفروق بين متوسطي المجموعتين التجريبية والضابطة في الارجة الكلية لاستبيان

\begin{tabular}{|c|c|c|c|c|c|c|c|c|c|}
\hline 章 & $\cong$ & 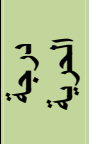 & 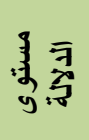 & 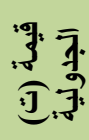 & 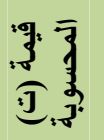 & 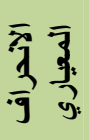 & $\begin{array}{l}\overline{7} \overline{3} \\
3 \\
3\end{array}$ & 承 & 亲 \\
\hline \multirow{2}{*}{ كبير } & \multirow{2}{*}{.90} & \multirow{2}{*}{$9 \wedge$} & \multirow{2}{*}{$\because 0$} & \multirow{2}{*}{ Tr.T } & \multirow{2}{*}{$\leqslant \leqslant . r q$} & $10 . r$ & $r 0.0^{\circ}$ & 0. & ضابطة \\
\hline & & & & & & $\$ 0.1$ & 00.9 & 0. & تجرييية \\
\hline
\end{tabular}

المصدر : من إنتاج الباحثة. 
) وأن هذه الفروق دالة إحصائًًا وهذا ينشبر أن متوسط المجموعة التجريبيـة للارجـة الكلية

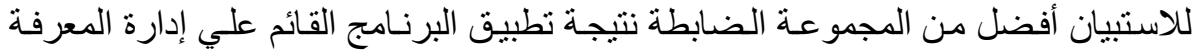
ويمكن توضيح متوسطي المجمو عتين في الدرجة الكلية للاستبيان .

ثانيا : واقع تطبيق إدارة المعرفة لدي جهاز تنمية المشروعات ، فباستخدام اختبار (ت)

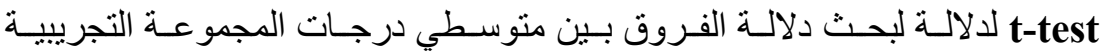

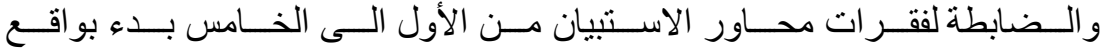
إدارة المعرفة ومعدل تطوير خدمات جهاز تنمية المشرو عات كما يتضح من الأنس الجدول

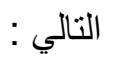

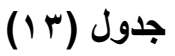

دلالة الفروق بين درجات المجموعتين التجريبية والضابطة في المحور الأول

\begin{tabular}{|c|c|c|c|c|c|c|c|c|c|}
\hline$\frac{\not 1}{3}$ & $\approx$ & 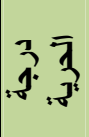 & 予零 & 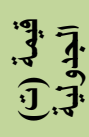 & 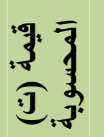 & $\begin{array}{l}\bar{y} \\
\bar{y} \\
\bar{y} \\
\overline{9}\end{array}$ & $\begin{array}{l}\overline{3} \overline{7} \\
3 \\
3\end{array}$ & $\overline{7}$ & $\begin{array}{l}\text { 子. } \\
.9 \\
.9\end{array}$ \\
\hline \multirow{2}{*}{ كبير } & \multirow{2}{*}{$\cdot v \leqslant$} & \multirow{2}{*}{91} & \multirow{2}{*}{$\because 0$} & \multirow{2}{*}{ זיד.Y } & & $0 . r$ & ro.0 & 0. & ضابطة \\
\hline & & & & & & $1 Y .1$ & 17.9 & 0 . & تجرييية \\
\hline
\end{tabular}

المصدر : من إنتاج الباحثة.

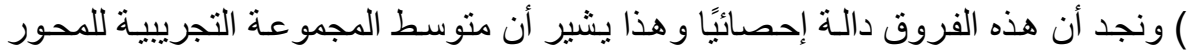

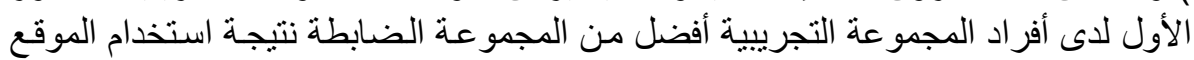

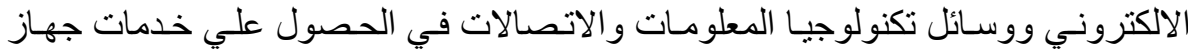

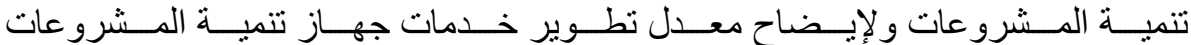
و إيضاح أوعيـة تخزين المعرفة واستجابة المجمو عتين (التجريبية والضابطة) في الجدول

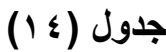

دلالة الفروق بين متوسطي المجموعتين التجريبية والضابطة في اوعية تخزين المعرفة

\begin{tabular}{|c|c|c|c|c|c|c|c|c|c|}
\hline$\frac{1}{1}$ & $\cong$ & $3 \overline{7}$ & 桑勇 & 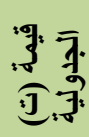 & 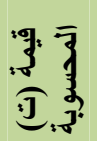 & $\begin{array}{l}\bar{y} \\
\bar{y} \\
\bar{y} \\
\bar{y}\end{array}$ & $\begin{array}{l}\overline{9} \overline{3} \\
3 \\
3\end{array}$ & จุㄱ & $\begin{array}{c}\frac{9}{3} \\
.9\end{array}$ \\
\hline \multirow{2}{*}{ كبير } & \multirow{2}{*}{.91} & \multirow{2}{*}{91} & \multirow{2}{*}{$\because 0$} & \multirow{2}{*}{ זד. } & \multirow{2}{*}{ ro. 0.} & \&. & $00_{0}$. & 0. & ضابطة \\
\hline & & & & & & 11.2 & 1.8. & 0. & تجريبية \\
\hline
\end{tabular}

المصدر : من إنتاج الباحثة.

) ، وأن هذه الفروق دالة إحصائباً ، وهذا يشير إلى أن متوسط المجموعة التجرييية للمحور 


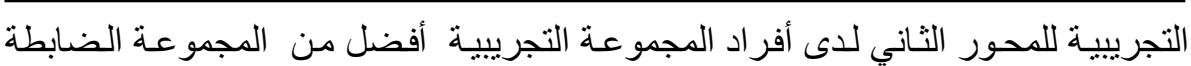

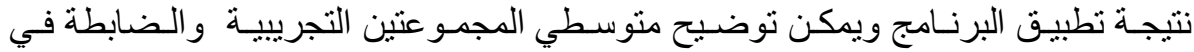

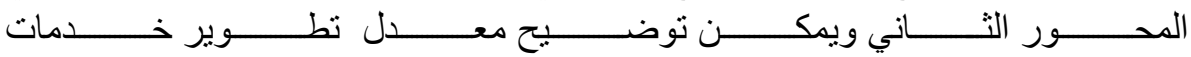

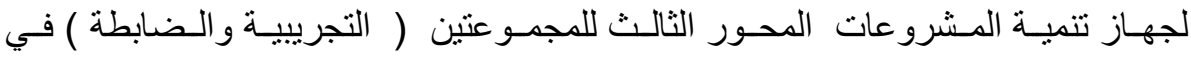

$$
\text { جدول (10) }
$$

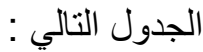

دلالة الفروق بين متوسطى المجموعتين التجريبية والضابطة في المحور الثالث.

\begin{tabular}{|c|c|c|c|c|c|c|c|c|c|}
\hline 竞 & $\approx$ & 零 $\overline{\frac{7}{3}}$ & 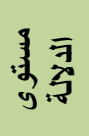 & 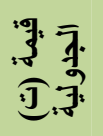 & 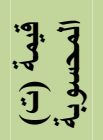 & $\begin{array}{l}\bar{y} \\
\bar{y} \\
\bar{y} \\
\bar{y}\end{array}$ & 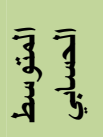 & $\overline{7}$ & 子. \\
\hline \multirow{2}{*}{ كبير } & \multirow{2}{*}{$\because 9}$. & \multirow{2}{*}{91} & \multirow{2}{*}{$\because 0$} & \multirow{2}{*}{ r. } & \multirow{2}{*}{ YY.O. } & 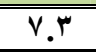 & OY.• & 0. & ضابطة \\
\hline & & & & & & 10.1 & $\| 1 r_{0}$ & 0. & تجريبية \\
\hline
\end{tabular}

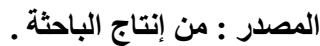

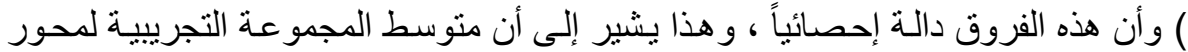

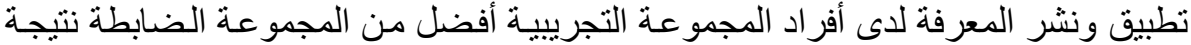

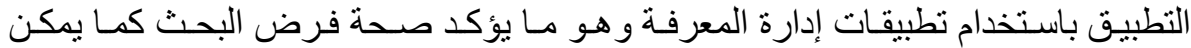

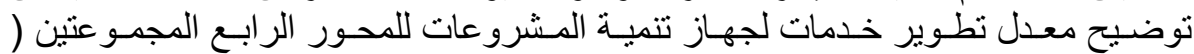
التجرييية و الضابطة ) في الجدول التالي :

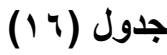

دلالة الفروق بين متوسطي المجموعتين التجريبية والضابطة

حول استر اتيجيات إدارة المعرفة التجرئ

\begin{tabular}{|c|c|c|c|c|c|c|c|c|c|}
\hline 竞 & $\cong$ & 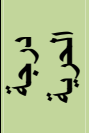 & 予弯 & 羿承 & 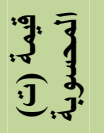 & 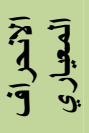 & 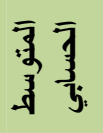 & $\overline{7}$ & 文. \\
\hline \multirow{2}{*}{ كبير } & \multirow{2}{*}{$\cdot \wedge \wedge$} & \multirow{2}{*}{$9 \wedge$} & \multirow{2}{*}{$\because 0$} & \multirow{2}{*}{ זד.ץ } & \multirow{2}{*}{$r \cdot .1$} & r.9.9 & $r \varepsilon_{.}$ & 0. & ضابطة \\
\hline & & & & & & 9.0 & OY.V & 0. & تجرييية \\
\hline
\end{tabular}

المصدر : من إنتاج الباحثة.

) ، وأن هذه الفروق دالة إحصائياً ، وهذا يشير إلى أن متوسط المجموعـة التجريبيـة أفضل

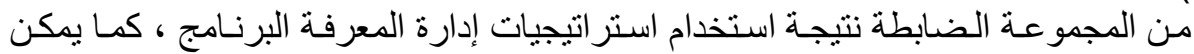

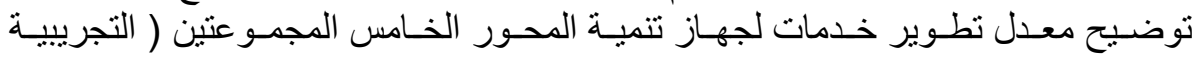
والضابطة ) في الجدول التالى :

جدول (IV)

دلالة الفروق بين درجات المجموعتين التجريبية والضابطة في المحور الخامس 


\begin{tabular}{|c|c|c|c|c|c|c|c|c|c|}
\hline 竞 & $=$ & 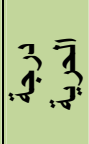 & 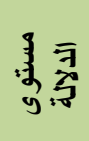 & 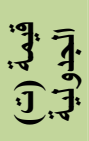 & 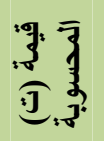 & $\frac{\bar{y}}{\bar{y}} \frac{\overline{3}}{9}$ & 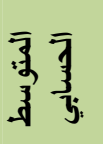 & $\overline{7}$ & 亲. \\
\hline \multirow{2}{*}{ كبير } & \multirow{2}{*}{.$v$. } & \multirow{2}{*}{91} & \multirow{2}{*}{$\because 0$} & \multirow{2}{*}{ זד.ז } & \multirow{2}{*}{$1 . .9}$. & Y.V & $9 . \cdot$ & 0. & ضابطة \\
\hline & & & & & & 8.1 & $r \cdot$. & 0. & تجرييية \\
\hline
\end{tabular}

المصدر : من إنتاج الباحثة .

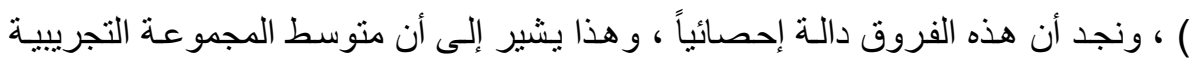
للمحور الخامس لدى أفراد المجموعة التجريبية أفضل من المجموعة الضابطة نتيجة نطبيق النيق

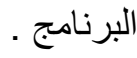

معالجة الفرض الخـامس للبحث : " لا توجد فروق ذات دلاله إحصائية بين المجمو عتين

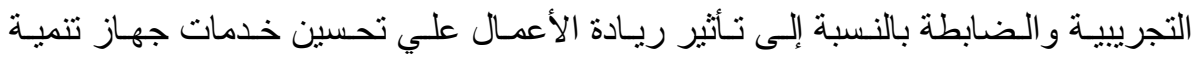

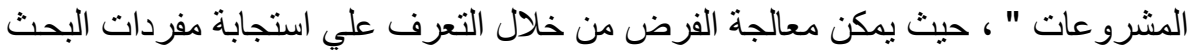

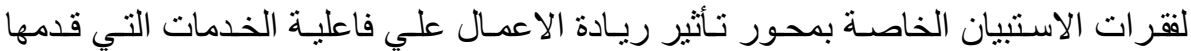
جهاز تتمية المشروعات كما يتضح من الجدول التالي : الأيل

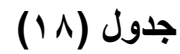

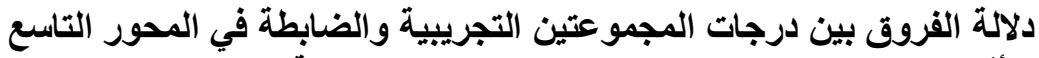

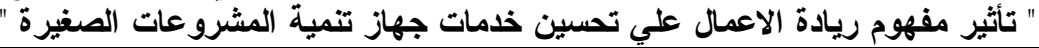

\begin{tabular}{|c|c|c|c|c|c|c|c|c|c|}
\hline 主 & $\cong$ & 交交 & 寻弯 & 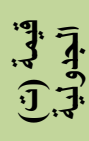 & 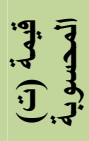 & $\begin{array}{l}\overline{7} \bar{y} \\
\overline{9} \\
\overline{9}\end{array}$ & $\begin{array}{l}\overline{3} \overline{7} \\
3 \\
3 \\
3\end{array}$ & $\overline{7}$ & 京 \\
\hline \multirow{2}{*}{ كبير } & \multirow{2}{*}{.04} & \multirow{2}{*}{$9 \wedge$} & \multirow{2}{*}{$\because \bullet$} & \multirow{2}{*}{ r. } & \multirow{2}{*}{18.1} & r.V & 11.0 & 0. & ضابطة \\
\hline & & & & & & 9.9 & $r 9.0$ & 0. & تجريبية \\
\hline
\end{tabular}

المصدر : من إنتاج الباحثة

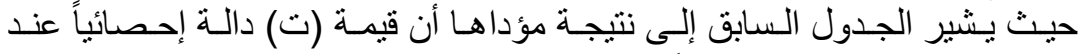

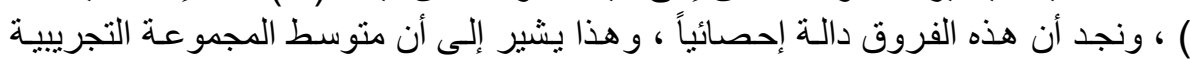

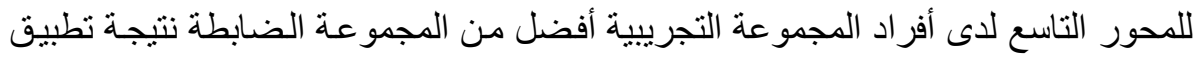

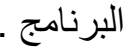

\section{خلاصة نتائج البحث :}

مما سبق ومن معالجة فروض البحث ومن محاور الاستبيان التسعة ومن الجداول

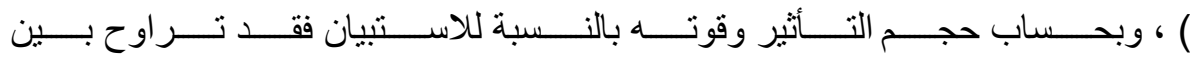
\%) من التأثير يرجع إلي المعالجة القائمة علي البرنامج القائم علي إدارة المعرفة كما تتفق

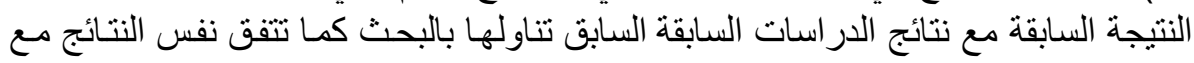
الاطار النظري للبحث و الذي تناول تفصيليا الذي تقوم بـه إدارة المعرفة بتطبيقاتها المختلفة 
و الذي تناول تفصيليا الذي تقوم بها إدارة المعرفة بتطبيقاتها المختلفة علي منظمات الاعمال

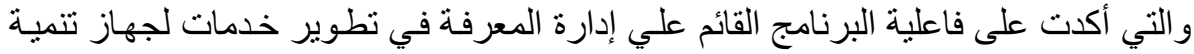

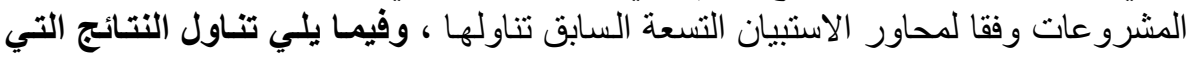

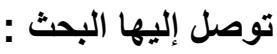

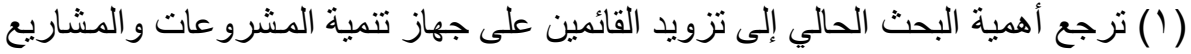

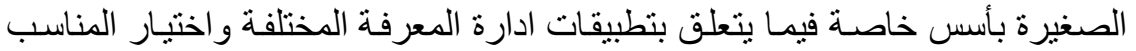

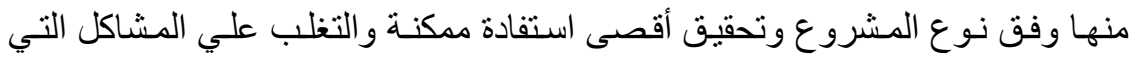

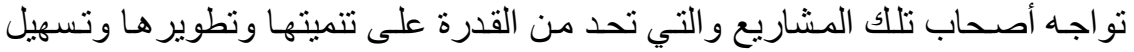

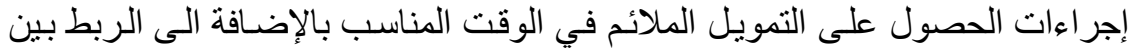

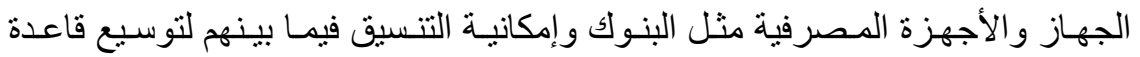

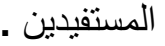

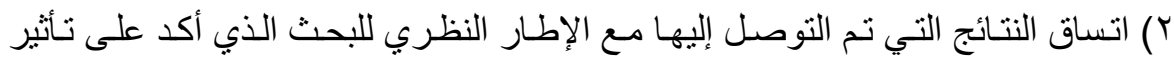

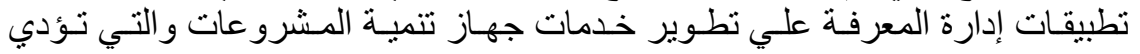

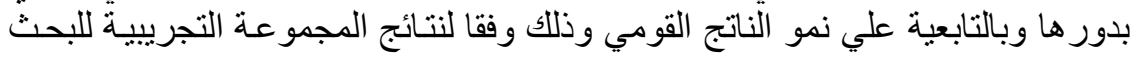

(T) توظيف تقنية إدارة المعرفة أدي إلى التغلب علي الكثير من المشكلات التي تقف حائلا

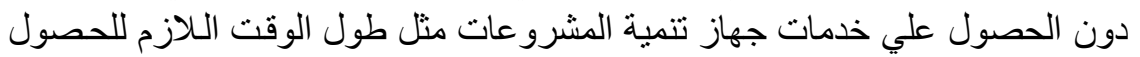

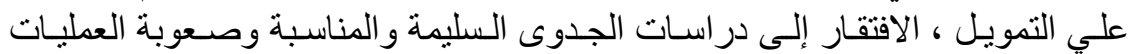

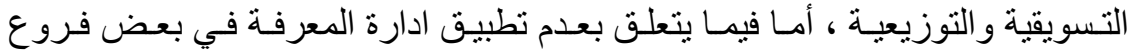

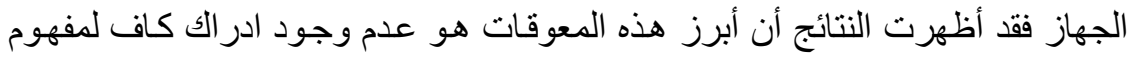

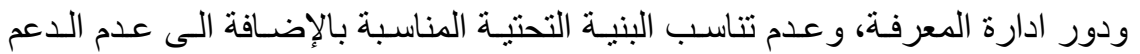
الكافي من الإدارة العليا لعمليات ادارة المعرفة .

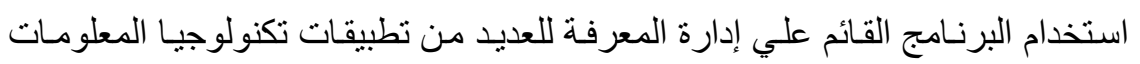
و الاتصـالات المتنوعـة والمتعددة مثل البريد الإلكترونى ، التطبيقات المكتبيـة ، إنتـاج

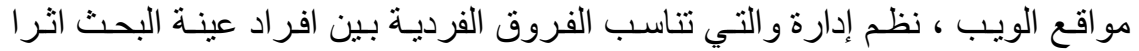
إيجابا علي الاستفادة الكاملة من خدمات الجهاب الجهاز

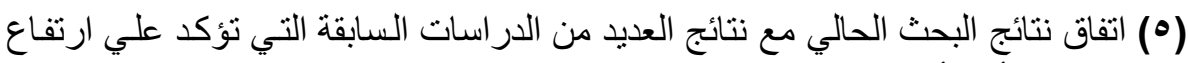

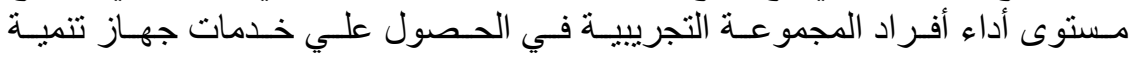

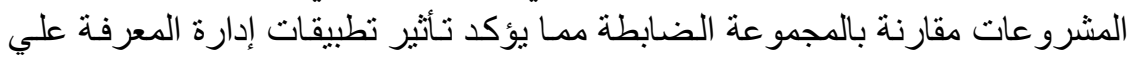
سهولة الحصول علي تللك الخدمات .

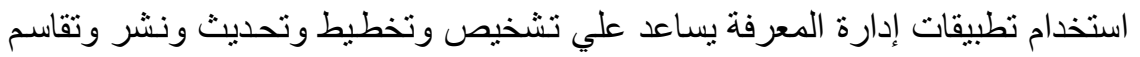
وتوزيع وتوليد و اكتساب وتنظيم وتخزين واسترجاع وتنفيذ المعرفـة والرقابـة علي

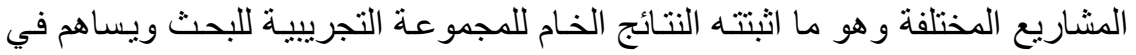

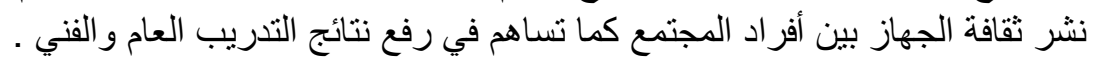
توصيات البحث : تلنئ في ضدوء النتائج التي توصلت إليها الباحثة من خلال الإطسار النظري والمعالجـة

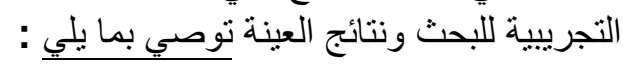




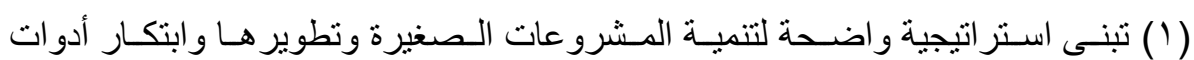

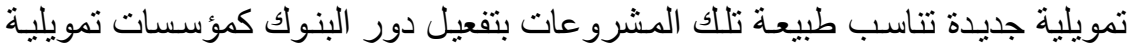

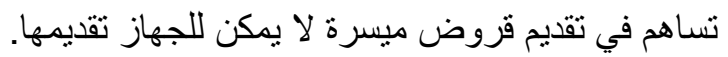

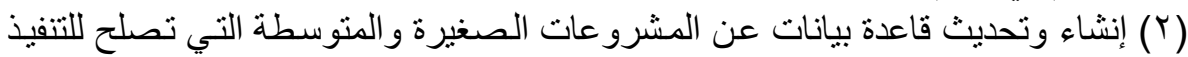

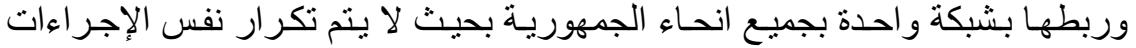

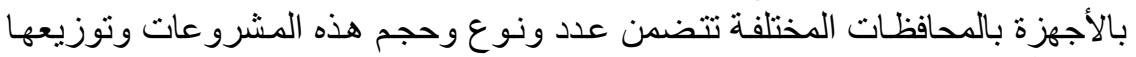

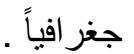

(r) التوسع في استخدام تقنية المعرفة في المؤسسات الأخرى وتطوير إمكانية الاستفادة منها .

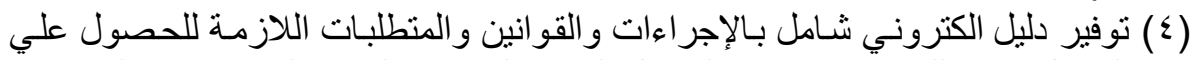

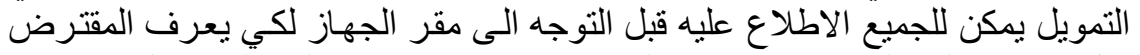

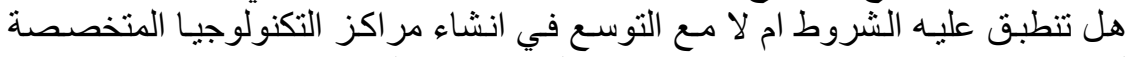

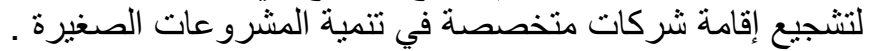

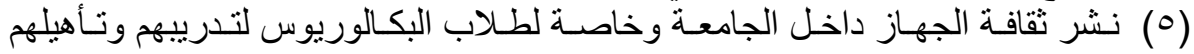

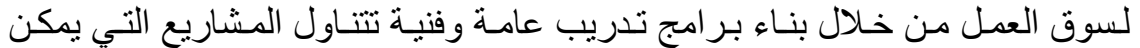

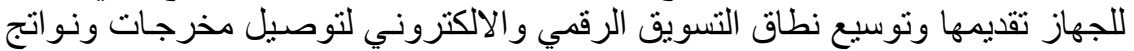

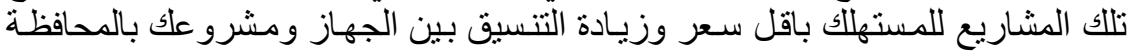

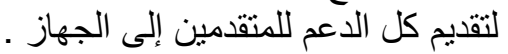




\section{المراجـح}

، القاهرة ، مطابع مؤسسة الأهرام . ، دار الوفاء للطباعة و النشر ، إربد ، الأردن . ، - مالم الكتاب الحديث ، إربد ، الأردن . ، عالم الكتب الحديث ، إربد ، الأردن .

) ، التأمينات الاجتماعية و العاملين بالمشروعات الصغيرة و المتوسطة ، منظمـة العمل .

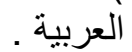
) ، التمكين الإداري للقيادات التربوية برياض الأطفال وعلاقته بممارسة عمليات إدارة

) ، نحـو رؤيسة و اضـحة لمتطلبـات البنيـة التحتيـة لإدارة المعرفـة لمنظمـات الأعمـال العربية ) ، استر اتيجيات إدارة المعرفة : در اسة تحليلية في مؤسسات المعلومات العراق .

) ، و اقع إدارة المعرفة في الهيئة اليمنية للمواصفات و المقاييس وضبط الجودة ودور هـا

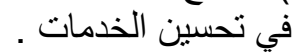

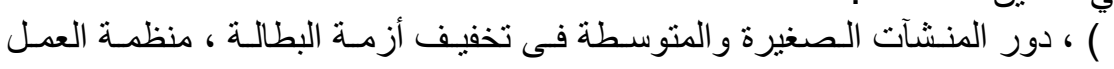

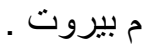
) : تنمية الموارد البشرية بوزارة التربية و التعليم في سلطنة عمـان في ضوء مدخل

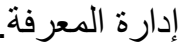
) ، إدارة المعرفة ، دار صفاء للنشر والتوزيع ، الطبعة الأولى ، عمان ، الأردن .

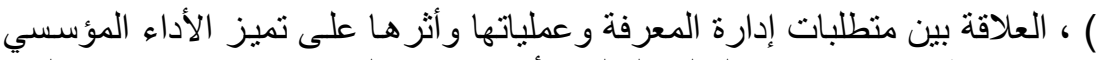

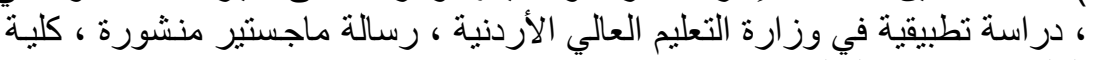

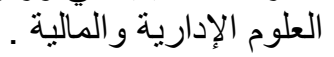

هـ) ، التحول إلى مجتمع المعرفة ، السعودية ، الرياض ، مطابع جامعة الملك سعود

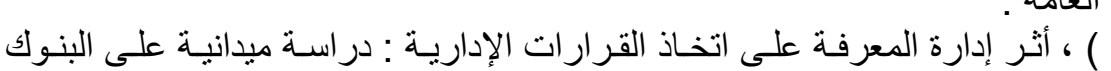

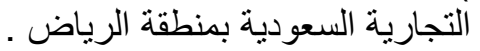
) ، أثنر إدارة المعرفة في تحقيق الميزة التنافسية بـالتطبيق على القطاع المصرفي . 
) ، و اقع تطبيق إدارة المعرفة في ضوء التحو لات المعاصرة في الجامعات السعودية

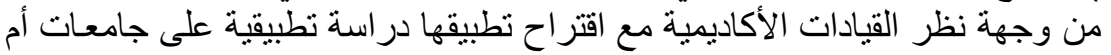
) ، أثر إدارة المعرفة لتحسين الأداء الوظيفي للعاملين ، دراسة حالة لشركة سـابك .

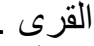
) ) ، العلاقة بين استخدام مدخل إدارة المعرفة و الأداء .

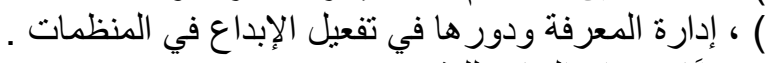

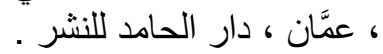

) ، إدارة المعرفة ودور ها في تعزيز إبداع منظمات الأعمال .

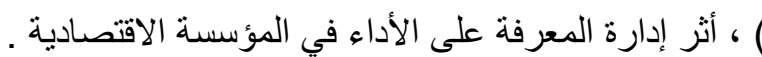

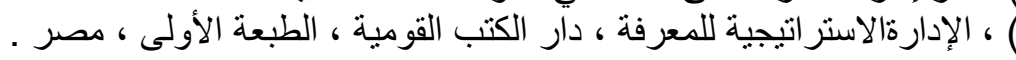

$$
\text { ، ب الوراق للنشر ، عمان ، الأردن . }
$$

) ، الإدارة والمعرفة الالكترونية : الاستراتيجيات ، الوظائف ، دار اليازوري ،

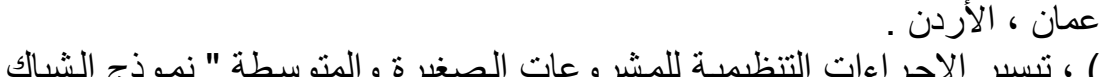

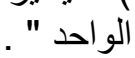
) ، دور إدارة المعرفـة في ميـزة تحقيـق تنافسية : در اسـة تطبيقيـة في المـصـارف

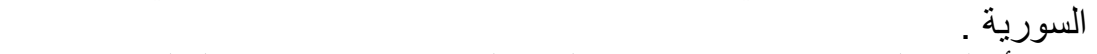
) ، الأساليب المعرفية و علاقتها باتخاذ القرار لدى مديري مدارس التعليم الإعدادي

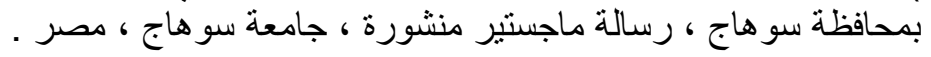

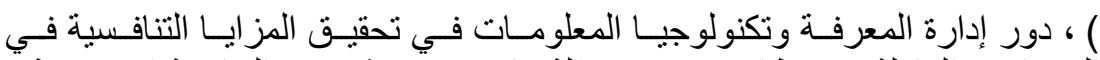

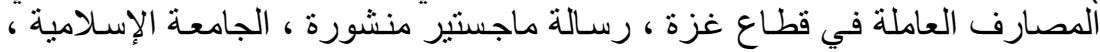

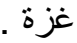
) ، إدارة المعرفة و إمكانية تطبيقها في الجامعات السعودية ، رسالة دكتور اه منشورة

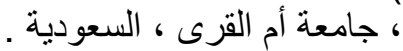

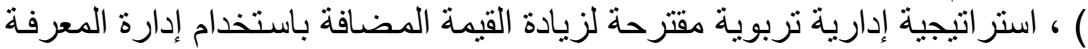

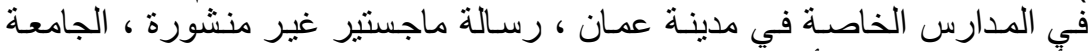

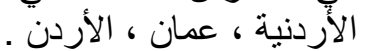

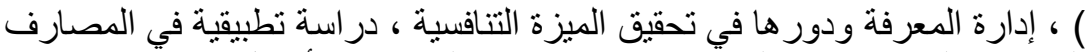

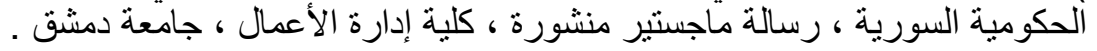

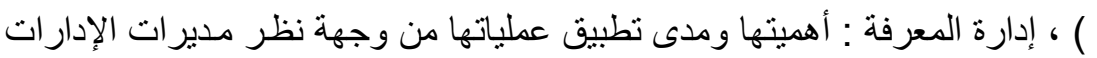

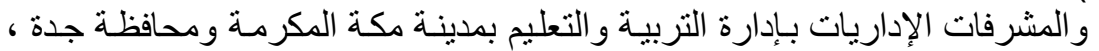

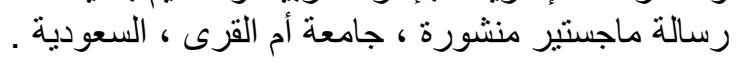

) ، ، الثقافة التنظيمية وعلاقتها بإدارة المعرفة في جامعة الأقصى بغزة من وجهة نظر 


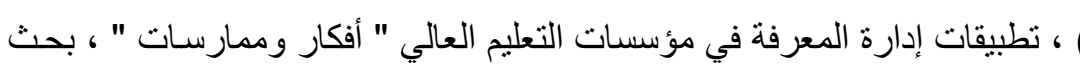

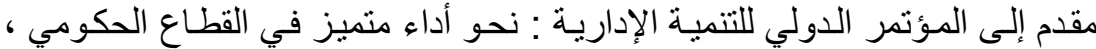

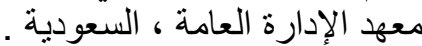

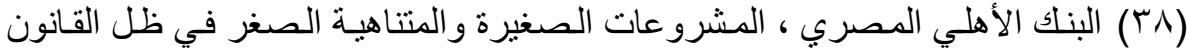

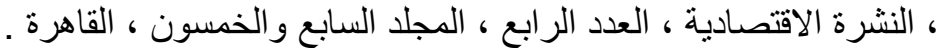

) ، إدارة المعرفة وتطوير المنظمات الطموحات و التحديات ، مجلة الإدارة العامـة ،

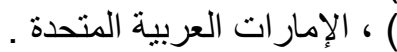

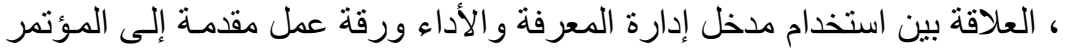

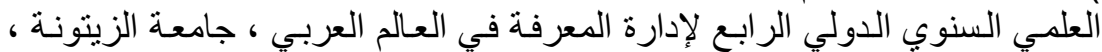

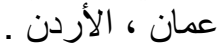

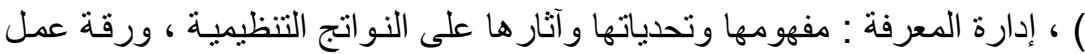

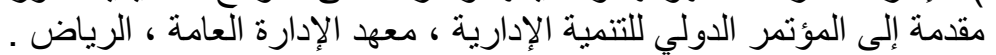

) ، تطوير إدارة التعليم الجامعي المصري في ضوء مدخل إدارة المعرفة : دراسـة تحليلية ) ، اثر ممارسة عمليات إدارة المعرفة على تحقيق ضمان جودة خدمات المعلومات :

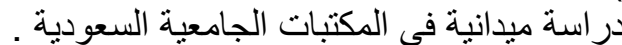
) ، خلق القيمة من خلال إدارة المعرفة داخل المؤسسة . الجزائر : جامعة حسيبة بن من

http://dspace.univ-

chlef.dz:8080/jspui/bitstream/handle/123456789/420/\%D8\%A8\%D9

\%86\%20\%D8\%AD\%D9\%85\%D9\%88\%D8\%AF\%D8\%A9\%20\%D9

\%8A\%D9\%88\%D8\%B3\%D9\%81.pdf?sequence=1\&isAllowed=y ) ، اتجاهات معاصرة في إدارة المعرفة . عمّان : دار صفاء للنشر و التوزيع .

) ، إنتاج ومشاركة المعرفة في المؤسسة : الرهان الجديد لإدارة الموارد البشرية .

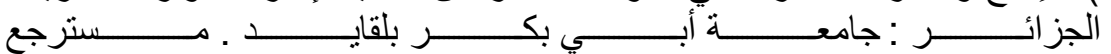

م 6

http://dspace.univ-tlemcen.dz/bitstream/112/2877/1/\%20BELGOUM-:

FARID.Doc.pdf

) ، مستوى تطبيق إدارة المعرفة و أثره على الأداء باستخدام ACP و التحميل

م 6

https://pmb.univ-saida.dz/busegopac/doc_num.php?explnum_id=258:

) ، إدارة المعرفة ( المفاهيم الاستر اتيجيات والعمليات ) ـ عمّان : مؤسسة الورّاق .

(49) Biclawski , L \& Met calf , D (2003) creating clearning: Intergrating Knowledge. Performance support and online learning. Amherst, MA : HRD press. 
(50) Kanges , Lisa Marie (2006) An assessment of the relationship between organizational culture and cantinuavs. Knowledge management initiatives. U.S.A. http: //proquest.umi.com/pqdweb.UMI NUMBER.3196728.

(51) Dalkir, Kimiz. (2005) Knowledge Management In Theory and Practice. McGill University.UK. Retrieved on 25/7/2017, from: https://dianabarbosa.files.wordpress.com/2009/03/knowledgemanagement-kimiz-dalkir.pdf

(52) Keeley, E. (2004). "Institutional Research as the Catalyst for the Extent and effectiveness of Knowledge management Practices in Improving planning and Decisions Making in Higher Education Organization". U.S.A,http: //proquest.umi.com/pqdweb.

(53) James W.Dean,Jr., Mark P.Sharfam(2006) Does Decision process Matter ? A Study of Strategic Decision_making Effectiveness, The Academy of Management Journal, Vol.39, No.2.

(54) Hill; \& Jones, G (2006) " Strategic Management Theory, New York.

(55) Keyser, Richard Lewis (2004): Assessing The Relationship Between Knowledge management And Plant Performance At The Tennessee Valley Authority, Doctor thesis, The University of Alabama in Huntsville.

(56) Al-Mahrouq, M \& Magableh,(2007) I. Role of the Banking Sector in Microfinance and SMEs Development. A paper presented in the conference on "Small Businesses: an effective tool in Fighting Poverty". Held in Yarmouk University- Jordan, July

(57) Magableh, I \& Al-Mahrouq, M. Small and Medium Enterprises (SMEs): Their Definitions, Characteristics, Importance, and Obstacles. A paper presented in the conference on "Small Businesses: an effective tool in Facing Poverty". Held in Yarmouk University-Jordan, July 29-3.

(58) Duffy, Jan (2001) . Knowledge Management: To Be or Not to Be. Information Management Journal, Jan 2001.

(59) Marquardt, Michael J. (2002) Building the learning Organization . Davis-Black Publishing Company, USA. Retrieved on 25/7/2017, from: http://ebook.umaha.ac.id/EBOOK\%20ABOUT\%20ORGANIZATION,\%20MANAGEMENT\%20\&\%20 LEADERSHIP/ORGANIZATION\%20_\%20LEARNING\%20ORGANIZATI ON/BUILDING\%20THE\%20LEARNING\%20ORGANIZATION\%20\%5B Michael\%20J.\%20Marquardt\%5D.pdf

(60) Wiig Karl M(1993). Knowledge Management Foundations: thinking about thinking-How people and Organizations Create, 
Represent and use Knowledge. USA, Sehema Press. Retrieved on 25/7/2017, from:

http://www.academia.edu/19382981/Knowledge_Management_Foundations ___Thinking_about_Thinking__

_How_People_and_Organizations_Create_Represent_and_Use_Knowledge (61) The World Bank (2009), Word Development Indicators. 


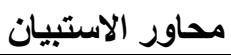

\begin{tabular}{|c|c|c|c|c|c|}
\hline 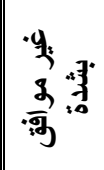 & 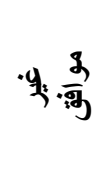 & $\frac{7}{7}$ & के & 高 & 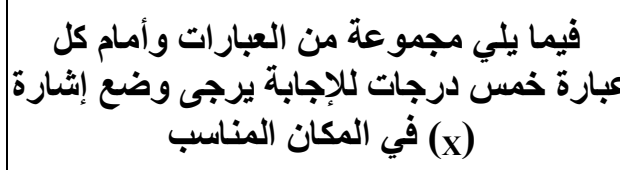 \\
\hline
\end{tabular}

(1) عمليات إدارة المعرفة : تشخيصها ، اكتسابها، توليدها ....

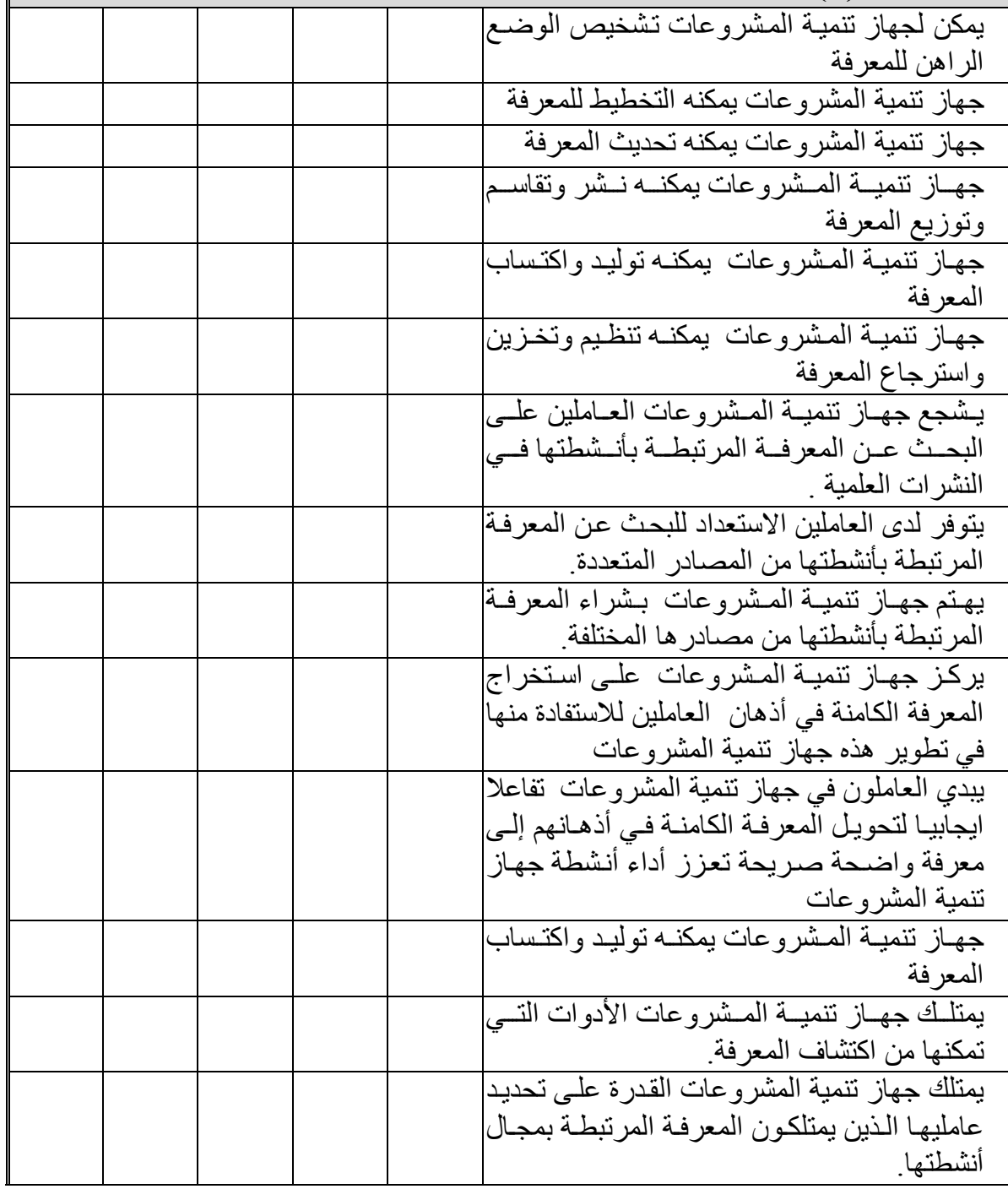




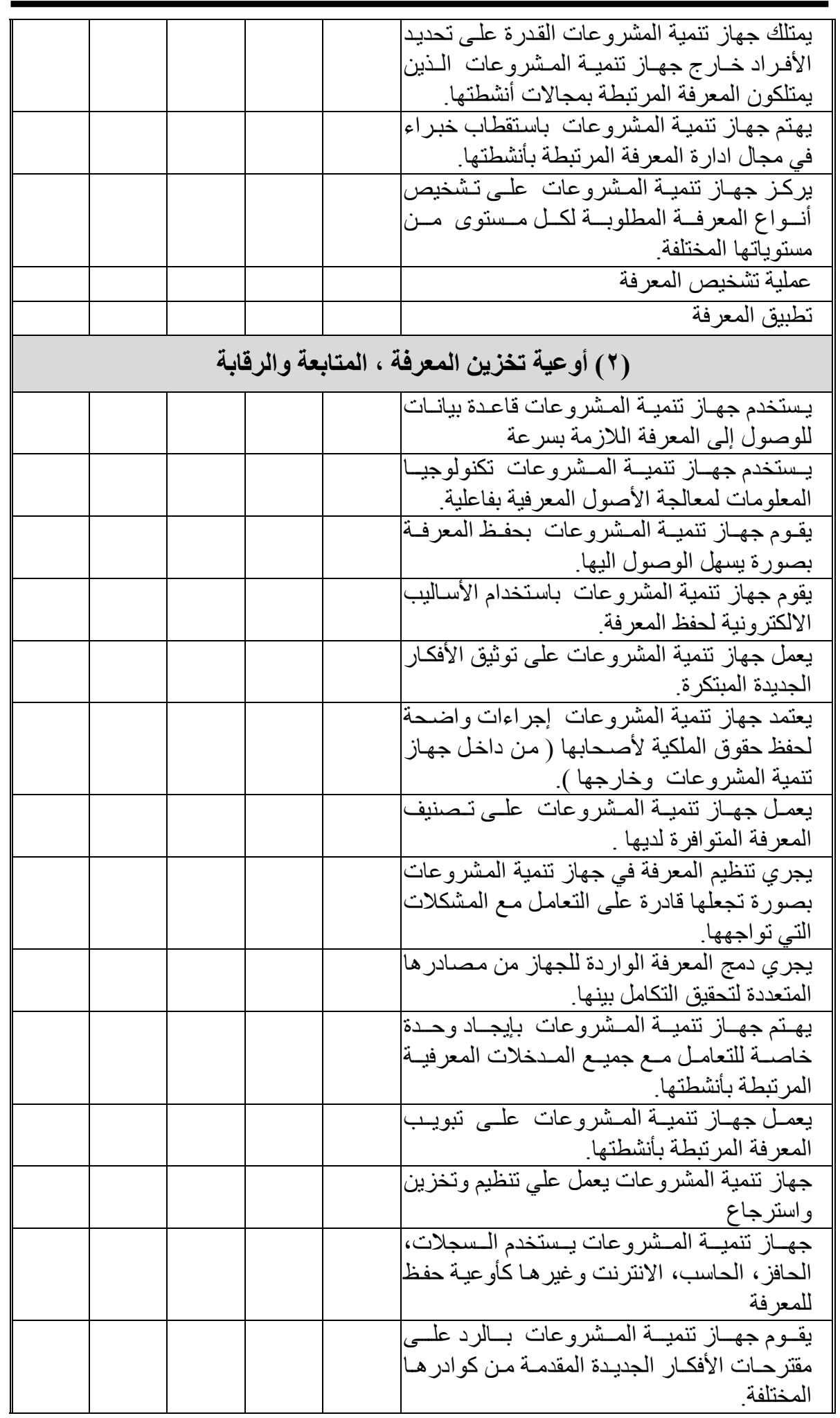




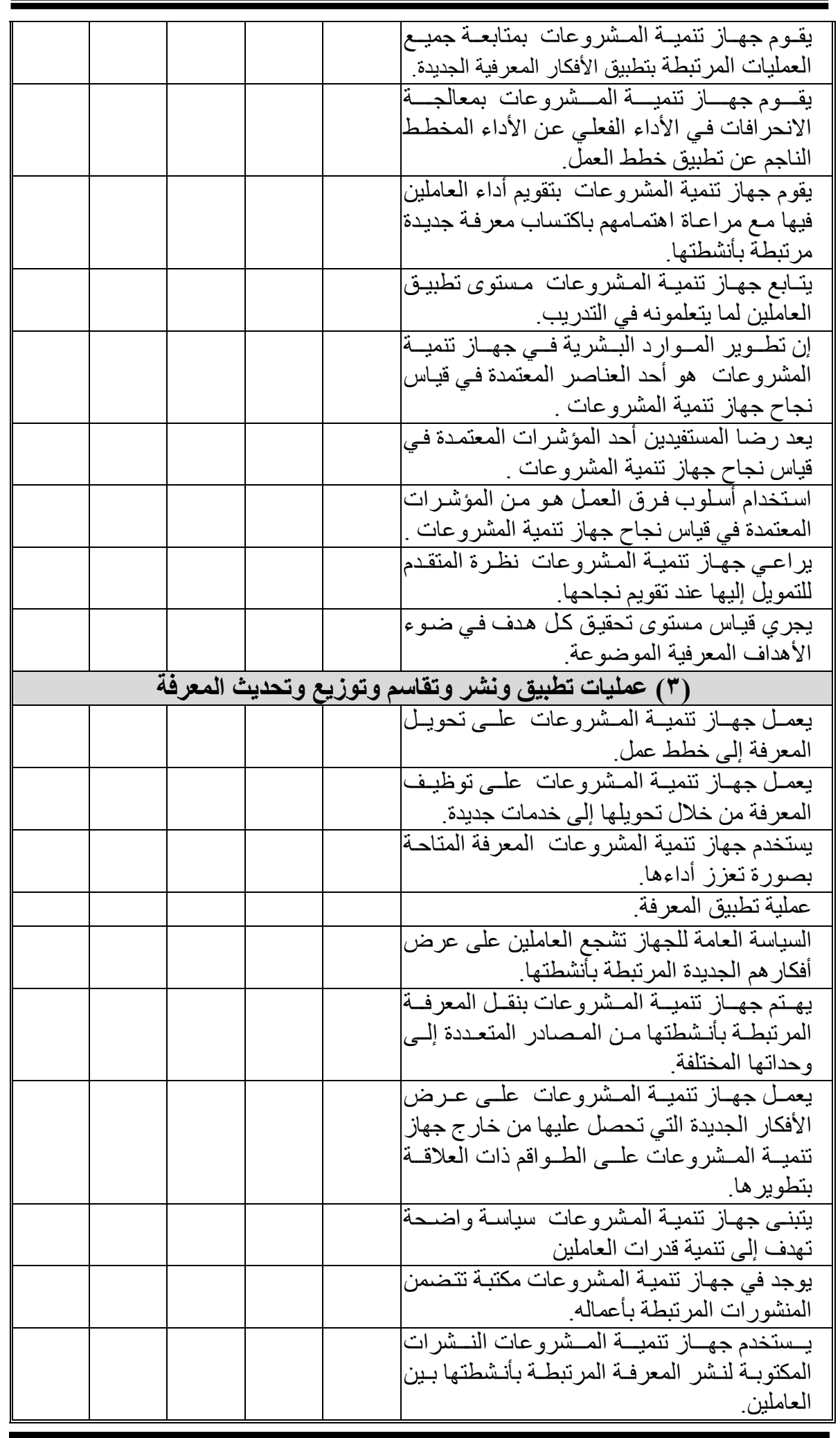




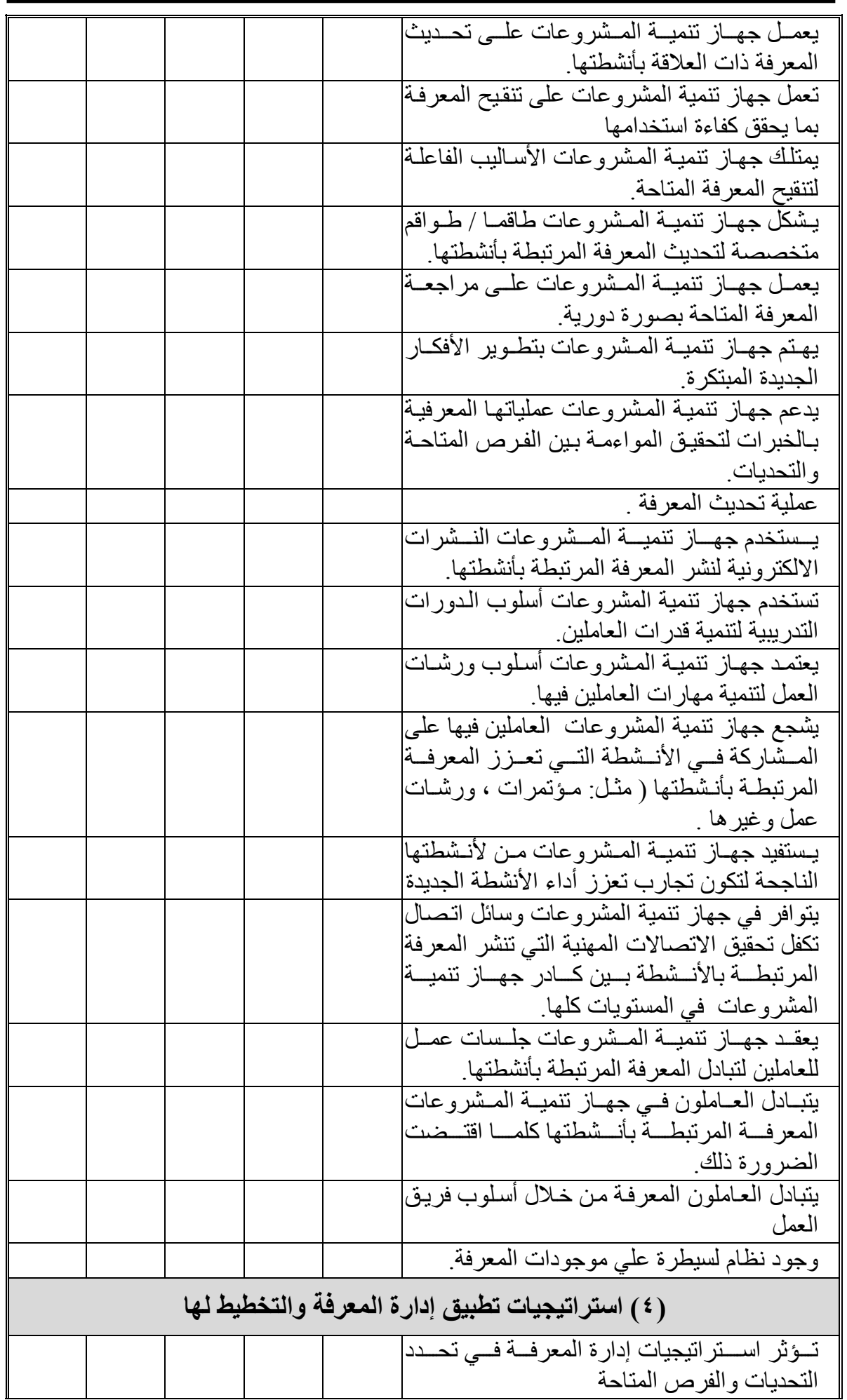




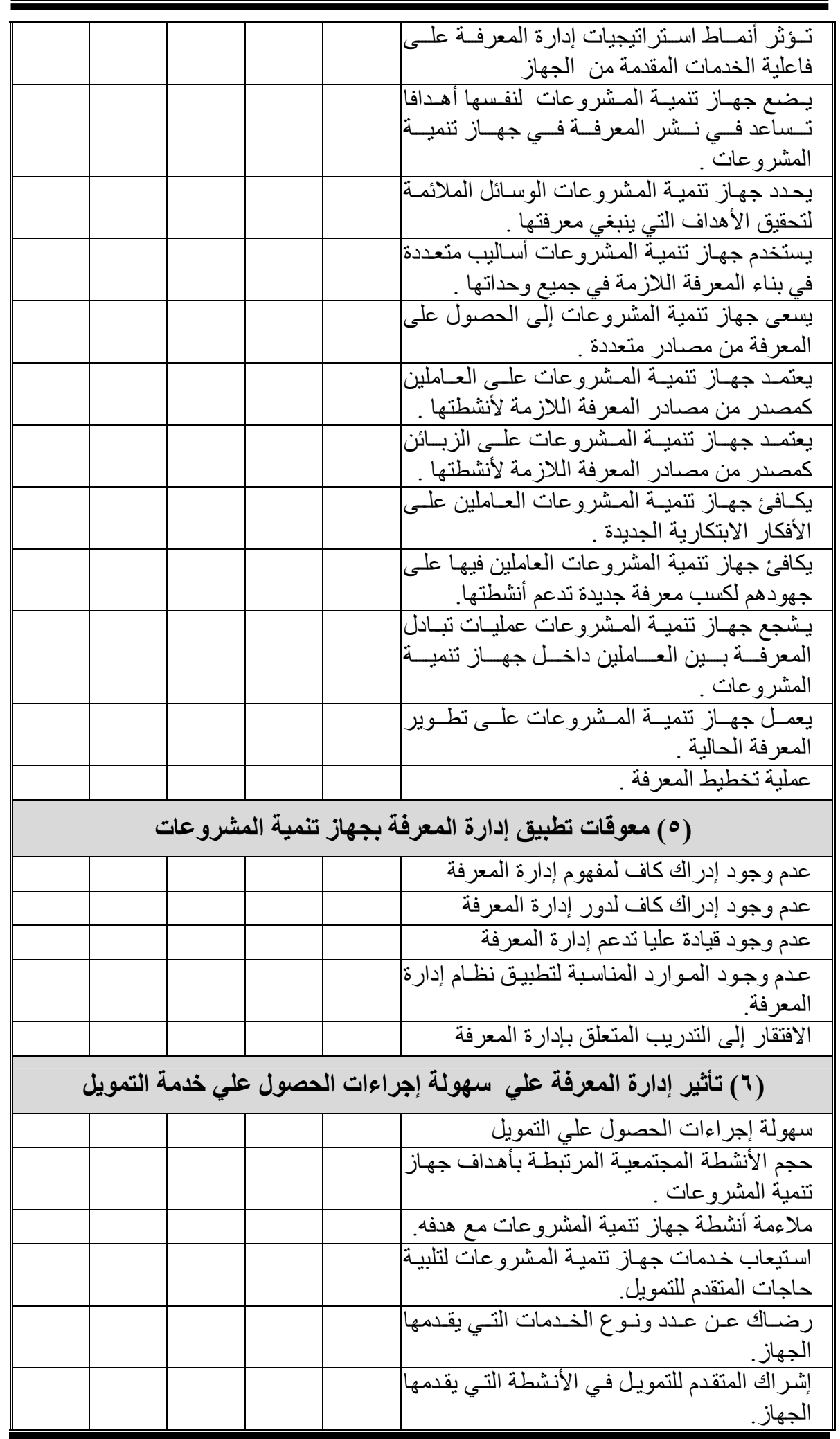




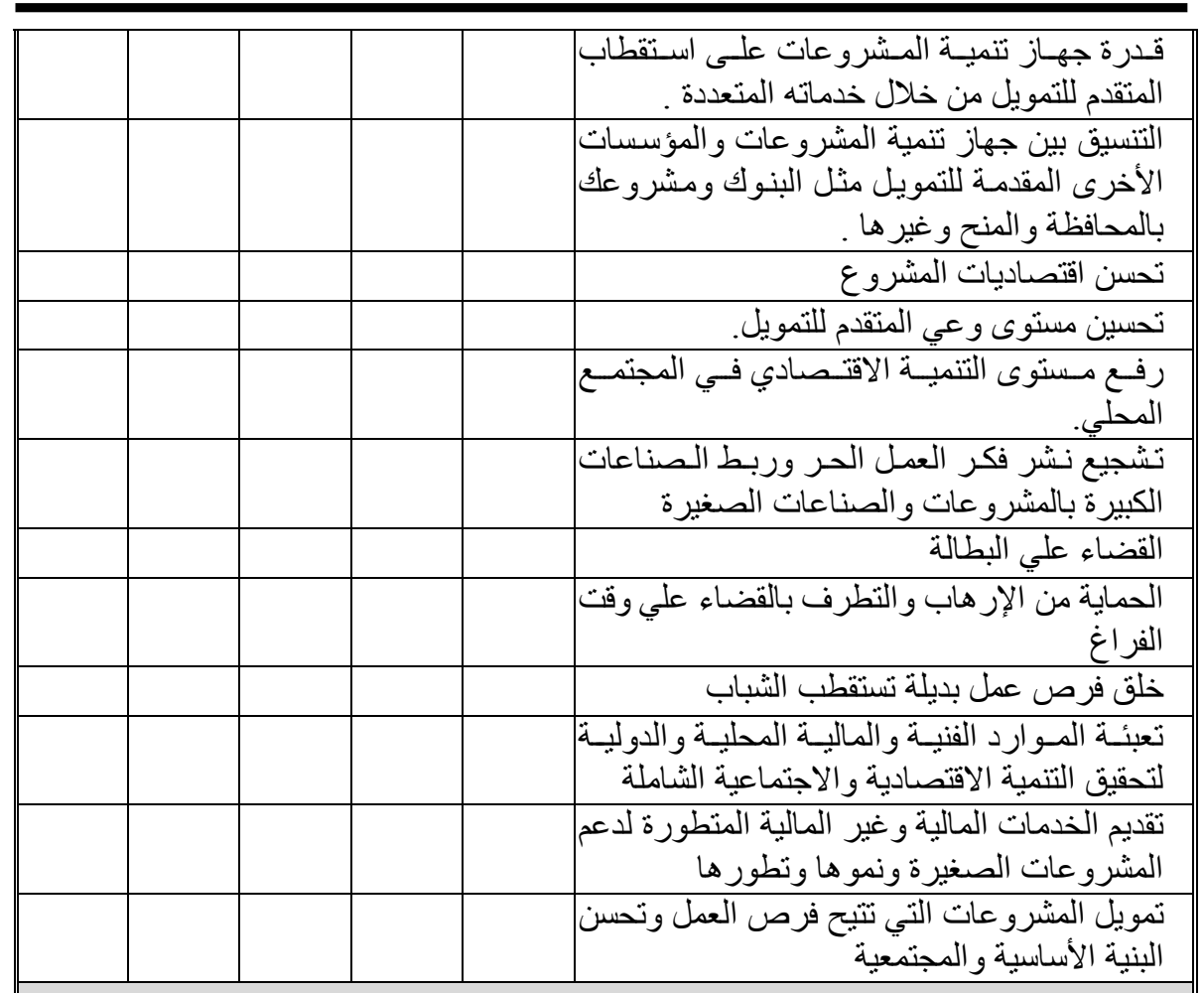

تأثير تطبيقات إدارة المعرفة علي تحسين خدمة التدريب لجهاز تتمية المشروعات الصغيرة (V)

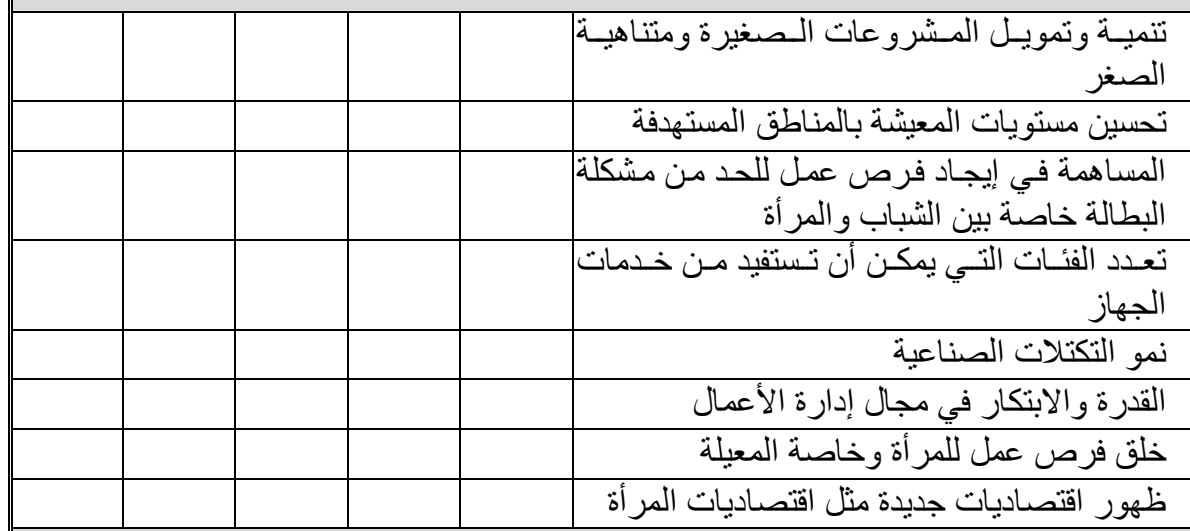

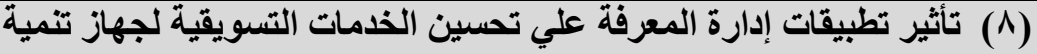

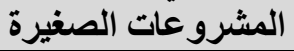

\begin{tabular}{|l|l|l|l|r|r||}
\hline & & & & \\
\hline & & & & \\
\hline & & & \\
\hline & & & & \\
\hline & & & \\
\hline
\end{tabular}




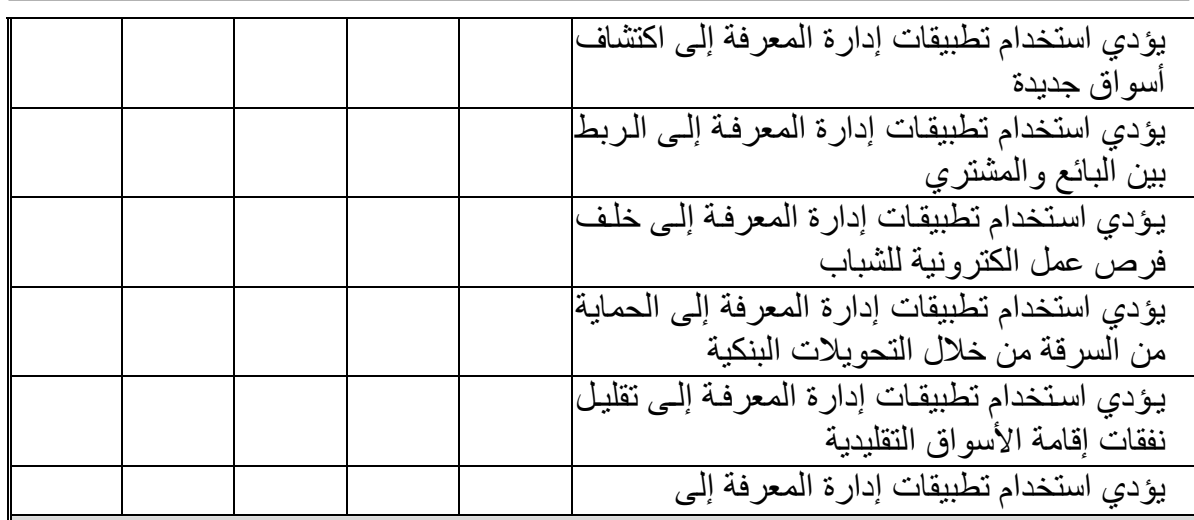

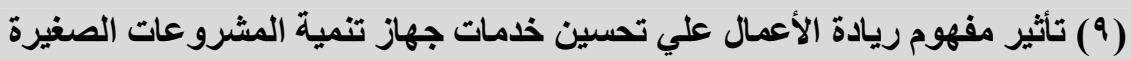

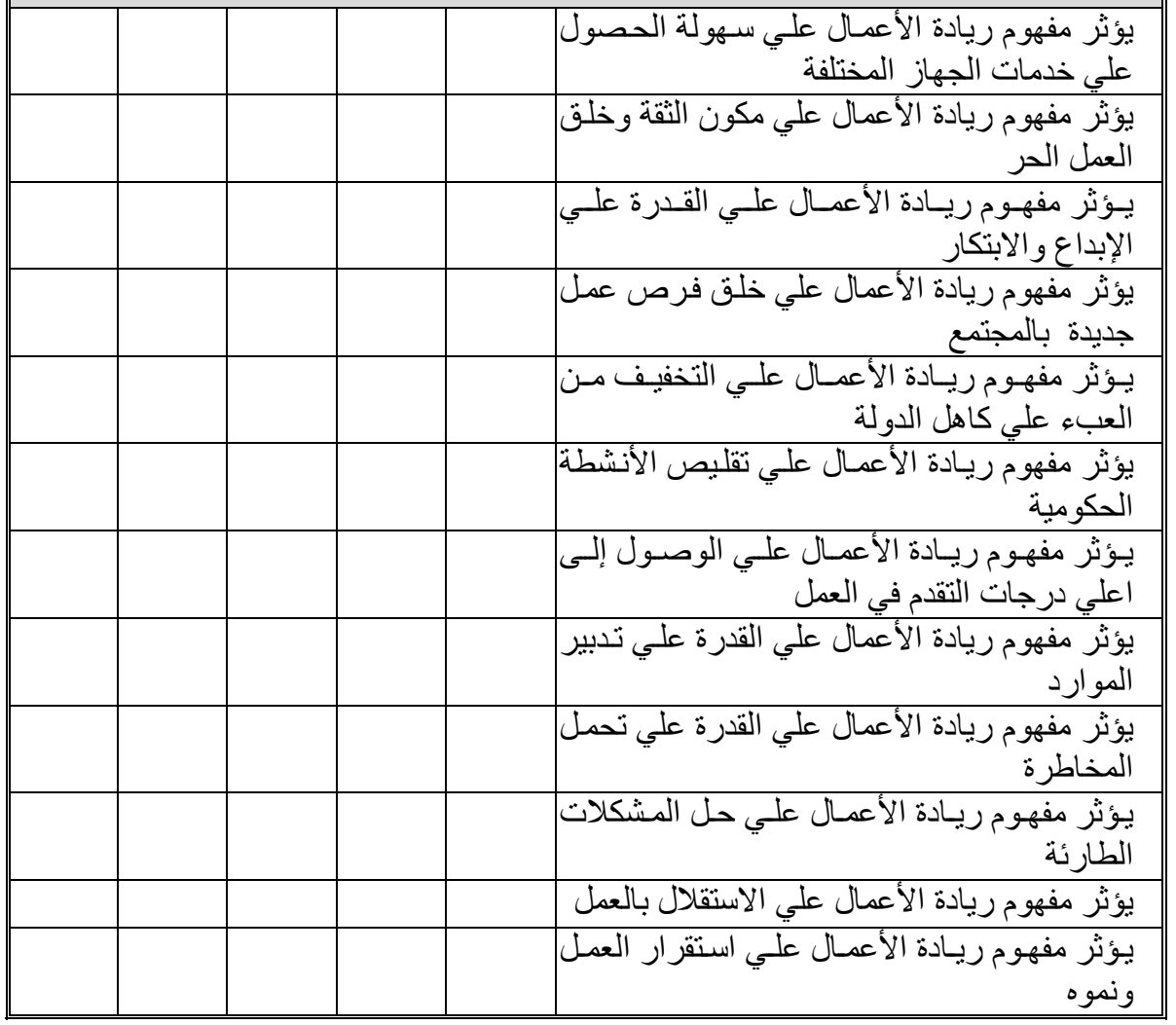

